UNIVERSIDADE DE SÃO PAULO

FACULDADE DE FILOSOFIA, LETRAS E CIÊNCIAS HUMANAS

Ingrid Campos Nardeli

O PROCESSO DE AQUISIÇÃO/APRENDIZAGEM DE PASSATO

PROSSIMO E IMPERFETTO POR APRENDIZES BRASILEIROS EM CONTEXTO DE INSTRUÇÃO FORMAL

São Paulo

2012

Versão corrigida 
Ingrid Campos Nardeli

\section{O PROCESSO DE AQUISIÇÃO/APRENDIZAGEM DE PASSATO PROSSIMO E IMPERFETTO POR APRENDIZES BRASILEIROS EM CONTEXTO DE INSTRUÇÃO FORMAL}

Dissertação apresentada ao Programa de Língua, Literatura e Cultura Italianas, Faculdade de Fisosofia Letras e Ciências Humanas, Universidade de São Paulo, para a obtenção do título de Mestre em Letras.

Orientadora: Prof ${ }^{\mathrm{a}} \mathrm{Dr}^{\mathrm{a}}$ Elisabetta A. R. M. C. Santoro

São Paulo

2012

Versão corrigida 


\section{Agradecimentos}

A Deus por sempre me dar oportunidades;

aos meus pais por me incentivarem e oferecerem o abraço necessário incondicionalmente e sempre;

ao meu namorado, noivo e marido que viveu comigo, em toda intensidade, esse processo;

a minha família pelo apoio constante;

a minha orientadora, Dra. Elisabetta Santoro, por ter me conduzido e me ensinado a amar tanto a língua italiana quanto o prazer de pesquisar;

aos amigos que, de perto ou de longe, torceram e acreditaram na realização desse trabalho;

aos meus alunos que me estimularam tanto e sem os quais a pesquisa não teria sido realizada;

a todos aqueles que me ofereceram a compreensão, o suporte e o carinho;

àqueles que me mostraram um novo horizonte quando tudo parecido ter chegado ao fim. 


\section{Resumo}

NARDELI, Ingrid C. O PROCESSO DE AQUISIÇÃO/APRENDIZAGEM DE PASSATO PROSSIMO E IMPERFETTO POR APRENDIZES BRASILEIROS EM CONTEXTO DE INSTRUÇÃO FORMAL. 2012. 172 f. Dissertação (Mestrado) Faculdade de Filosofia, Letras e Ciências Humanas, Universidade de São Paulo, São Paulo, 2012.

A partir do século XX, iniciaram-se os estudos sistemáticos sobre a aquisição/aprendizagem de segundas línguas assim como a observação e elaboração de métodos mais eficazes no ensino da L2. Este trabalho teve sua origem no interesse pela investigação da aquisição/aprendizagem dos verbos ditos do passado da língua italiana, passato prossimo e imperfetto por aprendizes brasileiros em contexto de instrução formal. Através da realização de uma pesquisa longitudinal, os alunos dos níveis II, III, IV e V dos cursos de Italiano no Campus, oferecidos pelo departamento de Letras Modernas da Universidade de São Paulo, foram submetidos a testes de dois tipos: produção de texto e de cloze. Os testes foram realizados em vários momentos do processo de aquisição da L2, tanto antes da aprendizagem explícita quanto depois. O primeiro objetivo era descobrir quais os efeitos das instruções explícitas e implícitas no aprendizado desses dois tempos verbais a curto e a longo prazo. O segundo objetivo consistia em investigar se no processo de aquisição/aprendizagem da L2 os aprendizes associavam os predicados télicos às marcas perfectivas e os predicados atélicos às marcas imperfectivas. Partindo dos pressupostos teóricos sobre aquisição/aprendizagem da L2 e ainda da análise do material didático utilizado pelos aprendizes, foram elaboradas hipóteses que pudessem explicar os resultados alcançados na pesquisa. Os verbos télicos foram associados primeiro à marca perfectiva, conforme algumas teorias já haviam pressuposto. Entretanto, através dos dados obtidos não foi possível verificar se, de fato, os verbos atélicos são associados diretamente à marca imperfectiva nos primeiros estágios da aquisição. Os dados fornecidos pela produção de texto indicaram 
que os alunos não utilizam o passato prossimo em seguida à instrução formal, visto que as produções consistiram, principalmente, na utilização do tempo presente. Houve ocorrências consideráveis de verbos no presente nos níveis II e IV, o que não aconteceu no nível III, em que os alunos utilizaram mais o passato prossimo. Pode-se observar uma oscilação de uso da marca perfectiva dependendo do nível que os alunos cursavam, fato que pode ser explicado pelas atividades presentes/ausentes no livro didático. Em relação ao teste de cloze, verificou-se que os alunos em seguida ao aprendizado explícito do passato prossimo, nível II, já o utilizaram no exercício. Esse fato pode, talvez, ser associado ao tipo de atividade proposta no material didático em que havia muitas atividades de cloze e transformação de frases, mas poucos que se relacionavam à produção de texto livre.

Palavras-chave: aquisição/aprendizagem de L2, instrução explícita e implícita, verbos, tempos verbais, material didático. 


\begin{abstract}
NARDELI, Ingrid C. - THE ACQUISITION / LEARNING PROCESS OF PASSATO PROSSIMO and IMPERFETTO FOR BRAZILIAN LEARNERS IN THE CONTEXT OF FORMAL EDUCATION. 2012. 172 f. Thesis (Master's Degree) - Faculdade de Filosofia, Letras e Ciências Humanas, Universidade de São Paulo, São Paulo, 2012.
\end{abstract}

From the twentieth century, systematic studies on the acquisition / learning of second languages began, as well as the observation and development of more effective methods in teaching L2. This work had its origin in research interest in acquisition / learning of verbs in past tense of the Italian language, passato prossimo and imperfetto, by Brazilian learners in the context of formal education. By carrying out a longitudinal study of the Italian courses in the Campus offered by the Department of Modern Languages and Literature at the University of São Paulo, the students in levels II, III, IV and $\mathrm{V}$ performed two types of tests: production of text and cloze. The tests were conducted at various times of the L2 acquisition process, both before and after explicit learning. The first goal was to find out the effects of explicit and implicit instructions in the learning of these two tenses, in short and long term. The second goal was to investigate whether, in the process of acquisition / learning of L2, the learners associate telic predicates to perfective marks and atelic predicates to imperfective marks. Based on theoretical assumptions about acquisition / learning of L2 and also on analysis of teaching material used by the learners, hypotheses that could explain the results achieved in the research were developed. Telic verbs were first associated to the perfective mark, as some theories had assumed. However, it could not be verified by the data obtained if, indeed, the atelic verbs are directly associated with the imperfective mark in the early stages of acquisition. Data provided by the production of text indicated that students do not use passato prossimo after the formal education, since the productions consisted mainly in using the present tense. There was considerable 
occurrences of present tense verbs in levels II and IV, but not for level III, in which students used more often the passato prossimo. One can observe an oscillation of use of the perfective mark depending on the level that students were attending, which may be explained by the activities present / absent in the textbook. Regarding the cloze test, it was found that students, after the explicit learning of the passato prossimo, in level II, already used passato prossimo in the exercise. This fact may perhaps be associated with the type of activity proposed in the teaching materials, containing many cloze and sentence transformation activities, but few activities related to the production of free text.

Keywords: acquisition / learning of L2, implicit and explicit instruction, verbs, tenses, teaching material. 


\section{Sumário}

Introdução ............................................................................................ 13

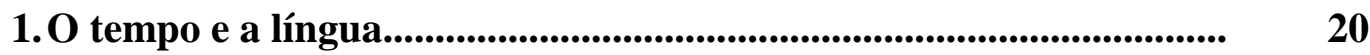

1.1 O sistema dos tempos verbais na língua italiana........................ 20

1.2 A aquisição do sistema verbal da língua italiana........................ 35

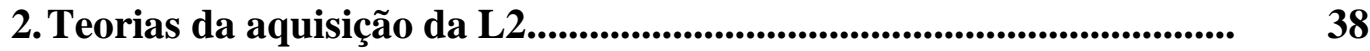

2.1 Os fatores internos e externos na aquisição da L2 …................ 39

2.2 Das disciplinas Aquisição de segundas línguas e Didática da L2 42

$2.3 \quad$ Krashen e o modelo do monitor................................................ 44

$2.4 \quad$ A hipótese do output .......................................................... 48

2.5 A hipótese da interação (Interaction Hypothesis).................... 53

2.6 A aprendizagem implícita e explícita em L2 .......................... 58

3. Instruções explícitas: o material didático............................................. 66

3.1 Linea Diretta - análise de um livro didático............................ 71

3.3.1 Passato prossimo e imperfetto no livro didático .................. $\quad 76$

4. O passato prossimo e o imperfetto nas produções dos aprendizes ...... $\quad 101$

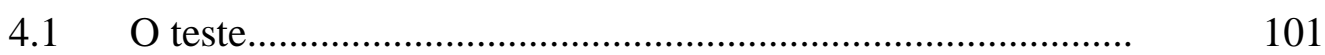

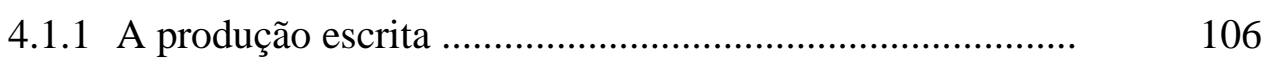

4.1.2 O cloze ........................................................................... 109

4.2 Os participantes................................................................ 110

4.3 Tabulação e análise dos dados da produção escrita ................ 113

4.3.1 Os resultados da produção escrita ...................................... 134

4.4 Tabulação e análise dos dados do cloze .................................. 139

4.4.1 Os resultados do cloze ...................................................... 157

4.5 Relações entre os resultados obtidos .................................... 158

Considerações finais ..................................................................................................... 162

Referências bibliográficas .......................................................................................... 166

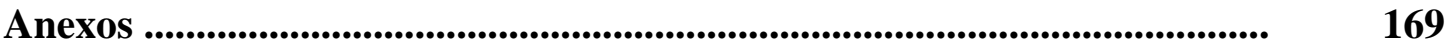


Lista de gráficos

Gráfico 1 - Idade dos participantes............................................................... 112

Gráfico 2 - Profissão dos participantes............................................................ 112

Gráfico 3 - Escolaridade dos participantes .............................................................. 112

Gráfico 4 - Idiomas falados pelos participantes................................................... 112

Gráfico 5 - Tempo de estudo .................................................................... 113

Gráfico 6 - Estudo da língua italiana ................................................................. 113

Gráfico 7 - Origem ............................................................................................. 113

Gráfico 8 - Viagem à Itália .................................................................... 113

Gráfico 9 - Motivo de estudo da língua....................................................... 113

Gráfico 10 - Contato com a língua italiana ......................................................... 113

Gráfico 11 - Leitura em língua italiana........................................................... 113

Gráfico 12 - Verbo vedere .......................................................................... 114

Gráfico 13 - Verbo camminare ..................................................................... 116

Gráfico 14 - Verbo pedalare....................................................................... 118

Gráfico 15 - Verbo esserci............................................................................ 120

Gráfico 16 - Verbo continuare..................................................................... 122

Gráfico 17 - Verbo essere............................................................................... 124

Gráfico 18 - Verbo cadere ......................................................................... 126

Gráfico 19 - Verbo aprire ........................................................................... 127

Gráfico 20 - Verbo lanciare ......................................................................... 128

Gráfico 21 - Verbo scoprire...................................................................... 130

Gráfico 22 - Verbo arrivare .......................................................................... 131

Gráfico 23 - Verbo trovare..................................................................... 133

Gráfico 24 - Verbo partire .............................................................................. 139

Gráfico 25 - Verbo arrivare.................................................................................. 140

Gráfico 26 - Verbo riuscire....................................................................... 141

Gráfico 27 - Verbo prendere................................................................................ 142

Gráfico 28 - Verbo mettermi...................................................................... 143

Gráfico 29 - Verbo capirsi........................................................................ 144

Gráfico 30 - Verbo trovare .......................................................................... 145

Gráfico 31 - Verbo visitare ........................................................................... 146

Gráfico 32 - Verbo essere......................................................................... 147 
Gráfico 33 - Verbo preferire........................................................... 148

Gráfico 34 - Verbo durare ....................................................................... 149

Gráfico 35 - Verbo sentirsi.............................................................. 150

Gráfico 36 - Verbo esserci............................................................... 151

Gráfico 37 - Verbo esserci II.............................................................. 153

Gráfico 38 - Verbo provare................................................................. 154

Gráfico 39 - Verbo parlare ......................................................................

Gráfico 40 - Verbo sorvolare................................................................ 156 
Lista de quadros

Quadro 1 - Ensino explícito e implícito................................................................

Quadro 2 - Manual para professores............................................................... $\quad 72$

Quadro 3 - Livro Linea Diretta.................................................................. $\quad 75$

Quadro 4 - O passato prossimo........................................................................... 77

Quadro 5 - Compreensão de áudio............................................................................... $\quad 78$

Quadro 6 - Estrutura......................................................................................... 79

Quadro 7 - Atividade de passato prossimo - exemplo..................................... 80

Quadro 8 - Atividade de passato prossimo......................................................... 80

Quadro 9 - Atividade oral............................................................................. 81

Quadro 10 - Atividade escrita........................................................................ 81

Quadro 11 - Compreensão textual....................................................................... 82

Quadro 12 - Propostas de produções: oral e escrita.......................................... 83

Quadro 13 - Preenchimento de espaços........................................................................ 85

Quadro 14 - Estrutura do passato prossimo..................................................... 86

Quadro 15 - O imperfetto............................................................................ 88

Quadro 16 - A compreensão auditiva - imperfetto........................................ 89

Quadro 17 - Diálogo................................................................................................ 90

Quadro 18 - Diálogo em duplas............................................................................ 91

Quadro 19 - Estrutura do imperfetto............................................................. 91

Quadro 20 - Uso do passato prossimo e imperfetto............................................... $\quad 92$

Quadro 21 - Atividade de pergunta e resposta................................................... $\quad 92$

Quadro 22 - Preenchimento de frases................................................................ $\quad 92$

Quadro 23 - Tipos de ação.................................................................................. 96

Quadro 24 - Retomada de tempos verbais.................................................... 98

Quadro 25 - Combinação de passato prossimo e imperfetto............................ 99 
Lista de tabelas

Tabela 1 - Cursos extracurriculares e o material didático.......................... $\quad 75$

Tabela 2 - Aplicação dos testes.............................................................................. 105

Tabela 3 - Desvio padrão do verbo vedere.................................................... 114

Tabela 4 - Desvio padrão do verbo camminare.............................................. 116

Tabela 5 - Desvio padrão do verbo pedalare................................................ 118

Tabela 6 - Desvio padrão do verbo esserci...................................................... 120

Tabela 7 - Desvio padrão do verbo continuare................................................. 122

Tabela 8 - Desvio padrão do verbo essere.................................................... 124

Tabela 9 - Desvio padrão do verbo cadere............................................................ 126

Tabela 10 - Desvio padrão do verbo aprire .................................................. 127

Tabela 11 - Desvio padrão do verbo lanciare .................................................... 128

Tabela 12 - Desvio padrão do verbo scoprire ......................................................... 130

Tabela 13 - Desvio padrão do verbo arrivare ................................................. 131

Tabela 14 - Desvio padrão do verbo trovare ......................................................... 133

Tabela 15 - Desvio padrão do verbo partire ................................................... 139

Tabela 16 - Desvio padrão do verbo arrivare ...................................................... 140

Tabela 17 - Desvio padrão do verbo riuscire...................................................... 141

Tabela 18 - Desvio padrão do verbo prendere .................................................. 142

Tabela 19 - Desvio padrão do verbo mettermi...................................................... 143

Tabela 20 - Desvio padrão do verbo capirsi.................................................... 144

Tabela 21 - Desvio padrão do verbo trovare ...................................................... 145

Tabela 22 - Desvio padrão do verbo visitare................................................. 146

Tabela 23 - Desvio padrão do verbo essere ......................................................... 147

Tabela 24 - Desvio padrão do verbo preferire ................................................. 148

Tabela 25 - Desvio padrão do verbo durare ....................................................... 149

Tabela 26 - Desvio padrão do verbo sentirsi.......................................................... 150

Tabela 27 - Desvio padrão do verbo esserci.................................................. 151

Tabela 28 - Desvio padrão do verbo esserci II .................................................. 153

Tabela 29 - Desvio padrão do verbo provare................................................. 154

Tabela 30 - Desvio padrão do verbo parlare ................................................ 155

Tabela 31 - Desvio padrão do verbo sorvolare.................................................... 156 


\section{Introdução}

Durante o percurso realizado na aquisição da língua italiana em contexto de instrução formal, ao estudar o sistema dos tempos verbais, sua complexidade e efeitos produzidos no discurso, percebi a sua crucialidade na constituição do enunciado e tal processo me fez compreender melhor até mesmo o português, a minha língua materna.

Ainda na graduação, deparei-me com a dificuldade de combinar os tempos verbais e usá-los corretamente, aproximando-me da língua falada por um nativo e desfrutando das possibilidades que a língua italiana me oferecia na construção das produções orais ou escritas. Essa dificuldade existia ainda quando algumas estruturas linguísticas já haviam sido abordadas explicitamente em sala de aula.

Após o término da graduação, diante da vontade de continuar estudando a língua italiana, perguntei-me qual era o tema que havia gerado questões durante a aquisição da L2. A partir da leitura de alguns livros sobre pesquisas concernentes à aquisição da língua italiana por não nativos e depois de longas reflexões conduzidas pela minha professora e orientadora, decidimos realizar uma pesquisa que observasse a aquisição do italiano por brasileiros e, mais especificamente, do sistema verbal.

A aquisição/aprendizagem dos tempos verbais de uma língua é sempre fundamental, se caracterizarmos que todo enunciado se estrutura a partir dos verbos e que são eles, portanto, o núcleo do predicado, pois transmitem as noções de tempo, modo, aspecto, pessoa, número e gênero e são semanticamente caracterizados por descrever atividades, estados ou eventos. No ato da produção de um enunciado em qualquer língua, o falante instaura um sujeito, que é tomado como ponto de referência e do qual dependem o tempo e o espaço. A partir do eu estabelecido no enunciado, 
estabelece-se um eixo coordenador da categoria de concomitância e de não concomitância que, por sua vez, divide-se em anterioridade e posterioridade, criando três momentos de referência chamados de presente, passado e futuro.

O tempo linguístico é determinado por esse momento de referência, pelo momento do acontecimento e pelo momento da enunciação, a partir dos quais é formado todo o sistema dos tempos verbais de uma língua.

Em se tratando de um sistema vasto e complexo, no presente trabalho, escolhemos fazer um recorte da questão do tempo na língua e optamos por estudar dois tempos verbais que marcam ações no passado, caracterizadas por indicarem aspectos distintos em língua italiana: o passato prossimo e o imperfetto.

Partindo desse recorte e considerando que o trabalho pretende estudar a aquisição desses dois tempos verbais da língua italiana por aprendizes brasileiros e que, portanto, se coloca no âmbito dos estudos de aquisição de segundas línguas (Second Language Acquisition) cabe buscar definições e escolher lexemas adequados que serão utilizados no decorrer do trabalho.

Rod Ellis (1997: 3) afirma que o conceito de segunda língua se refere a qualquer língua aprendida depois da primeira ou materna e não se opõe ao conceito de língua estrangeira, pois nessa concepção ambas são consideradas segundas línguas e, de maneira geral, tanto a aprendizagem de uma língua no contexto onde é utilizada pelos falantes mesmo que seja fora do ambiente de instrução formal, por exemplo, em um programa de imersão, quanto uma língua estrangeira, que é adquirida fora do contexto em que é habitualmente falada, tratam de uma língua "posterior" à materna, logo segunda língua. O autor propõe a definição “A aquisição da segunda língua, então, pode ser definida como o percurso em que pessoas aprendem uma língua além da língua 
materna, dentro ou fora da sala de aula" (ELLIS, 1997: 3) ${ }^{1}$. Sabemos que existem características comuns e distintas entre a língua estrangeira e a L2, porém, essas peculiaridades não são essenciais para o estudo e a compreensão de determinados fenômenos, como é o caso do nosso trabalho. Escolhemos, portanto, usar sempre L2 para indicar a língua não materna.

Definida a questão da segunda língua, precisamos acrescentar uma reflexão sobre o processo de aquisição/aprendizagem da L2, no qual intervêm fatores internos e externos, relacionados tanto ao ambiente em que se dá a aprendizagem quanto às capacidades cognitivas do aprendiz que facilitam ou inibem a aquisição da L2. Esses elementos são frutos de descobertas e hipóteses de diversos autores que buscaram compreender o funcionamento e o processo de aquisição da língua alvo bem como elaborar métodos e abordagens ${ }^{2}$ que visassem ao ensino mais eficaz.

Entre eles, em especial, mencionamos o papel da aprendizagem implícita e explícita, pois essas propostas estão relacionadas aos efeitos que a instrução confere ao processo de aprendizagem. Algumas hipóteses sustentam a instrução explícita como facilitadora e, outras, refutando essa convicção, postulam que o conhecimento

\footnotetext{
1 "'L2 acquisition', then can be defined as the way in which people learn a language other than their mother tongue, inside or outside of a classroom." Todas as traduções, do inglês e do italiano, presentes nesta dissertação são de minha autoria.

${ }^{2}$ No presente trabalho, são consideradas as definições de metodologia, abordagem e método propostas por Almeida Filho (2005). Segundo o autor, "compreende-se por metodologia a pedagogia de ensino de língua(s), ou seja, um conjunto de procedimentos recomendáveis para bem ensinar uma língua e que são explicados por um feixe de pressupostos" (2005: 63), o que, por sua vez, difere de abordagem, pois esta é "um conjunto potencial de crenças, conceitos, pressupostos e princípios que orientam e explicam (a metodologia) não só as experiências diretas com e na língua alvo (o método) em salas de aulas mas também as outras dimensões do processo complexo (a operação) de ensinar uma língua, a saber, o planejamento curricular e/ou de programas específicos, os materiais de ensino, e a avaliação do próprio processo e de seus agentes". (2005: 63). No nível da abordagem são definidas coordenadas a partir das quais são propostos métodos que busquem atingir os objetivos propostos. Segundo Balboni (1994: 49), a abordagem é fundamentada em uma teoria, apresenta coerência interna e possibilita a geração de métodos capazes de realizar a própria abordagem.
} 
consciente da língua pode gerar lacunas entre aquilo que o falante sabe sobre ela e aquilo que, de fato, usa.

Ainda envolvendo questões relacionadas à aquisição, especificamente, tempos linguísticos ditos do passado da língua italiana, autores como Banfi e Bernini (2003) e Andersen e Shirai (1996) afirmaram existir uma tendência em relacionar o aspecto verbal ao tipo de predicado, isto é, nos estágios iniciais da aquisição, a marca perfectiva, que em língua italiana é expressa através do passato prossimo, seria associada aos verbos télicos e, por outro lado, a marca imperfectiva, realizada no discurso pelo imperfetto, apresentaria a tendência de se associar aos verbos atélicos.

Partindo desses pressupostos e visando a refletir sobre a questão da aquisição/aprendizagem do passato prossimo e imperfetto da língua italiana, estabelecemos as seguintes perguntas de pesquisa:

1. após a exposição à instrução formal explícita do passato prossimo, o aprendiz introduz a estrutura imediatamente na sua produção? E, em caso afirmativo, em que medida?

2. antes de ter recebido instruções explícitas sobre o imperfetto, é possível verificar a tendência dos aprendizes brasileiros a usá-lo quando se faz necessário expressar uma ação durativa, não limitada, estática e inacabada?

3. é evidente o efeito das instruções explícitas a curto prazo? Esse efeito permanece em momentos posteriores e mais distantes da instrução formal?

4. é possível afirmar que no contexto em que foi realizada a pesquisa houve por parte dos alunos a tendência a associarem as marcas perfectivas aos verbos télicos e as imperfectivas, por sua vez, aos atélicos? 
Para esse fim, escolhemos realizar uma pesquisa longitudinal com alunos de língua italiana dos cursos extracurriculares organizados pela Área de Língua e Literatura Italiana do Departamento de Letras Modernas, FFLCH - USP, chamados Italiano no Campus. Os cursos de Italiano no Campus são oferecidos para a comunidade universitária como um todo e também para a comunidade externa. São, portanto, pensados para um público não especializado, que deseja estudar a língua e aprender sobre a cultura da Itália com finalidades não específicas. Os cursos recebem desde alunos da habilitação em língua e literatura italiana do curso de Letras da USP, até pessoas externas e sem nenhuma ligação com a universidade, passando por alunos da Faculdade de Filosofia, Letras e Ciências Humanas, alunos de outras faculdades, funcionários da USP, etc. Os professores são alunos que terminaram a graduação, não necessariamente em Letras, mas que falam fluentemente a língua italiana e estão ligados à Universidade de São Paulo, cursando ou licenciatura, ou ainda, a pós-graduação.

A pesquisa consistiu na aplicação de testes nos níveis de II a V do percurso de aquisição. O teste foi composto por uma produção escrita livre baseada na reprodução de um trecho de um filme italiano e por um exercício, no qual os aprendizes precisavam preencher os espaços vazios de um texto com os verbos conjugados nos tempos que consideravam adequados (cloze). Analisamos quantitativamente os dados que resultaram dos testes realizados para verificar como foram usados por alunos dos diferentes níveis os tempos verbais passato prossimo e imperfetto. A partir dos traços de + ou - telicidade e da sua recorrência mais restrita ou mais difundida, passamos à análise dos dados, com o objetivo de responder as perguntas de pesquisa e promover a reflexão sobre como acontece a aquisição de passato prossimo e imperfetto por aprendizes brasileiro nesse contexto. 
O trabalho foi dividido em quatro capítulos, cujos conteúdos são descritos no plano da dissertação abaixo:

1. o primeiro capítulo apresenta o sistema dos tempos verbais da língua italiana, com base em esquemas que levam a compreender os sistemas enunciativo e enuncivo e fornece uma descrição dos tempos verbais, da sua formação e do seu uso, aprofundando-se, em especial, na questão da aquisição desse sistema, sobretudo, do passato prossimo e do imperfetto, através de teorias relacionadas ao aspecto verbal;

2. o segundo capítulo traz a fundamentação teórica e se concentra nas teorias de aquisição de L2, explanando hipóteses muito discutidas como a do input, do output $^{3}$, da interação e, mais especificamente, estabelecendo diferenças entre a aprendizagem explícita e implícita;

3. no terceiro capítulo são estabelecidos critérios de avaliação dos materiais didáticos de L2, utilizados, na segunda seção do capítulo, para descrever e tecer comentários sobre a apresentação de passato prossimo e imperfetto no material didático adotado nos cursos do Italiano no Campus - o livro Linea Diretta;

4. o quarto capítulo apresenta os dados gerais da tabulação de dados, bem como a análise específica dos resultados obtidos nos diferentes níveis do curso. Nessa

\footnotetext{
${ }^{3}$ Optamos por manter o lexema input mesmo sabendo que a tradução geralmente utilizada em português é insumo. Uma das referências é o Glossário de Linguística Aplicada, desenvolvido na UnB sob a supervisão do Prof. Dr. José Carlos Paes de Almeida Filho, que elaborou o seguinte conceito de insumo: "Toda manifestação de linguagem na língua-alvo que pode, eventualmente, se tornar competência comunicativa na interlíngua. $\mathrm{O}$ insumo tem de ser recebido por um filtro afetivo favorável para que tenha chance de se converter em competência adquirida. Não deve ainda ser gramaticalmente sequenciado e precisa ser de interesse ou relevante ao aprendente. O insumo pode ser produzido entre os participantes ou trazido pronto para a sala de aula." Nossa escolha de manter o termo em inglês deve-se ao seu recorrente uso em inglês nas obras consultadas, nas quais indica toda e qualquer amostra da L2 a que o aprendiz está exposto. Seguindo o mesmo critério, ao invés de utilizar "insumo produzido", tradução proposta pelo Glossário Sala, adotamos o lexema em inglês, output, que se refere a toda produção escrita ou oral do aprendiz de uma L2. As definições citadas de insumo e insumo produzido encontram-se no seguinte endereço eletrônico: http://www.sala.org.br/i/ (último acesso 30/12/11).
} 
seção são realizadas também comparações entre os dados obtidos e são formuladas hipóteses possíveis que justifiquem os resultados.

A dissertação se encerra com as considerações finais em que são retomados os objetivos que guiaram a pesquisa e em que buscamos responder as perguntas de pesquisa. 


\section{O tempo e a língua}

O tempo linguístico expresso pelo verbo é diferente do tempo físico (BENVENISTE, 1974: 73). O primeiro é o sistema de relações temporais que são transmitidas pelos signos linguísticos, enquanto o segundo pode ser medido e se relaciona aos acontecimentos do mundo externo. No processo da enunciação, na emissão de uma mensagem, estabelece-se um eixo a partir do qual é gerado um antes e um depois. O tempo linguístico, conforme afirma Bertinetto (1991), situa os eventos segundo uma ideia de antes, durante e depois e os tempos verbais cristalizam, através do paradigma morfológico, opções fundamentais que dizem respeito a possíveis conceitos do desenvolvimento cronológico dos eventos.

\subsection{O sistema dos tempos verbais na língua italiana}

No que concerne à morfologia, os verbos do italiano apresentam uma estrutura regular, pois são formados por três conjugações, a saber: a primeira terminada em -are, como nos verbos cantare (cantar), mangiare (comer), ballare (dançar); a segunda terminada em -ere, como em credere (crer), vedere (ver), leggere (ler); a terceira terminada em -ire, como em salire (subir), partire (partir), capire (entender). A partir da forma-base do verbo é possível chegar ao paradigma completo; entretanto, vale salientar, que esse fenômeno ocorre na maioria, mas não em todos os verbos. $\mathrm{O}$ verbo 
andare (ir) seria um dos exemplos dos verbos ditos irregulares, já que sua conjugação não segue o padrão do paradigma verbal.

O italiano utiliza sufixos adicionados à raiz verbal ou auxiliares para marcar as categorias de tempo, modo, aspecto e diátese. As categorias de pessoa e número são projetadas pelo sujeito e se refletem na concordância entre ele e o verbo.

Por outro lado, as categorias de tempo, modo, aspecto, diátese e suas relações são expressas através da organização do sistema verbal.

Vejamos agora como são organizadas essas relações. Ao produzir um enunciado, o falante instaura um sujeito, que é tomado como ponto de referência e do qual dependem o tempo e o espaço. Essas categorias são conhecidas como ego (eu), hic (aqui), nunc (agora) e Benveniste (1974: 74) as usa para mostrar que elas constituem todo ato de produção do enunciado em qualquer língua.

Quando o $e u$ do enunciado assume sua posição, ele instaura um agora que é o fundamento das oposições temporais da língua e é expresso pelo verbo. Esse agora é um eixo que coordena a categoria da concomitância e da não concomitância. A não concomitância divide-se, por sua vez, em anterioridade e posterioridade e, a partir dessa relação, criam-se três momentos de referência: um presente (que é o agora e coincide com o momento da enunciação), um passado (que indica uma anterioridade em relação ao momento da enunciação) e um futuro (que marca a posteridade em relação ao momento da enunciação).

Há três momentos que determinam o tempo linguístico: o momento da enunciação (o momento em que o enunciado é produzido), o momento do acontecimento do evento (concomitante, anterior ou posterior aos momentos de referência) e o momento de referência (presente, passado ou futuro). 
Vamos observar o exemplo proposto por Banfi e Bernini em seu estudo intitulado "Il verbo" (2003: 74):

Ieri alle cinque Ababa era partita da Massawa.

[Ontem às cinco horas Abba havia partido para Massawa]

Como vemos, no exemplo, o momento da enunciação é posterior ao momento do acontecimento do evento, o qual, por sua vez, antecede o momento de referência "ontem às cinco horas".

O tempo verbal diretamente relacionado ao momento da enunciação é o presente. A partir do tempo presente que implica concomitância, instaura-se a categoria não concomitância, que gera um momento anterior, o pretérito e, um posterior, o futuro. No ensaio intitulado "Pragmática", o linguista José Luiz Fiorin (2003) afirma que a anterioridade em relação ao momento de referência presente é concretizada através do pretérito perfeito (passato prossimo do italiano). No português, os dois pretéritos apesar de apresentarem anterioridade em relação ao momento de referência presente, exprimem ações de diferentes valores de aspecto. O pretérito perfeito simples expressa uma ação acabada, pontual, dinâmica e limitada e, o pretérito perfeito composto, por sua vez, indica uma ação começada anteriormente ao momento de referência presente e, ao mesmo tempo, indica sua continuidade no momento presente. Podemos visualizar essa diferença através dos exemplos: João leu até tarde (pretérito perfeito simples) e João

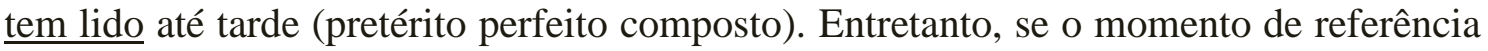
é o pretérito, criam-se ainda dois subsistemas baseados na relação de concomitância e não concomitância. Na categoria concomitância há a diferença entre o tempo verbal que marca uma ação acabada, pontual, limitada e dinâmica e outro tempo verbal 
caracterizado por marcar o aspecto inacabado, durativo, não limitado e estático do verbo, isto é, os tempos verbais são diferenciados pelos aspectos perfectivo e imperfectivo. Em italiano os dois tempos que expressam ações passadas concomitantes a um momento de referência pretérito são o passato remoto e o imperfetto do indicativo.

\section{SISTEMA ENUNCIATIVO}

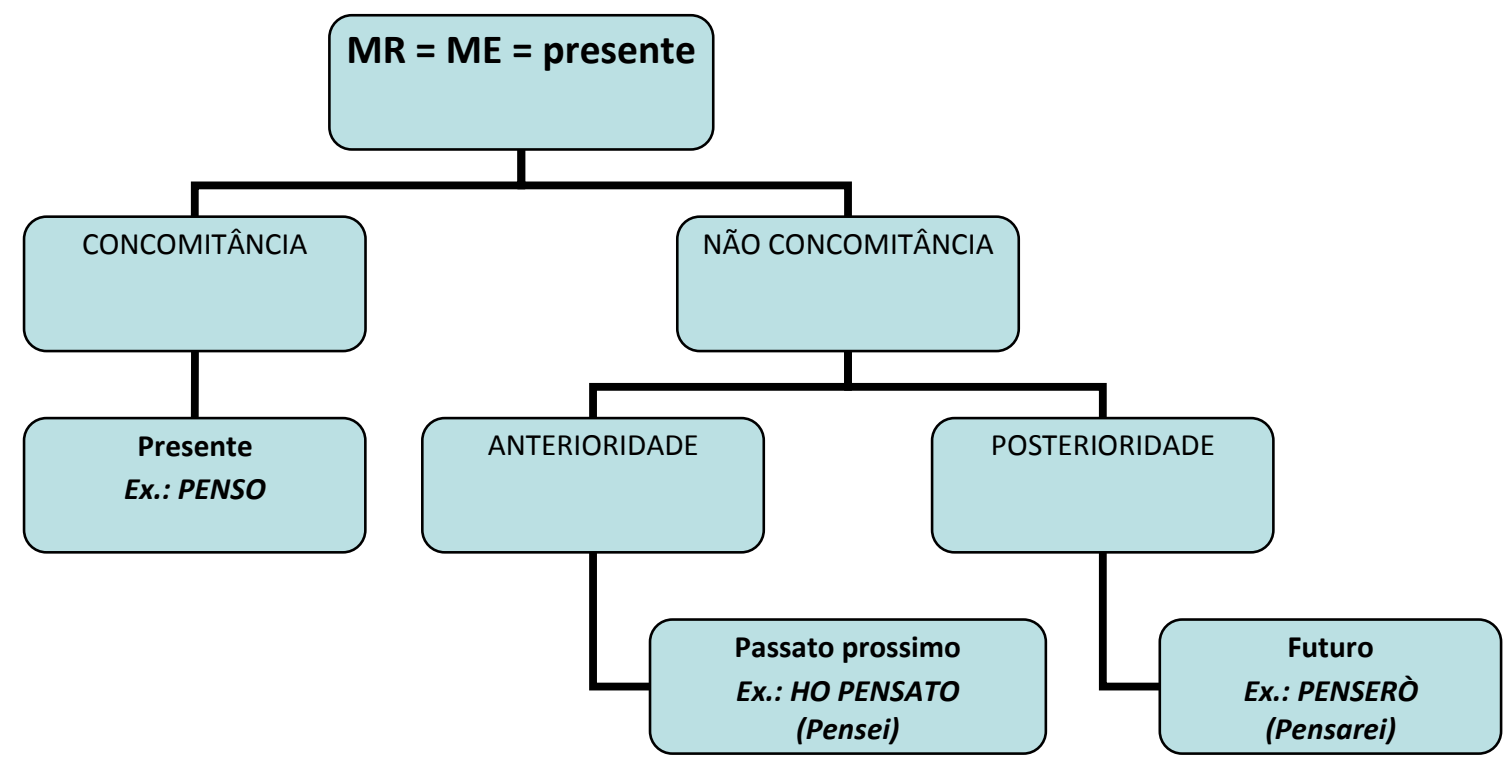

SISTEMA ENUNCIVO (passado)

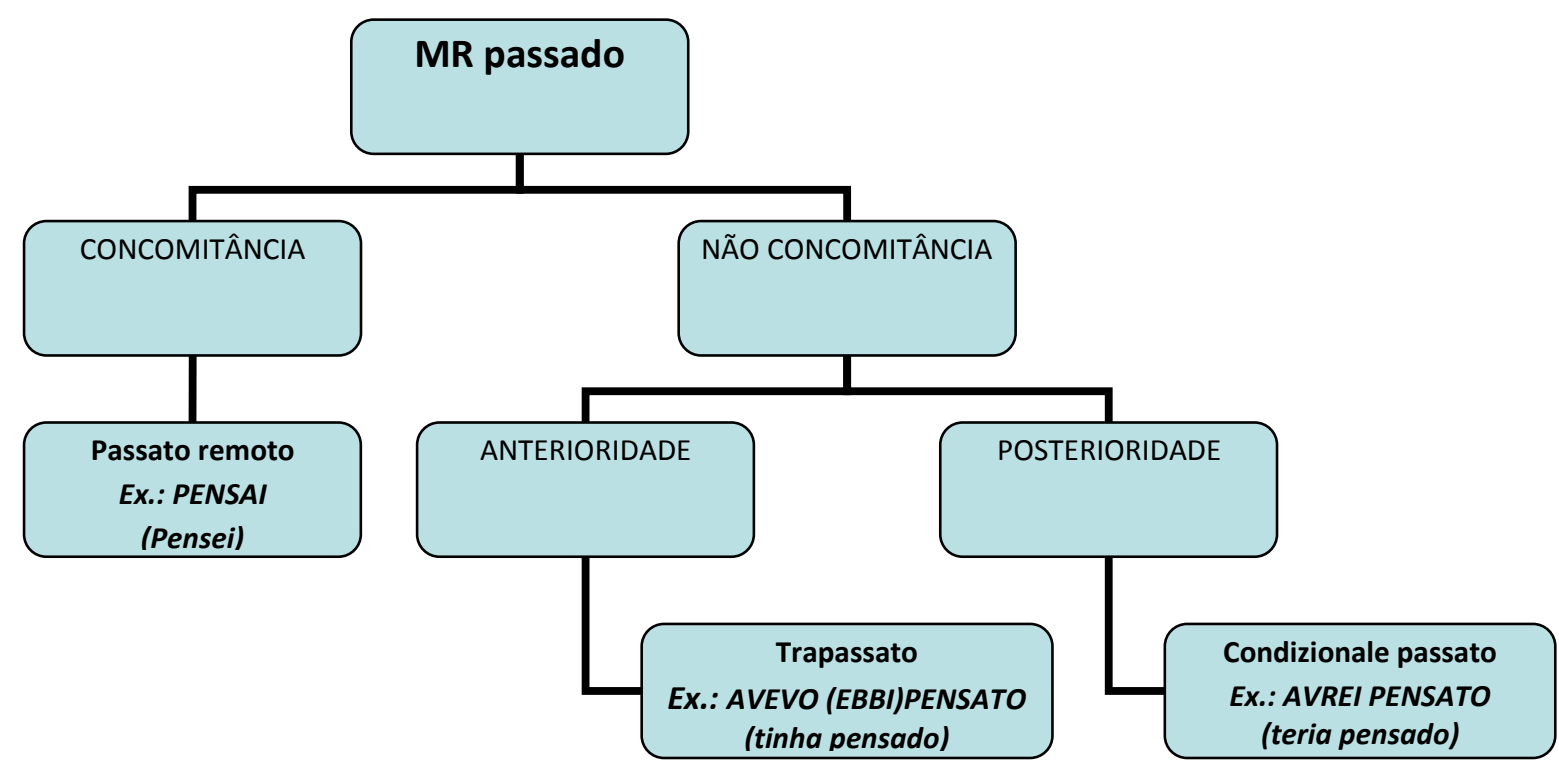


Nos esquemas acima foram colocados apenas os tempos perfectivos, tanto na anterioridade em relação ao momento da enunciação do sistema enunciativo, quanto na concomitância em relação ao momento de referência pretérito do sistema enuncivo. No sistema verbal do italiano consideramos tanto o passato prossimo quanto o imperfetto como tempos que indicam anterioridade em relação ao momento presente da enunciação, diferindo em relação ao aspecto. Sendo assim, partimos do pressuposto de que a alternância entre os tempos ditos do passado não ocorre apenas no subsistema pretérito (em italiano, entre passato remoto e imperfetto), mas também no subsistema que indica anterioridade em relação ao momento da enunciação, ou seja, entre passato prossimo e imperfetto que indicam não concomitância em relação ao momento presente da enunciação, já que indicam anterioridade, mas podem ser concomitantes entre si, marcando apenas diferenças aspectuais. O aspecto verbal apresenta o ponto de vista do falante em relação àquilo que diz, sua natureza é morfológica e constitui-se a partir das diversas combinações entre tempos verbais. Na Grande grammatica di consultazione della lingua italiana Bertinetto afirma que:

Se considerarmos um determinado processo por um ponto de vista imanente, ou seja, tendo em vista a sua constituição íntima e as suas modalidades de desenvolvimento específicas, mais que sua localização no tempo e a rede de relações temporais em que é inserido, então são trazidas para o primeiro plano não as propriedades especificamente temporais do verbo, mas sim as suas propriedades 'aspectuais'. Por exemplo, pode se considerar uma dada situação na sua globalidade, como um processo único não ulteriormente analisável; ou ainda se pode aproveitá-la em uma certa fase do seu desenvolvimento; ou se pode considerá-la no perdurar do seu resultado, além do seu desenvolvimento; ou ainda, pode-se insistir na sua habitualidade com a qual a própria situação tende a se apresentar; e assim por diante. ${ }^{4}$ (BERTINETTO 1991: 21).

\footnotetext{
4 "Se invece consideriamo un determinato processo da un punto di vista immanente, ossia avendo di mira la sua intima costituzione e le sue specifiche modalità di svolgimento, piuttosto che la sua localizzazione nel tempo e la rete di rapporti temporali in cui è inserito, allora vengono portate in primo piano non le proprietà specificamente temporali del verbo, bensì le sue proprietà 〈aspettuali>. Ad es., si può considerare una data situazione nella sua globalità, come un singolo processo non ulteriormente analizzabile; oppure la si può cogliere in una certa fase del suo svolgimento; ovvero, si può considerarla nel perdurare del suo risultato, anziché nel suo svolgersi; o ancora, si può insistere sull'abitualità con cui la situazione stessa tende a presentarsi; e cosi via".
} 
Vejamos os exemplos:

a) Ieri ho fatto un compito terribile. [Ontem fiz uma lição terrível].

b) Ieri mentre facevo un compito terribile, il mio cellulare è suonato tre volte.

[Ontem enquanto fazia uma lição terrível, meu celular tocou três vezes].

Os exemplos $a$ e $b$ marcam ações anteriores ao momento da enunciação. Entretanto, no exemplo $a$, o verbo ho fatto (passato prossimo) marca uma ação acabada, pontual, dinâmica e limitada, anterior ao hoje e ao agora, cuja anterioridade enunciativa é demonstrada também pelo advérbio de tempo ieri (ontem). Passemos agora ao exemplo $b$ que apresenta dois verbos que em oposição aspectual, ambos anteriores ao momento da enunciação, já que essas ações também são reforçadas pela presença do advérbio ieri. O verbo facevo (em italiano: imperfetto) marca em uma linha temporal uma ação que se desenvolvia no passado, ou seja, uma ação durativa, estática, não limitada e inacabada, enquanto o verbo è suonato (em italiano, passato prossimo) indica uma ação que interrompe aquela que se desenvolvia, sendo a ação, por sua vez, pontual, dinâmica, não-limitada e acabada.

Em relação à codificação do tempo, dividimos o sistema da língua italiana em presente, passado e futuro.

O tempo presente constitui a categoria central. Indica coincidência e simultaneidade de um evento em relação ao seu momento da enunciação, estende-se em um espaço temporal mais ou menos amplo tanto no passado quanto no futuro, e ainda indica verdades universais, sendo assim chamado de presente gnômico ou omnitemporal.

O passado refere-se a eventos precedentes ao momento da enunciação: no indicativo, tendo como base o aspecto, distinguem-se o passado imperfectivo e o 
passado perfectivo, aquele caracterizado pelo imperfetto e estes representados pelos passato prossimo e passato remoto.

Segundo a gramática italiana de Moretti e Orvietto (1984), o passato prossimo exprime fatos acontecidos no tempo passado, que manifestam referência em relação ao presente: ou pela brevidade real ou imaginada do tempo transcorrido, ou pelos efeitos e resultados que perduram no presente. O exemplo utilizado na citada gramática é:

Oggi, di colpo, ho capito cosa lei mi ha già dato: questa consapolezza, questa capacità di vedermi come sono realmente, come sono sempre stato. (G. Arpino: La Suora Giovane, 17).

[Hoje, de repente, percebi o que ela já me deu: esta consciência, esta capacidade de me ver como sou realmente, como sempre fui.]

Os verbos no passado (ho capito, ha dato, sono stato) apresentam relação com o presente, que também é percebida pelos advérbios de tempo presentes no texto, a saber: oggi, indicando o tempo transcorrido desde o início do acontecimento até o momento da enunciação; già evidenciando um resultado que, tendo se iniciado no passado, perdura até o momento presente; sempre, mostrando continuidade no presente de uma condição iniciada no passado.

Dessa maneira, ainda segundo a mesma gramática, o passato prossimo exprime:

a) fato concluído em relação ao momento em que é enunciado e ao momento a que se refere;

b) fato observado com interesse no seu término e realização. Tal interesse é motivado pelo senso de participação que repercutem na memória do enunciador no momento da enunciação e pode ser acompanhado por advérbios;

c) fato inscrito em um período de tempo não definido, mas sentido como recente;

d) fatos ocorridos em um período de tempo remoto, mas ligado ao presente por efeitos de natureza variada (física, prática, moral, psicológica, cultural). 
O passato remoto, por sua vez, ainda segundo Moretti e Orvietto (1984), aponta ações em sucessão e inscritas no tempo "sentido" como fechado e distante. Eles afirmam que quando há uma precisa indicação temporal para certas realizações do passado não recente e que não apresentam ligação com o presente, é mais apropriado o uso do passato remoto, pois este situa os fatos pontualmente em um tempo passado sem ligação com o momento presente.

Podemos estabelecer diferenças entre o passato prossimo e o passato remoto, utilizando os exemplos escolhidos por Serianni (2001: 327) e retomados por Santoro (2009: 136):

a) Dio ha creato il mondo. [Deus criou o mundo.]

b) Due anni fa andammo in Scozia. [Há dois anos fomos à Escócia.]

O primeiro enunciado remete ao tempo mítico e remoto da criação do mundo e foi formulado com o passato prossimo, mas, por outro lado, o segundo exprime uma ação ocorrida há apenas dois anos e que, no entanto, é expressa por meio do passato remoto. Considerando que os dois enunciados são aceitáveis e corretos, percebemos que a diferença não se baseia na distância temporal estabelecida pelo tempo crônico. Apenas para verificar sua aceitabilidade, observamos que as duas sentenças poderiam ser reproduzidas da seguinte maneira:

a) Dio creò il mondo.

b) Due anni fa siamo andati in Scozia.

Em português, ambas seriam traduzidas como nos exemplos anteriores, entretanto, apresentam uma diferença no que diz respeito à sua ligação com o momento 
de referência. O passato remoto pertence ao subsistema do passado (sistema enuncivo) e indica uma concomitância em relação ao momento de referência do passado. É essa a razão pela qual cria o efeito de distanciamento, citado por Moretti e Orvietto, entre o enunciador e o enunciado, ou seja, não apresenta ligação com o momento da enunciação e, portanto, não é reatualizado (cf. Bertinetto 1991). Esse é o motivo pelo qual o passato remoto é considerado o tempo da história e é visto com muita frequência em livros de história e nas fábulas. Enquanto, o passato prossimo por caracterizar uma ação anterior ao momento de referência presente (sistema enunciativo) cria o efeito de aproximação entre o enunciador e o enunciado produzido e é, por isso, cada vez mais utilizado, por exemplo, na língua falada, pois na fala, mais do que na escrita, a ligação com o momento de referência presente que corresponde também ao momento da enunciação é forte e frequente.

Apesar da existência dessas diferenças, é necessário considerar que tanto o passato prossimo quanto o passato remoto, que pertencem a sistemas diferentes, apontam, como vimos, características perfectivas, isto é, expressam características de ações acabadas, pontuais, limitadas e dinâmicas.

Na gramática observada, o passato remoto é definido como o tempo que marca fatos que não sejam habituais, nem durativos, mas iniciados, concluídos e limitados em um tempo determinado. Estes fatos estão longe do passado (na realidade ou na psique de quem fala ou escreve) e não possuem ligação com o momento de referência presente. Seguindo essa definição, o passato remoto é usado para:

a) narrar fatos momentâneos especialmente no momento de iniciar e concluir a descrição de ações; 
b) expressar fatos únicos ou repetidos, mas não habituais e com início e conclusão em um espaço de tempo determinado e marcado no contexto por locuções perfectivas do tipo "um ano" ou "um século";

c) expressar fatos que quase aconteceram, acompanhados por expressões ou substituir o presente nos provérbios.

Cabe acrescentar que a nomenclatura dos tempos do passado que indicam perfectividade não é a mais adequada porque tanto o passato prossimo quanto o passato remoto possuem no nome adjetivos que podem propiciar uma falsa ideia sobre seu uso. De fato, o passato prossimo, contradizendo seu nome, não se refere apenas a ações que aconteceram recentemente, assim como o passato remoto não é usado apenas para expressar ações mais distantes do ponto de vista temporal. Por esta razão, Pier Marco Bertinetto (1991) adota os nomes perfetto semplice (perfeito simples) e perfetto composto (perfeito composto) referindo-se, respectivamente, a passato remoto e passato prossimo, já que o primeiro é um tempo simples e o segundo é um tempo composto, ou seja, formado pelo verbo auxiliar e pelo particípio do verbo principal. Entretanto, neste trabalho adotamos a nomenclatura passato prossimo e passato remoto por ser o uso mais conhecido e tradicional.

Outro tempo dito do passado é o imperfetto que apesar de ser concomitante com esses dois tempos perfectivos, assume diferenças de aspecto, como já dissemos anteriormente.

O imperfetto na gramática de Moretti e Orvietto (1984) é definido como um tempo que exprime fatos em curso de desenvolvimento no passado, sendo por isso, um dos tempos típicos da descrição. Apesar dessa definição, cabe acrescentar que não é o 
único tempo usado para descrever eventos. O imperfetto marca o aspecto imperfectivo, ou seja, ações inacabadas, durativas, ilimitadas e estáticas. O imperfetto se usa:

a) na descrição, no passado, de pessoas, animais, objetos, lugares, modos de vida, instituições entre outros onde o início e a conclusão não são o que interessa no acontecimento, que se evidencia pela sua continuidade;

b) na expressão de fatos habituais;

c) na descrição de circunstâncias e situações iniciadas e que perduram no momento da enunciação em que se verificam fatos expressos com um passado;

d) para enunciar fatos que ficaram na intenção, no desejo e não se realizaram.

Cabe considerar que o imperfetto também pode assumir valor modal substituindo outro tempo verbal, como se verifica na substituição do condizionale passato (condicional passado), por exemplo, em dovevo (devia) por avrei dovuto (deveria) ou potevo (podia), por avrei potuto (poderia), ou quando substitui o presente do indicativo ou o condicional para expressar uma intenção.

Faremos agora uma descrição das ações mostradas pelos próprios verbos. No já citado estudo intitulado "Il verbo" Banfi e Bernini (2003) afirmam que todo verbo é caracterizado pela ação que corresponde ao tipo de ação descrita. A partir desta ação, os verbos se classificam essencialmente em: a) durativos, isto é, aqueles cujas ações perduram no tempo; b) pontuais, ou seja, aqueles que apresentam as ações no seu desenvolvimento, mostrando um momento inicial e outro final. Podemos relacionar essa primeira distinção ao aspecto verbal, isto é, os verbos durativos são aqueles que expressam aspecto imperfectivo, enquanto os verbos pontuais são relacionados ao aspecto perfectivo. Como vimos, o aspecto verbal é de natureza morfológica. 
Outra definição pertinente no momento é a que concerne à ação verbal. O conceito de ação é ligado ao significado do predicado verbal. A principal característica da ação é aquela que opõe os verbos durativos aos não durativos. Os verbos do primeiro tipo referem-se a processos que apresentam uma duração (por exemplo, crescere crescer, dormire - dormir), enquanto os verbos do segundo tipo relacionam-se a processos com desenvolvimento rápido, que pode até dar a ilusão de coincidir perfeitamente com momento da enunciação - (por exemplo, esplodere - explodir, arrivare - chegar, cadere - cair). Cabe considerar que o contexto influencia essa determinação porque, na verdade, todos os verbos apresentam uma duração, ainda que mínima, entretanto há verbos que apresentam traços de maior duratividade e outros que tem duratividade menor. Mas há, por exemplo, verbos que não aceitariam advérbios de duração por serem relacionados a verbos não durativos. Utilizaremos alguns dos exemplos propostos por Bertinetto (1991):

* La nave esplose finché durò l'attacco.

[A nave explodiu enquanto durou o ataque.]

O verbo explodir, não durativo, não aceita o uso do advérbio finché, pois este transmite a ideia de duração, o que não condiz com a ação do verbo e é por isso que, como mostra o asterisco, esta frase é considerada agramatical.

Segundo a proposta de Bertinetto, uma subclasse dos verbos não durativos é constituída por verbos que indicam uma mudança repentina de estado, são os chamados verbos transformativos como, por exemplo, trovare (encontrar), ritornare (retornar), fermarsi (parar), etc. chamados assim porque sempre indicam uma transformação, uma mudança entre o antes e o depois da ação mencionada. Há também verbos não durativos e que não indicam transformação, são os chamados pontuais, como stupirsi (pasmar-se) 
ou spaventarsi (assustar-se), ditos assim porque o momento do acontecimento e o momento da referência são coincidentes.

A segunda distinção no sistema verbal proposta por Banfi e Bernini (2003: 71) refere-se aos verbos télicos e atélicos. Os primeiros são os verbos que visam ao cumprimento/realização de algo, enquanto os verbos atélicos não representam essa característica.

Os exemplos usados pelos próprios autores são os verbos dipingere un quadro (pintar um quadro) e chegar (arrivare), ditos télicos, e pintar, caracterizado como atélico. É preciso acrescentar que do grupo dos verbos télicos fazem parte também os verbos durativos, ou seja, aqueles que apresentam duração, dinamismo e telicidade (pintar um quadro, tomar banho, subir a escada) chamados de resultativos, porque implicam a realização de um resultado, ou aqueles (explodir, reconhecer) conhecidos como transformativos que, por sua vez, apresentam dinamismo e telicidade, porém não apresentam duração. No grupo dos verbos atélicos encaixam-se os verbos pontuais, ditos também verbos de atividade, segundo a nomenclatura de Vendler (1967). Esses verbos possuem duração e dinamicidade, entretanto não apresentam telicidade (como no caso de caminhar, trabalhar, tomar sol). E há, ainda, no grupo dos verbos atélicos os chamados durativos ou, conforme Vendler, estativos, pois apresentam uma duração, mas não possuem dinamicidade e telicidade, ou seja, um ponto em que possa ser dito que a ação está concluída (saber, conhecer, amar). Em geral, todos os verbos que indicam qualidade permanente do sujeito ou estados que não podem ser modificados são considerados verbos de estado.

Os verbos pertencentes ao grupo dos não-resultativos e atélicos são aqueles que possuem traços de estado e que, em geral, não aceitam o imperativo, nem uma 
construção progressiva, mas dependem da interação do verbo e seus morfemas e seus complementos.

Dessa maneira, conforme Rastelli (2009) propõe seguindo a teoria de Vendler sobre telicidade e não telicidade, temos:

\section{Verbos atélicos}

a) Verbos de estado: + duração, - dinamicidade, - telicidade;

b) Verbos de atividade: + duração, + dinamicidade, - telicidade;

\section{Verbos télicos}

a) Verbos de "compimento" ou "accomplishment" (resultativos): + duração, + dinamicidade, + telicidade;

b) Verbos de "raggiungimento" ou "achievement" (transformativos): + dinamicidade, + telicidade, - duração.

Para visualizar melhor esse sistema, apresentamos a tabela proposta por Bertinetto (1986):

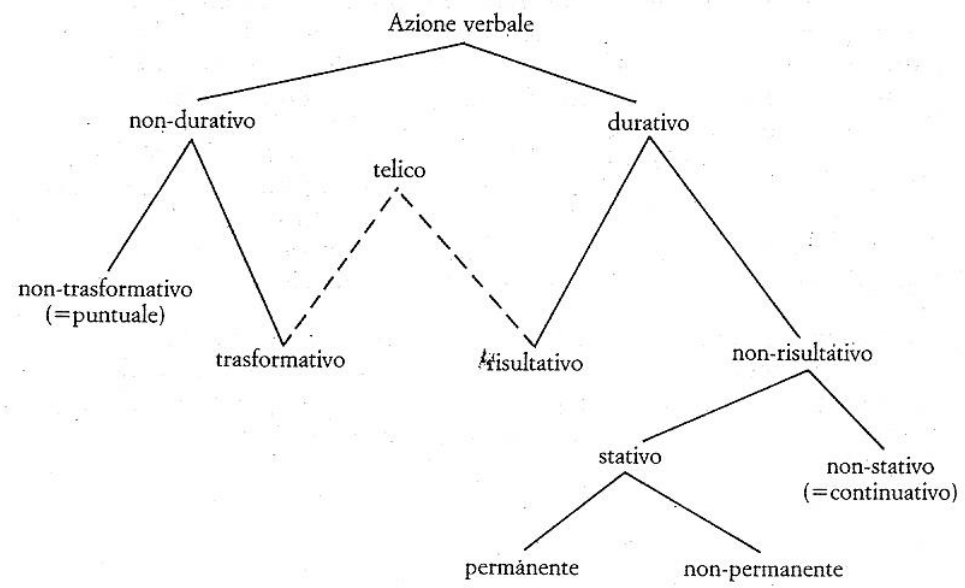

É interessante perceber que há muitos fatores que determinam modificações na ação verbal. Dessa maneira, quando se afirma que um verbo pertence à determinada 
classe, considera-se uma série de contextos típicos, mas não a totalidade de contextos em que esse verbo pode aparecer, sendo necessário avaliar todo o sintagma verbal. Para exemplificar esse fenômeno, levemos em consideração as orações propostas por Bertinetto (1986):

1 a. La pioggia cade. [A chuva cai] - ação durativa;

1 b. Il sasso cade. [A pedra cai] - ação não durativa;

2 a. Il vento colpisce il nostro volto. [O vento bate no nosso rosto]. Ação durativa;

2 b. Il proiettile colpisce il bersaglio. [O projétil atinge o alvo]. Ação não durativa.

Nos exemplos acima percebemos que a duratividade do verbo também é determinada pelo sujeito expresso na oração, comprovando que nas categorias de telicidade e não telicidade é necessário também considerar os argumentos verbais.

Depois de termos visto o tempo presente e os tempos do passado, cabe dizer que o futuro pode indicar um momento posterior ao momento de referência presente, nesse caso, é conhecido como futuro semplice (futuro simples), mas, por outro lado, também pode ser combinado com o participio passato, indicando assim um futuro em relação a uma ação passada, sendo conhecido então como futuro anteriore (futuro anterior).

1. Andrò al cinema. [Irei ao cinema]. - futuro semplice

2. Appena sarò tornata dal cinema mi metterò a studiare. [Assim que eu tiver voltado do cinema, estudarei]. - futuro anteriore

No que concerne ao modo, o sistema verbal é dividido em indicativo, isto é, o modo que se limita a constatar e expor fatos, ações e modo de ser reais e certos, criando os três tempos vistos anteriormente, a saber: passado, presente e futuro. Mas, há também os modos congiuntivo, condizionale e imperativo, que indicam respectivamente, frases dependentes, modalidades controfactuais e ordens. 


\subsection{A aquisição do sistema verbal da língua italiana}

Emanuele Banfi e Giuliano Bernini referindo-se à aquisição/aprendizagem do italiano como segunda língua ou como língua estrangeira, afirmam que "o percurso da aquisição prossegue no contínuo de variedades pós-básicas com a construção gradual do sistema verbal da língua de chegada nas suas dimensões nocionais e na codificação morfológica destas." 5 (2003: 84).

Considerando essa afirmação, podemos dizer que o aprendiz de italiano L2 adquire a forma base de um verbo (infinitivo) e que, a partir dela e segundo suas necessidades expressivas, esse aluno chega ao paradigma completo do sistema verbal, sendo que a sequência desta aquisição/aprendizagem, principalmente no que diz respeito à narração, se inicia com o uso do presente do indicativo, continua com a aquisição do passato prossimo, e prossegue com o imperfetto do indicativo. Considerando o conjunto do sistema verbal, cabe dizer que, em se tratando do tempo composto (verbo auxiliar + particípio passado) passato prossimo, o aprendiz espontâneo, utiliza, em um momento, apenas formas do particípio passado e só depois, com o passar do tempo, vai adicionando na sua produção o verbo auxiliar quando desejar fazer uso desse tempo. Posteriormente, passa-se ao imperfetto, depois, ao futuro do indicativo, ao condizionale e ao modo congiuntivo. O chamado Progetto di Pavia, formado por um grupo de pesquisadores do Departamento de Linguística da Universidade de Pavia, na Itália, a partir de 1980 estudou e descreveu o processo de aquisição/aprendizagem não formal, isto é, espontânea, do italiano como L2 por parte

\footnotetext{
5 "Il percorso di acquisizione prosegue nel continuum di varietà postbasiche con la graduale costruzione del sistema verbale della lingua di arrivo nelle sue dimensioni nozionali e nella codificazione morfologica di queste."
} 
de estrangeiros que viviam na Itália. A perspectiva adotada evidenciou a língua como ponto de contato com outras línguas e culturas e como instrumento de acesso à língua e cultura italianas. Esses estudiosos chegaram a essa sequência de aprendizagem após estudar e descrever o processo de aquisição/aprendizagem do italiano L2 por estrangeiros que aprendiam o italiano na Itália sem estudá-lo em contexto de instrução formal.

Em relação a essa distinção, Banfi e Bernini (2003) afirmam que os predicados télicos mostram a tendência de serem relacionados ao aspecto perfectivo, enquanto os atélicos, ao imperfectivo. Esse parâmetro, entretanto, não funciona como regra, apesar de seguir a teoria já elaborada por Andersen e Shirai (1996), denominada Aspect Hypothesis, onde os autores apontam que a seleção e o uso das marcas do passado perfectivo são restritos, inicialmente, para marcar predicados télicos (transformativos e resultativos), enquanto o passado imperfectivo é selecionado apenas para marcar predicados atélicos (verbos pontuais e de estado).

No processo de aquisição/aprendizagem da L2, o aprendiz se aproxima da língua alvo, quando é capaz de usar o aspecto verbal sem restringir-se às ações expressas pelos verbos, assim deve ser capaz de selecionar, por exemplo, a marca da perfectividade associando-a também a predicados que exprimem estado, pois em determinados contextos eles assumem interpretação dinâmica.

Esses pressupostos foram utilizados também no estudo "Le categorie tempoaspettuali dell'italiano in prospettiva acquisizionale”, no qual Fabiana Rosi (2008: 5385) analisou a interação no processo de aquisição/aprendizagem do italiano como L2 em contexto formal através de atividades durante as quais os aprendizes respondiam as entrevistas com perguntas pessoais, assistiam a trechos de filme e, em seguida, contavam a história do que haviam visto e, como última atividade, completavam um 
texto, cujos espaços vazios deveriam ser preenchidos com o tempo verbal (passato prossimo ou imperfetto) correto do verbo proposto. Essas tarefas, com exceção da última, eram guiadas por professores que faziam perguntas cujos objetivos principais eram relacionados ao uso do passato prossimo ou do imperfetto.

A pesquisa mostrou resultados que confirmaram a citada teoria da Aspect Hypothesis. Entretanto, a autora acrescentou que, se nos primeiros níveis da língua o aprendiz relaciona o tipo de predicado ao uso do aspecto perfectivo ou imperfectivo, nos níveis avançados, a seleção do aspecto é influenciada pela função discursiva e não mais pelo valor acional do predicado. Segundo a estudiosa nos níveis avançados diminui a influência do valor da ação e aumenta a incidência da função discursiva do contexto. Esse resultado, segundo ela, é alcançado em consequência da evolução dos aprendizes na aprendizagem da morfologia aspectual devido à sua exposição ao input em língua italiana.

A seleção da marca morfológica correta é adquirida aos poucos pelos aprendizes da L2, pois estes passam por um processo de construção da sua própria competência linguística do idioma estrangeiro. 


\section{Teorias de aquisição da $L 2$}

A partir da segunda metade do século XX, iniciaram-se estudos sistemáticos sobre os processos de aquisição da competência linguística e, mais especificamente, sobre os processos e modelos relativos à aquisição da L2.

Acompanhando o aumento do interesse pela aprendizagem de línguas estrangeiras, difundiram-se além dos estudos sobre a aquisição da L2, muitas pesquisas que buscaram compreender e elaborar métodos de ensino mais eficazes, resultando no crescimento da produção de materiais didáticos.

Os estudos sobre a aquisição de L2 têm por objetivo descrever e explicar os processos de aprendizagem da L2 a fim de compreender o seu funcionamento. A disciplina Aquisição de Segundas Línguas (Second Language Acquisition) procura entender o processo de aquisição de uma L2 se baseando sempre em dados colhidos e na análise da língua que os falantes produzem, tanto oralmente quanto por escrito, quando solicitados.

Há duas possibilidades de coleta de dados que definem dois tipos distintos de pesquisa, sendo a primeira delas transversal, quando são fornecidas pelo falante amostras da L2 em um só momento do processo de aprendizagem e, ainda, a pesquisa longitudinal, em que a coleta é realizada em diferentes estágios da aquisição, possibilitando, assim, descobrir como se desenvolve gradualmente esse conhecimento sobre a L2. No presente trabalho, foi escolhida a pesquisa de tipo longitudinal e, para tanto, os aprendizes da língua italiana foram testados em quatro estágios do período de 
aprendizagem e, por isso, foram obtidas várias amostras referentes ao percurso por eles realizado. ${ }^{6}$

\subsection{Os fatores internos e externos na aquisição}

Os estudos desenvolvidos nessa área de pesquisa permitiram identificar alguns fenômenos, que ajudam a explicar como se dá a aquisição de uma L2, entre eles, podemos mencionar os fatores internos e externos que influenciam o processo da aquisição. Sobre a distinção dos fatores mencionados, Pallotti afirma o seguinte:

Há dois macro-fatores indispensáveis para que se possa falar de aquisição da segunda língua. Por um lado, é necessário um ser humano, isto é, uma criatura com determinadas características. Por outro, é necessário um determinado ambiente [...]. Por um lado, de fato, será necessário estudar com maior detalhe a constituição humana; por outro será necessário estudar o que precisamente "acontece em torno" dos indivíduos que permite que eles passem do estado de não conhecimento da L2 para o estado de competência mais ou menos desenvolvida. ${ }^{7}$ (PALLOTTI, 1998: 150-151).

Portanto, podemos considerar que os fatores que influenciam o processo de aquisição da L2 que estão ligados à constituição dos mecanismos cognitivos do indivíduo, permitindo-lhe extrair informações da língua-alvo, são chamados de internos e se relacionam:

- à própria constituição humana no que diz respeito à capacidade de organização e elaboração das informações presentes no input, isto é, a todo e qualquer

\footnotetext{
${ }^{6}$ Sobre metodologia de pesquisa em aquisição de segundas línguas, ver, entre outros: NUNAN (1992), TARONE/GASS/COHEN (1994) e MACKEY/GASS (2005).

7 "Due sono i macro-fattori indispensabili perché si possa parlare di acquisizione della seconda lingua. Da un lato, è necessario un essere umano, cioè una creatura con determinate caratteristiche. Dall'altro, è necessario un determinato ambiente [..]. Da un lato, infatti, ocorrerà studiare in maggiore dettaglio la costituzione umana; dall'altro bisognerà studiare cosa precisamente 'accade intorno' agli individui che fa sì che essi passino da uno stato di non conoscenza della L2 a uno stato di competenza più o meno sviluppata”. (PALLOTTI, 1998: 150-151).
} 
"material linguístico ao qual o aprendiz é exposto"8 (PALLOTTI, 1998: 14) em língua estrangeira;

- ao conhecimento de mundo que o indivíduo já possui e a sua capacidade de estabelecer ligações com as novas informações;

- às estratégias comunicativas que o ajudam a construir o conhecimento da L2, ou seja, a disposição natural que apresenta para adquiri-la e compreendê-la.

Essas estratégias são divididas em metacognitivas, que se referem às atitudes do aprendiz para prestar atenção nas tarefas que precisam ser desenvolvidas, assim como examinar o objeto de estudo, organizar-se e auto-avaliar; em cognitivas, que dizem respeito às elaborações dos conhecimentos precedentes e, ainda, à capacidade de inferir, deduzir e transferir informações, conceitos e traduções; e, por fim, em estratégias sociais e afetivas que consistem em pedir esclarecimentos, trabalhar em grupo no desenvolvimento de tarefas e no controle da própria ansiedade em aprender a nova língua (PALLOTTI, 1998: 257-259).

Como observamos anteriormente, além dos fatores internos, existem condições presentes no ambiente de aprendizagem que interferem no processo de aquisição da L2 e são conhecidos como fatores externos.

O input pertence a esses elementos e a sua compreensão por parte do falante, pode não ser suficiente para que a aquisição se realize, porém desempenha uma função importante visto que fornece para o aprendiz amostras da língua-alvo, as quais podem ocorrer em menor ou maior quantidade. Embora, a tendência seja concluir que a maior exposição ao input é capaz de gerar maior aquisição, cabe considerar a afirmação de Pallotti:

8 "Il materiale linguistico al quale viene esposto l'apprendente". 
[...] a excessiva e exclusiva exposição à L2 pode levar mesmo a uma desaceleração do desenvolvimento linguístico geral; no caso dos adultos, que já completaram tal desenvolvimento, pode acontecer que muito input além de um certo patamar seja inútil, se não danoso já que é estressante. De fato não é necessário esquecer que a transformação do input em intake depende da última análise do aprendiz: somente isso pode fazer com que o material linguístico em torno seja notado, elaborado, analisado e integrado ao sistema interlinguístico, e a pura e simples quantidade de input não é capaz de produzir esses efeitos. ${ }^{9}$ (PALLOTTI, 1998: 157-158).

É mais relevante o input compreensível do que a sua grande quantidade, porque a compreensão ativará mecanismos dentro do cérebro do aprendiz que o levará à elaboração de dados e hipóteses sobre a língua até que essas estruturas sejam integradas ao sistema. Pallotti utiliza a palavra intake referindo-se à parte do input em que o aprendiz prestou atenção e que permanece na memória.

Sobre a aquisição, Krashen já havia formulado cinco hipóteses, que serão abordadas posteriormente em nosso trabalho, entre as quais, aquela que se refere ao input "os seres humanos adquirem a língua somente de uma maneira - pela compreensão das mensagens ou recebendo 'input compreensível' "10 (KRASHEN, 1985: 2). Para definir a compreensibilidade do input, o autor afirma que ela corresponde ao $i+1$, em que o " $i$ ” representa as estruturas já conhecidas pelo aprendiz e o 1 , por sua vez, um nível superior ao conhecimento do aluno, modelo que, segundo Krashen, provocará no aprendiz a aquisição das novas estruturas da língua.

Outro fator externo que influencia a aquisição relaciona-se à interação entre os falantes, sejam eles nativos ou não, pois a troca de turno por eles realizada para que exista a comunicação, estimula o aprendiz a entender o conteúdo da mensagem e lhe

\footnotetext{
9 “[...] l'eccessiva ed esclusiva esposizione alla L2 può portare addirittura a un rallentamento dello sviluppo linguístico generale; nel caso degli adulti, che hanno già completato tale sviluppo, può darsi che troppo inpu oltre una certa soglia sia inutile, se non addirittura dannoso perché stressante. Non bisogna infatti dimenticare che la trasformazione dell'input in intake dipende in ultima analisi dall'apprendente: è solo questi che può fare sì che il materiale linguistico venga notato, elaborato, analizzato e integrato al sistema interlinguistico, e la pura e semplice quantità di inpu non in grado di produrre tutti questi effetti."

10 "Humans acquire language in only one way - by understanding messages or by receiving 'comprehensible input'."
} 
permite desenvolver as suas estruturas linguísticas nas tentativas de expressar-se e fazer-se compreender. $\mathrm{Na}$ interação, o aprendiz encontra oportunidades para testar as suas hipóteses em relação à língua buscando a compreensão do seu interlocutor através das suas próprias produções orais, também importantes na aquisição da L2.

Nos fatores externos podem ser incluídos os tipos de relação existentes e formados entre o aprendiz e o grupo no qual está inserido, se é um grupo acolhedor ou não, se o processo de aprendizagem ocorre em outro país ou naquele de origem, se as características desse grupo são de fortes ligações culturais e sociais e qual é o tipo de integração estabelecida entre o grupo e o aprendiz. Esses elementos podem favorecer ou provocar a desaceleração e o bloqueio no aprendizado da L2.

\subsection{Das disciplinas Aquisição de Segundas Línguas e Didática da L2}

Se, por um lado, os estudos sobre as segundas línguas se expandiram nos últimos anos, por outro, a maneira como são ensinadas, também tem sido foco de outra disciplina, a chamada Didática das línguas estrangeiras ou da L2, ${ }^{11}$ cujo objetivo é o estudo da prática do ensino de uma L2 para serem definidas abordagens e técnicas que garantam a aprendizagem eficaz, enquanto, ao contrário, o foco da disciplina Aquisição de segundas línguas consiste em explicar o processo de aprendizagem, conforme dissemos anteriormente.

\footnotetext{
${ }^{11}$ Neste trabalho, decidimos não considerar as diferenças entre língua estrangeira e segunda língua e, por isso, utilizamos sempre L2. Porém, nesse momento aparece língua estrangeira porque é o nome da disciplina que, em italiano, se afirmou com o nome de Glottodidattica.
} 
Assim a disciplina Aquisição das segundas línguas é empírico-descritiva e possui ambições teórico-explicativas, visto que busca explicar a língua a partir da sua observação (CHINI, 2005: 10). Em contrapartida, a Didática das línguas estrangeiras ou L2 examina a prática e as atividades em sala de aula e busca guiar o comportamento dos professores configurando-se, então, como uma disciplina teórico-prática.

As duas disciplinas estão interligadas: somente a partir da compreensão e reflexão sobre o processo de aquisição, podem ser entendidas as maneiras como o aprendiz desenvolve as suas hipóteses e podem ser identificadas soluções, que poderão ser aplicadas ao ensino da L2. Conforme dissemos, os objetivos são diferentes, porém, os resultados obtidos através dos estudos realizados pela Aquisição das segundas línguas gerarão dados importantes a serem considerados pela Didática, determinando a sua prática e a didática, por sua vez, empregada no ensino pode influenciar a aquisição e a aprendizagem da L2.

A língua é um fenômeno muito complexo e o seu aprendizado permite o funcionamento de vários mecanismos cognitivos e envolve muitos fatores internos e externos, como já mencionamos. Assim, a separação das disciplinas de Aquisição das segundas línguas e Didática das línguas estrangeiras ou L2 possibilitou um novo olhar e novas reflexões sobre os processos de aquisição, concluindo-se também, através de diversos estudos, que não existe um único modelo teórico que explique a aquisição da L2, ao contrário, existem correntes de estudo que, durante anos, e até hoje, buscam definir, entender e refletir sobre a língua alvo. 


\subsection{Krashen e o modelo do monitor}

Dentre os importantes estudos realizados, discutiremos as teorias dos autores que mais marcaram a história dos estudos da aquisição, citando, primeiramente, o modelo monitor de Stephen Krashen que se apoia em cinco hipóteses capazes de explicar, segundo ele, o processo de aprendizagem da L2.

A primeira hipótese consiste na distinção entre aquisição e aprendizagem (Acquisition/Learning Hypothesis), as quais representam processos e resultados distintos. A aquisição é um processo automático desenvolvido no subconsciente, processo que está focado no ato comunicativo e se assemelha àquele que ocorre na criança durante a aquisição da língua materna. A aprendizagem, por outro lado, é um processo consciente em que o aprendiz se esforça para aprender formalmente as "regras" da língua. De acordo com Krashen, a fluência na performance da L2 está relacionada às estruturas que o aprendiz adquiriu e não ao que ele aprendeu. Segundo essa proposta, os aprendizes adultos deveriam tentar ao máximo adquirir a língua estrangeira para poder alcançar a fluência comunicativa, pois, de outra forma, eles seriam bloqueados no aprendizado pelas "regras", pela atenção consciente às formas da língua e, até mesmo, pela percepção do próprio progresso. Nessa perspectiva, não havendo interface entre a aquisição e a aprendizagem, já que um processo elimina o outro, a aprendizagem não pode ser transformada em aquisição e, por isso, em sala de aula, deveriam ser adotadas estratégias e atividades que possibilitassem em maior grau a aquisição e um número menor de atividades que visassem à aprendizagem.

A primeira hipótese permite alguns questionamentos, entre eles, por exemplo, os seguintes: o uso de uma estrutura linguística aprendida, em um determinado momento, 
não pode ser transformado em aquisição? Seguindo o raciocínio proposto pelo autor, as crianças adquirem as estruturas de sua língua materna, isto é, não as elaboram de forma consciente. Acontece, no entanto, que em alguns momentos, na escola ou por influência dos pais e de outros adultos, as crianças são expostas às "regras" da língua sobre as quais são levadas a refletir de maneira consciente. $O$ uso consciente não poderá permitir, após um tempo, o uso inconsciente, através da internalização dessas regras? Esse processo não poderia ser parecido para um aprendiz de uma L2?

Seguindo a teoria de Krashen, o conhecimento do processo de aprendizagem tem a função de atuar na produção do enunciado como um Monitor, isto é, modificando-o se não estiver de acordo com as regras aprendidas. O Monitor (Monitor Hypothesis), segunda hipótese formulada, entra em funcionamento em três situações específicas: quando o foco do falante está na forma, se ele conhece as regras da língua e, ainda, de acordo com o tempo que tem sido exposto à L2. Se essas condições são atendidas, o aprendiz é levado a realizar alterações ou correções na sua produção de maneira consciente, pois o seu Monitor é ativado.

A terceira hipótese recebe o nome de Ordem Natural (Natural Order). O autor sugere que existe uma ordem previsível na aquisição das estruturas gramaticais da L2, ou seja, algumas estruturas linguísticas tendem a ser adquiridas antes do que outras, que serão internalizadas mais tarde. Essa sequência não corresponde à mesma da língua materna e diz respeito apenas às regras adquiridas inconscientemente, portanto, no que concerne ao aprendizado guiado, esse modelo não se encaixa, visto que a sequência de estruturas aprendidas durante o estudo formal de uma língua não apresentará a mesma ordem.

De acordo com a quarta hipótese (Input hypothesis), o aprendiz precisa estar exposto a um nível de input compreensível e oferecido em quantidade suficiente que 
não seja nem inferior e nem igual ao seu próprio nível linguístico $(i+1)$, isto é, faz-se necessário um input elevado, porém não muito superior às estruturas já adquiridas pelo aprendiz. Esse ponto merece questionamento porque o autor afirma que o $i+1$ não se apoia na gramática para ser "calculado", mas também não são fornecidos pela teoria critérios claros que permitam avaliar o que é, precisamente, o +1 .

A hipótese do input sugere que a fala é o produto da aquisição, logo não pode ser ensinada diretamente, mas é o resultado da competência construída através do input compreensível ao qual o falante tem acesso nas leituras e na compreensão oral e acrescenta que se o input é suficiente e compreensível, a gramática é fornecida. Krashen afirma que as manifestações da língua a que um falante está exposto são fundamentais, mas insuficientes para que a aquisição da L2 aconteça.

O autor sustenta a hipótese descrita acima através de algumas evidências, entre elas, a fala materna. A mãe, segundo Krashen, ao se comunicar com o filho, utiliza uma fala simplificada, acompanhada por gestos. À medida que a competência linguística se desenvolve, a complexidade do input aumenta. Pensando no ensino de L2, a fala do professor seguiria o mesmo parâmetro, isto é, a complexidade do input avançaria gradativamente com base nos estágios de aprendizado do aluno.

Outra evidência corresponderia ao período de silêncio das crianças (silence period). Trata-se do fenômeno que ocorre principalmente com crianças em situação de imersão, que, por um tempo, produzem poucas sentenças em L2, porque ouvem a língua e armazenam os "dados" que serão necessários para começar a falar. A mesma situação seria vivenciada pelo adulto que, no período inicial da aquisição, apenas recebe amostras da língua, mas não realiza produções porque a sua competência linguística em L2 está em construção. 
Outra tentativa de comprovar o papel do input se relaciona ao efeito da instrução formal, pois nos estágios iniciais de aprendizado da L2, os aprendizes adultos obtêm maior quantidade de input compreensível no ambiente de instrução formal, entretanto, nos níveis mais avançado da língua, que exigem um nível mais complexo de input, o ambiente favorecedor seria o de imersão. $\mathrm{O}$ autor analisou alguns programas canadenses de imersão em L2 em que bons resultados foram alcançados visto que foi fornecida aos alunos grande quantidade de input compreensível, apresentado dentro de um contexto e cujo foco encontrava-se na mensagem e não na forma, propiciando a aquisição.

Os programas bilíngues também ajudam a sustentar a hipótese de Krashen porque eles desenvolvem no aprendiz sólidos conhecimentos também em sua língua materna (LM) e possibilitam que ele saiba utilizar a língua para aprender e refletir sobre ideias abstratas, funcionando como facilitador da compreensão do input. Isso não aconteceria, segundo o autor, em programas que não negociam o significado da mensagem, mas traduzem a mensagem não compreendida.

Apesar das evidências discutidas pelo estudioso, sua hipótese apresenta alguns pontos questionáveis. A elaboração da definição de input compreensível cria margens para o surgimento de dúvidas em relação ao processo estabelecido em sala de aula, visto que um grupo de aprendizes nunca será homogêneo ainda que apresente características semelhantes, assim aquilo que, supostamente, é compreensível para um (ou alguns) deles, pode não ser compreensível para o(s) outro(s).

Passemos agora à quinta hipótese denominada de filtro afetivo (Affective Filter Hypothesis), que se refere aos fatores afetivos que podem influenciar a aquisição/aprendizagem da L2. Segundo ele, os aprendizes que apresentam um filtro afetivo alto, ou seja, são ansiosos, desmotivados e não demonstram autoconfiança, são impedidos de utilizar o input compreensível porque ocorre um bloqueio na mente o que 
impossibilita a sua chegada ao dito Dispositivo de Aquisição da Linguagem (ou Language Acquisition Device - $L A D$ ) ainda que tenham sido intensamente exposto à L2. Por outro lado, o filtro afetivo baixo determinado pela pouca ansiedade, alta motivação e segurança, permite que o input seja compreendido e elaborado, produzindo mudanças no sistema linguístico do aprendiz e resultando em aquisição.

De acordo com a proposta e considerando que podem ocorrer variações no filtro afetivo do mesmo falante, a condição ideal seria aquela que permitisse ao aprendiz manter pouca ansiedade, alta motivação e segurança e que possibilitasse um forte envolvimento com a mensagem, permitindo-lhe esquecer-se de que está ouvindo, lendo, escrevendo ou falando em outra língua. Segundo Krashen, a existência do filtro afetivo é responsável pelas diferenças individuais de aprendizagem verificadas entre crianças e adultos já que ele ganha força, sobretudo, na puberdade e, portanto, os adultos o apresentam em maior grau. Esses fatores que, como vimos, relacionam-se, entre outros,

à desmotivação, baixa autoconfiança e ansiedade geram um bloqueio e também explicam as diferenças no desenvolvimento da L2 entre aprendizes que foram expostos ao mesmo input.

\subsection{A hipótese do output}

O Modelo do Monitor de Krashen foi importante nos estudos de L2, entretanto alguns autores elaboraram outras teorias que confrontaram, refutaram ou questionaram a proposta do autor. Merril Swain (1985), em uma pesquisa realizada com crianças cuja LM era o inglês e que estavam aprendendo o francês como L2 em programa de imersão, 
concluiu que o uso que elas faziam da língua em outro contexto que não o escolar era menor em relação ao input que recebiam. Através do estudo, a autora estabelece possíveis hipóteses que relacionam o input ao output, afirmando que apenas a amostra da língua a que o aprendiz está exposto não garante o seu desenvolvimento linguístico

[...] embora o input compreensível possa ser essencial na aquisição da segunda língua, não é suficiente para garantir que a produção seja uma performance semelhante à do nativo. Na verdade, eu sustentarei que o input compreensível e a concomitante ênfase na interação na qual o sentido é negociado é essencial [...]. O papel das trocas interacionais na aquisição da segunda língua pode se relacionar mais com o output compreensível do que com o input compreensível ${ }^{12}$. (SWAIN, 1985: 236).

No estudo citado, os aprendizes foram submetidos a testes, tais como, entrevistas estruturadas, testes de múltipla escolha e produções escritas, que visavam a observar o desenvolvimento gramatical, observando regras de morfologia e sintaxe, o desenvolvimento discursivo, caracterizado como a habilidade de produzir e reconhecer um texto coerente e coeso e, em especial, a competência sociolinguística, definida na pesquisa como a habilidade do aprendiz de reconhecer e produzir a língua dentro de um contexto. Nos resultados alcançados verificou-se que no teste gramatical os falantes nativos obtiveram resultados significativamente melhores, assim como na competência sociolinguística, sobretudo quando ligada ao uso de uma determinada estrutura gramatical e, somente na parte dedicada à competência discursiva, as diferenças nos resultados não foram tão significativas.

O primeiro motivo que explicaria as razões pelas quais o aprendiz não alcança níveis semelhantes aos dos nativos se relacionou ao fato de que os alunos falavam pouco francês na parte "francesa" do dia, enquanto com os colegas, quando havia a possibilidade, a comunicação se realizava em língua inglesa. A segunda razão

12 "[...] is fundamental to our understanding of the role of input in second language acquisition is that although comprehensible input may be essential to the acquisition of a second language, it is not enough to ensure that the outcome will be native like performance. In fact, I will argue that while comprehensible input and the concomitant emphasis on interaction in which meaning is negotiated is essential [...]. The role of these interactional exchanges in second language acquisition may have as much to do with 'comprehensible output' as it has to do with comprehensible input." 
corresponde à utilidade do output como parte do processo de aquisição/aprendizagem da L2, pois, segundo Swain, os professores não estimulavam os alunos para produções gramaticalmente precisas e sociolinguisticamente apropriadas e como as oportunidades de promoverem a interação eram restritas, comprometia o desenvolvimento gramatical.

[...] a hipótese da interação do input é consistente com a predição de que estudantes de imersão estarão um tanto limitados no desenvolvimento gramatical em relação aos falantes nativos por causa das oportunidades relativamente restritas de se juntar a tais interações ${ }^{13}$. (SWAIN, 1985: 247)

Há diferenças substanciais entre as hipóteses de Krashen e de Swain. O primeiro considera o input compreensível crucial, pois o seu foco está no sentido e, assim, a produção oral/escrita é relevante na aquisição/aprendizagem da L2, já que é um produto que fornece amostras da língua. Por outro lado, Swain assume que input compreensível é importante porque permite ao aprendiz prestar atenção na forma e o output não é o resultado da aquisição/aprendizagem, mas faz parte do seu processo, realizando funções essenciais que não são frutos do dito LAD.

Segundo a proposta, a negociação de sentido que existe no processo de comunicação entre os falantes, neste caso, entre os aprendizes e os docentes, deve objetivar não apenas a transmissão da mensagem, mas que essa ocorra de maneira precisa, coerente e apropriada, isto é, cabe aos professores estimular os aprendizes para que aprendam a fazer modificações na produção na língua que estão aprendendo, a fim de que a mensagem atinja os objetivos a que se propõe.

Os movimentos realizados pelos falantes na tentativa de alterar sua produção correspondem à negociação de sentido e podem ser feitos para pedir esclarecimentos, buscar confirmações, retomar assuntos e fazer correções, levando ao chamado output

13 " [...] the interaction input hypothesis is consistent with the prediction that immersion students will be somewhat limited in their grammatical development relative to native speakers because of their relatively limited opportunity to engage in such interaction." 
modificado que desencadeia um processo de aquisição capaz de gerar não só a fluência na L2, mas ainda provocar a reflexão sobre a língua e a busca de uma produção coerente e precisa na transmissão da mensagem.

É importante considerar que Swain põe em relação a gramática e a comunicação sugerindo que o conhecimento gramatical não tornará, necessariamente, o falante capaz de desenvolver a sua competência sociolinguística. Podemos pensar em um falante que, apesar de conhecer as regras da L2, não consegue produzir um discurso socialmente apropriado em um determinado contexto sociocultural, talvez porque nunca tenha sido estimulado a realizá-lo. Outra consideração fundamental diz respeito à diferença entre a compreensão do input sem a análise sintática de seus elementos, ou seja, focada somente no sentido, e a realização de um output para o qual, além do nível semântico, é necessário o nível sintático. A autora comenta que o input negativo é necessário, sobretudo nas situações descritas, porque são informações básicas que permitem ao aprendiz revisar a própria produção para transmiti-la de maneira correta não apenas focado no sentido da mensagem, mas na maneira de repassá-la.

Portanto, as três funções do output estabelecidas pela autora são:

1) percepção;

2) teste de hipóteses;

3) função metalinguística e reflexiva (SWAIN, 2005: 474-477).

Na comunicação, o aprendiz pode notar sozinho ou pelo seu interlocutor que não sabe como expressar o significado exato que gostaria de falar ou escrever, assim, a própria atividade de produção na língua-alvo leva o aprendiz a reconhecer os seus problemas linguísticos. A consciência dessa falta desencadeia processos cognitivos que 
contribuem para a aquisição/aprendizagem da L2, gerando novos conhecimentos linguísticos ou consolidando os já existentes.

A segunda função refere-se ao teste de hipóteses. O output, muitas vezes, representa para o aprendiz a possibilidade de testar aquilo que imagina ser a língua-alvo. Através das próprias produções orais e escritas, o aprendiz pode confirmar ou não as hipóteses que levantou sobre as regras e sobre o uso da L2, consolidando o seu conhecimento, caso as estruturas utilizadas tenham sido suficientes para a compreensão da mensagem por parte do interlocutor, ou percebendo se a forma utilizada não foi adequada, fenômeno que ocorre quando o outro falante lhe dá sinais de que o sentido não foi compreendido e de que é necessária a reformulação. As pesquisas realizadas no estudo de Swain mostraram que os aprendizes modificam seu output em resposta a movimentos na interação como pedidos de esclarecimento ou de confirmação. Essa produção linguística provoca no aprendiz, através da análise e da gramaticalização, um processamento na memória mais profundo e elaborado das novas estruturas, de modo a transformar-se em aquisição.

O uso da língua leva o aprendiz a refletir sobre as estruturas adequadas ou não que estão sendo produzidas por ele mesmo ou pelos seus interlocutores tanto na produção oral quanto na escrita. O trabalho em conjunto, sugestão da própria autora, possibilita aos aprendizes que realizem um diálogo colaborativo que exigirá deles mesmos a percepção, o teste das hipóteses elaboradas sobre a língua-alvo e a reflexão sobre o próprio uso da língua, colocando em movimento a função metalinguística. Através dela, um aprendiz questiona o outro sobre as formas escolhidas para se expressarem na L2 e, juntos, formulam possíveis articulações ou transformações que poderiam realizar no output, isto é, podemos dizer que o pensamento que tiveram sobre a língua é concretizado por meio da própria língua. 
Com base nessas propostas, chega-se à conclusão de que entre as principais funções do professor está a de estimular os alunos a produzirem na L2 mensagens coerentes, pois essa tarefa levará o aprendiz a notar a ausência de alguma estrutura, exigirá modificações no output tais como repetições, reformulações ou decomposições e permitirá a elaboração do pensamento sobre o próprio objeto de estudo. Esse processo, como vimos, é favorecido se se realiza uma tarefa em grupo, quando o pressuposto é de que, no esforço para transmitirem uma mensagem precisa, os aprendizes estabeleçam uma interação em que é possível estimular o outro a produzir um output compreensível mesmo que sejam necessárias mudanças no discurso, provocadas pela percepção consciente da ausência de elementos que promovam a comunicação. Observamos, portanto, que através desse tipo de atividade, é possível colocar em ação os elementos que são ativados pelo output e que, além de fazer parte de todo o processo de aquisição da L2, ajudam a promovê-la.

\subsection{A hipótese da interação (Interaction Hypothesis)}

Em se tratando de hipóteses que consideram o output um importante mecanismo no processo de aquisição, os estudos de Long (1996) que se basearam em pesquisas realizadas com aprendizes de L2, também reconheceram que a produção é uma ferramenta geradora de fluência, mas evidenciaram a interação como condição indispensável para a aquisição.

Swain (2005) havia proposto que a interação, por estimular a produção dos aprendizes, era uma ferramenta interessante para ser utilizada no processo de aquisição 
de uma língua. Entretanto, sob a perspectiva de Long (1996), há outros elementos essenciais que desempenham funções na aquisição, sendo um desses exemplos, a negociação de sentido (negotiation meaning), fenômeno capaz de ocorrer tão somente durante a interação, entendida como processo em que os falantes, no esforço de se comunicarem, fornecem sinais da sua própria percepção da interlocução e que provocam "ajustes interacionais" (interactional adjustments) nas formas linguísticas, na estrutura conversacional, na mensagem ou nesses três elementos, para melhorar a compreensão entre eles. Dessa maneira, o aprendiz participa ativamente da comunicação, visando a compreender o sentido da mensagem do seu interlocutor e a fazer-se compreender.

Esse modelo de interação considera o input um fator importante na aquisição, porém, o papel por ele desempenhado é mais efetivo quando modificado através da negociação de sentido que só ocorre na interação, porque as modificações advindas desse processo tornam o input de fato compreensível e isso exige do aprendiz uma participação ativa na comunicação.

A negociação de sentido acontece por meio das repetições, das confirmações, das reformulações, do controle da compreensão e de pedidos de esclarecimento para que falhas na comunicação sejam evitadas ou para que sejam superadas as falhas que já aconteceram. Essa negociação de sentido, sobretudo quando desencadeia os já citados "ajustes interacionais" do falante nativo ou do interlocutor mais competente, facilita a aquisição, porque conecta o input, as capacidades internas do aprendiz, inclusive a atenção seletiva, e o output.

Para Long (1996), no contexto da aquisição da L2, os aprendizes recebem evidências, ou feedback positivo como também é chamada, que são os modelos de língua gramatical ou aceitável que são oferecidos pelos falantes. Por outro lado, as 
evidências negativas, ou feedback negativo, são informações diretas ou indiretas fornecidas pelos interlocutores com o objetivo de sinalizar que algum elemento da produção do aprendiz está incorreto e precisa ser reformulado.

\begin{abstract}
Isso pode ser explícito (ex. explicação gramatical ou correção declarada do erro) ou implícito (ex. falha na compreensão, correção incidental do erro em uma resposta, como checar a confirmação, que reformula o discurso prévio do aprendiz sem interromper o fluxo da conversação - casos em que a evidência negativa provê simultaneamente evidência positiva adicional [...]. Acrescentando, os colegas de conversação podem ser importantes facilitadores e modelos para o output do aprendiz e como participantes em um processo em que falantes não nativos aprendem, pelo menos, parte de uma nova gramática através da conversação. ${ }^{14}$ (LONG, 1996: 413)
\end{abstract}

Conforme a explanação do autor, as evidências positivas e negativas contribuem na aquisição/aprendizagem porque funcionam como indicadores através dos quais o aprendiz percebe se obteve sucesso na transmissão da mensagem. Elas podem ser assim resumidas:

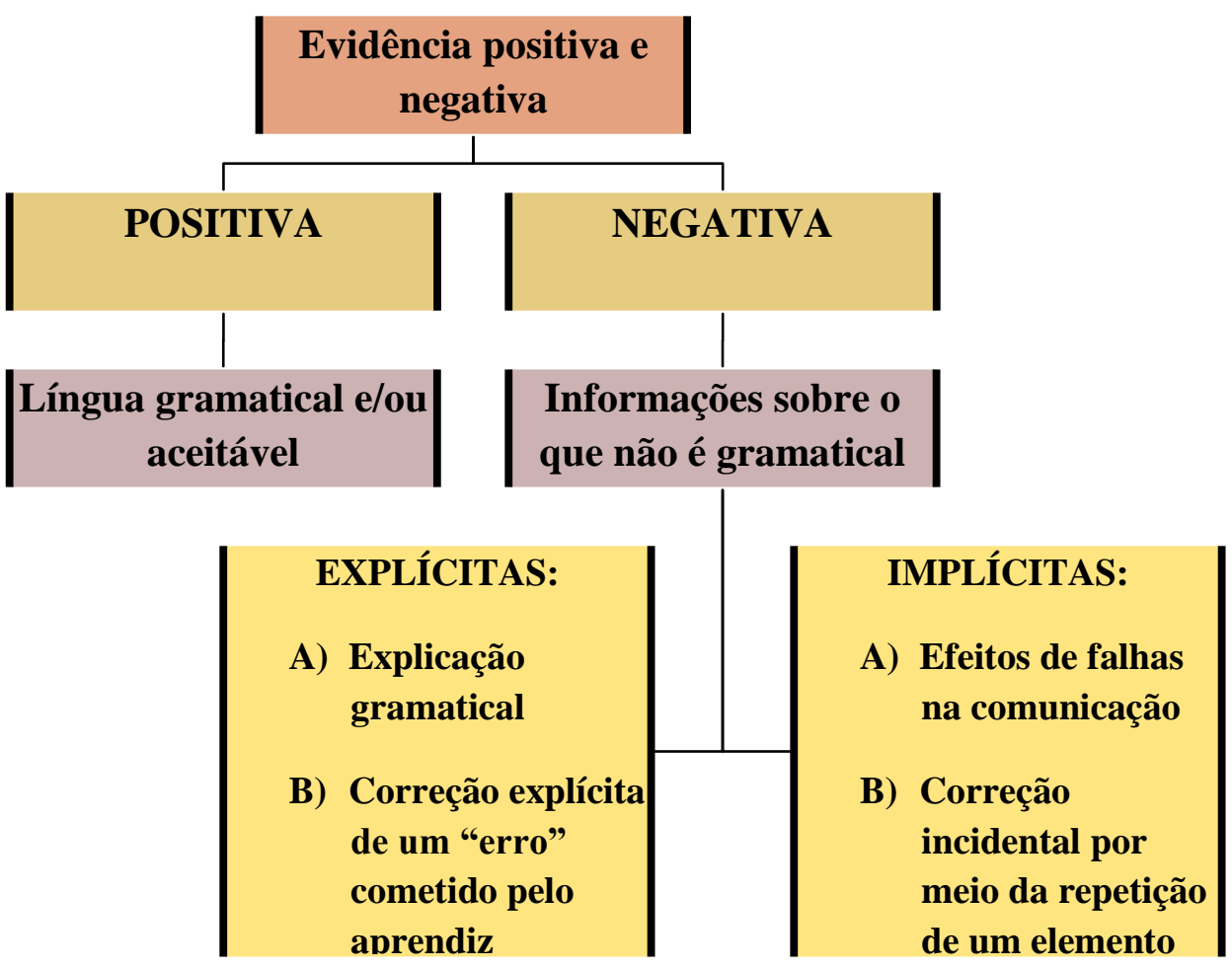

\footnotetext{
14 "This may be explicit (e.g., grammatical explanation or over terror correction) or implicit (e.g., failure to understand, incidental error correction in a response, such as confirmation check, which reformulates the learner's previous utterance without interrupting the flow of conversation - in which case, the negative feedback simultanesly provides additional positive evidence [...]. In addition, conversational partners may be important as facilitators and shapers of learner output and as participants in a process whereby nonnative speakears (NNSs) learn at least part of a new grammar by doing conversation."
} 
As ferramentas que promovem a compreensão do input e a modificação do output são movimentadas na interação, assim ela ocupa um lugar essencial na aquisição porque possibilita que o aprendiz desenvolva um papel ativo na construção da sua competência na língua-alvo, já que deve ser facilitador na transmissão de uma mensagem e negociar seu sentido com outro aprendiz, prática que melhora a compreensão e aumenta nele a sua consciência da língua. Há três conceitos mencionados por Long (1996) que são importantes para a compreensão do processo cognitivo que se desenvolve durante a interação, sendo eles:

1) a atenção (attention) - elemento cognitivo necessário capaz de focalizar e extrair alguns itens dentre os vários estímulos recebidos que permite a absorção do input;

2) a percepção ativa (noticing) - capacidade, também cognitiva, que permite ao aprendiz reconhecer um evento novo absorvido do input;

3) o foco na forma (focus on form) - a atenção do aprendiz direcionada para um evento linguístico em que forma e sentido estão ligados, ou seja, a língua está inserida em um contexto.

No processo cognitivo, em meio à manifestação da L2, a atenção permite ao aprendiz extrair dela alguns elementos entre todos aqueles aos quais foi exposto. A partir desse momento, a percepção ativa entra em movimento porque o aprendiz registra a ocorrência de algum evento novo, isto é, diferente das estruturas já adquiridas, e foca a sua atenção na forma linguística dentro do contexto em que está sendo utilizada. O aprendiz, por exemplo, recebe uma evidência negativa, e está atento à reformulação produzida pelo professor, percebendo, assim, que algo foi modificado. Trata-se da 
percepção consciente do aprendiz para registrar a ocorrência de algum evento da L2 ou do reconhecimento de um princípio que permite a conversão do input em intake, isto é, o momento da assimilação do material linguístico.

O foco na forma (focus on form) ocorre se o professor trabalha a língua como um objeto, direcionando o aprendiz a uma estrutura dentro de atividades comunicativas que promovam o trabalho concomitante da forma e do sentido. (LONG, 2006: 429). Diferentemente, o foco nas formas (focus on formS) consiste no recorte linguístico no qual as estruturas da língua são tratadas de maneira isolada e, portanto, artificialmente. O autor afirma o seguinte:

Foco na forma se diferencia de foco nas formas, que é difuso nas salas de aula de L2 e envolve uma predominante, quase exclusiva, orientação para uma série de formas linguísticas isoladas apresentadas uma após a outra, dentro de um syllabus estrutural, com sentido e comunicação relegados à margem. ${ }^{15}$ (LONG, 2006: 429).

Por meio da interação são criadas, segundo Long, as condições para que o aprendiz observe a língua (com correções, evidências positivas e negativas, reformulações, confirmações, entre outros) e isso permite obter resultados positivos e um melhor desenvolvimento das competências em L2, pois a negociação de sentido ativa processos cognitivos (atenção, percepção ativa, foco na forma) que aumentam a compreensibilidade do input.

Se o professor/interlocutor demonstra que houve falha na comunicação, o aprendiz percebe que algo está errado, reorganiza as suas hipóteses que são expressas através de outra produção até chegar à produção aceita como gramatical na língua alvo e, nesse processo, o aprendiz utiliza o input, as evidências positivas e negativas e o

\footnotetext{
15 "Focus on form differs from focus on forms, which abounds in L2 classrooms and involves a predominant, often exclusive, orientation to a series of isolated linguistic forms presented one after the other, as in a structural syllabus, with meaning and communication relegated to the sidelines". Sobre essa questão, ver também, entre outros: DOUGHTY/WILLIAMS (1998).
} 
output. As modificações realizadas para que o aprendiz aumente a compreensibilidade da mensagem levam a sua atenção seletiva ao foco na forma, pois ele percebe a língua dentro do seu contexto. Essa sequência se repete ao longo do processo de aquisição/aprendizagem e o aprendiz assimila as estruturas da língua, estabelecendo relações entre a mensagem que pretende transmitir e as estruturas usadas para expressála.

Considera-se, sob o ponto de vista interacionista, que o input é importante no processo de aquisição/aprendizagem de L2, mas insuficiente, pois algumas estruturas não são adquiridas apenas com amostras da língua às quais o aprendiz tem acesso. Long afirma que:

o input compreensível pode, na verdade, inibir o aprendizado em algumas ocasiões, porque, às vezes, é possível entender a mensagem sem entender as estruturas e todos os itens lexicais empregados pela linguagem, sem ter consciência de não ter entendido todos eles. ${ }^{16}$ (LONG, 1996: 425).

Dessa forma, a melhora da compreensão do aprendiz e o aumento da consciência dependerão das evidências negativas fornecidas pelo interlocutor no processo de interação que provocarão a necessidade de reformulação da mensagem e, para tanto, novamente, os processos cognitivos já mencionados são colocados em movimento.

\subsection{A aprendizagem implícita e explícita em L2}

Baseados nas teorias e reflexões abordadas até o momento, percebemos que muitos são os mecanismos que entram em funcionamento durante o processo de

16 "Comprehensible input may actually inhibit learning on occasion, because it is often possible to understand a message without understanding all the structures and lexical items in the language encoding it, and without being aware of not understanding them all." 
aquisição de uma L2, favorecendo e estimulando o desenvolvimento da competência linguística do aprendiz. Para refletir sobre essa competência, é importante entender a diferença entre o aprendizado implícito e o explícito, observando qual é a sua função na aquisição de outra língua, avaliando também se a gramática deve ou não ser abordada explicitamente e se o adulto pode aprender uma língua implicitamente do mesmo modo que uma criança se desenvolve na sua LM.

DeKeyser (2003), primeiramente, afirma que apesar da dificuldade em elaborar definições sobre o aprendizado explícito e implícito, foi possível chegar à seguinte conclusão:

Os sujeitos em um experimento de aprendizagem implícita geralmente têm a intenção de aprender alguma coisa, ainda que eles possam aprender algo diferente daquilo que pretendiam aprender. ${ }^{17}$ (DEKEYSER, 2003: 314).

$\mathrm{O}$ autor acrescenta que "o aprendizado implícito pode ser definido aqui como o aprendizado sem a consciência do que está sendo aprendido". ${ }^{18}$ (DEKEYSER, 2003: 314). Em relação ao aprendizado explícito, é estabelecida a seguinte concepção: “[...] o tratamento instrucional é explícito se a explanação das regras forma parte da instrução (dedução) ou se os aprendizes são orientados a observar formas particulares e tentar encontrar as regras por eles próprios (indução)."19 (DEKEYSER, 2003: 321).

De acordo com o autor, o aprendizado implícito relaciona-se ao processamento do input, sem a intenção consciente de descobrir se a informação fornecida por ele contém regras. Por outro lado, o aprendizado explícito consiste no processamento do input com a intenção de encontrar regularidades para que sejam discutidas e trabalhadas. Portanto, parece que o ponto central que diferencia os dois tipos de

\footnotetext{
17 "Subjects in experiments on implicit learning usually have the intention of learnirng something, even though they may learn something different from what they intend to learn."

18 "Implicit learning will be defined here as learning without awareness of what is being learned".

19 "...an instructional treatment is explicit if rule explanation forms part of the instruction (deduction) or if learners are asked to attend to particular forms and try to find the rules themselves (induction)".
} 
aprendizagem seja a presença da intenção consciente por parte do aprendiz no momento em que uma estrutura é aprendida/adquirida.

Concentrando-se no ensino, o autor cita, conforme lemos, os conceitos de indução e dedução, os quais não são sinônimos de aprendizado implícito, mas podem ser relacionados tanto a ele quanto à própria aprendizagem explícita, o que podemos sistematizar no seguinte quadro:

Quadro 1 - Ensino explícito e implícito

\section{Dedutivo}

\begin{tabular}{|c|c|}
\hline Ensino tradicional & Descobrimento de regras \\
\hline Utilização de parâmetros & Aprendizado da L1 pelo input \\
& \\
\hline
\end{tabular}

A aprendizagem indutiva ocorre do particular para o geral, isto é, parte dos exemplos para chegar às regras. Nos métodos tradicionais de ensino, o aprendizado é dedutivo e explícito. Se os alunos buscam encontrar regras a partir de exemplos dados em um texto, o aprendizado é indutivo, mas é explícito, pois existe a intenção consciente no descobrimento das regularidades, por outro lado, no momento em que as crianças adquirem a competência linguística na LM sem pensarem nas estruturas utilizadas, o aprendizado/aquisição é indutivo e implícito. Segundo o autor, a combinação entre dedução e aprendizado implícito é menos óbvia, mas ocorre quando "supostamente conseguem derivar um número de características da língua que está 
sendo aprendida a partir de um cenário de parâmetros e isso ocorre sem a consciência". ${ }^{20}$ (DEKEYSER, 2003: 315).

Apesar da tendência da aprendizagem adquirida implicitamente permanecer implícita e de que, por sua vez, os conhecimentos adquiridos explicitamente também continuarem explícitos, DeKeyser citando os experimentos de outro estudioso, afirma que o processo inverso também pode ocorrer.

O conhecimento aprendido explicitamente pode ser transformado em implícito no sentido que os aprendizes podem perder a consciência da sua estrutura com o tempo, e os aprendizes podem se tornar conscientes de alguma estrutura do conhecimento implícito quando tentam acessá-lo, por exemplo, aplicando-a a um novo contexto ou transmitindo-a verbalmente para outra pessoa. Nos próprios experimentos de Reber com a gramática artificial, as instruções estimulam recuperações explícitas, as quais podem conduzir à realização de um conhecimento próprio mais explícito. ${ }^{21}$ (DEKEYSER, 2003: 315).

DeKeyser ainda considera que muitos estudos recentes, como o próprio Long (1996), conforme vimos, proporcionam a compreensão de conceitos como consciência, percepção, atenção e foco na forma no aprendizado/aquisição da L2 e que essa literatura apresenta trabalhos nos quais a atenção com foco na forma desempenha um papel positivo, assim como a gramática explícita e a correção explícita do erro, ou o próprio reforço do input, pois essas ocorrências movimentam mecanismos que geram a aquisição. Em estudos e pesquisas citados por DeKeyser (2003), mostrou-se a dificuldade de encontrar medidas para o aprendizado implícito e explícito, que evidenciassem exatamente o que havia sido aprendido e, por essa razão, adverte-se que os testes devem centrar-se nas diferenças de efeitos entre orientações explícitas e

\footnotetext{
20 "[...] supposedly learners derive a number of characteristics of the language being learned from the setting of the parameter, and this clearly happens without awareness."

21 "[...] explicit learned knowledge can became implicit in the sense that learners can lose awareness of its structure over time, and learners can become aware of the structure of implicit knowledge when attempting to Access it, for example for applying it to a new contexto $r$ for conveying it verbally to somebody else. In Reber's own experiments with artificial grammars, instructions encourage explicit retireval, which may lead to making knowledge itself more explicit".
} 
implícitas no aprendizado mais do que tentar demonstrar que o aprendizado é absolutamente implícito.

Nick Ellis (1993) realizou uma experiência envolvendo a mutação das consoantes iniciais em Welsh. Três grupos foram comparados sendo que o primeiro foi exposto a exemplos numerosos de alternância de consoantes em diferentes ordens, ao acaso; o segundo, chamado de gramatical, recebeu explicações explícitas das regras em questão, seguidos pelos mesmos exemplos ao acaso e, o terceiro grupo, por sua vez, denominado de estruturado, recebeu as explicações explícitas das regras, seguidas por dois exemplos de cada uma delas e, depois, pelos mesmos exemplos dos dois primeiros grupos.

Enquanto o primeiro grupo foi o mais rápido em julgar a boa formação das sentenças que haviam visto, foi o mais devagar na generalização do conhecimento para julgar novas frases. O grupo gramatical mostrou conhecimentos explícitos sólidos das regras, mas pouca habilidade para aplicá-las no julgamento da boa formação de frases. Somente o grupo estruturado realizou bem os testes de conhecimento explícito da regra e os julgamentos gramaticais. O tratamento mais explícito, o único que levou os aprendizes à consciência de como as regras são aplicadas aos exemplos, superou os outros dois grupos. (DEKEYSER, 2003: 322).

O estudo de Bialystok (1979), um dos primeiros a realizar pesquisas nessa área, envolveu 317 alunos de francês como L2 e mostrou que os aprendizes em vários níveis de proficiência da língua realizavam bem os julgamentos gramaticais, tanto sob pressão quanto também em condições mais confortáveis. A pressão do tempo a que estavam submetidos provocou diferenças somente quando os alunos deveriam julgar detalhadamente partes de uma sentença que mostravam problemas ou quando a regra havia sido violada. $\mathrm{O}$ autor inferiu que os aprendizes realizam os julgamentos 
gramaticais a partir dos dados provenientes do conhecimento implícito e o conhecimento explícito é estimulado quando são exigidas decisões e análises específicas e detalhadas. (DEKEYSER, 2003:326)

No trabalho de DeKeyser são citados outros estudiosos que realizaram pesquisas cujo objetivo era observar nos alunos testados quais eram os efeitos das orientações explícitas ou implícitas (ALANEN, 1995), (DOUGHTY, 1991), (ROBINSON, 1996, 1997), e, em grande parte, os melhores resultados foram alcançados pelos grupos que haviam recebido instruções explícitas.

Sobre os conhecimentos implícitos e explícitos, DeKeyser afirma que os primeiros são supervalorizados “[...] enquanto o conhecimento explícito é subestimado, porque os aprendizes consideram-no difícil ou impossível de formular, mesmo que ele os ajude a decidir entre formas que competem entre si”. ${ }^{22}$ (DEKEYSER, 2003: 326).

Retomando as teorias discutidas anteriormente, podemos novamente citar Krashen (1985) o qual sugere que a aprendizagem explícita (a que, lembremos, ele chama simplesmente de aprendizagem, contrapondo-a à aquisição) nunca se transformará em aquisição, pois não há interface entre as duas maneiras de elaborar o material linguístico. Sendo assim, o papel da instrução deveria ser apenas o de prover grande quantidade de input compreensível para que possa ser gerada a aquisição, enquanto, ao contrário, o objetivo não poderia ser o de fornecer regras explícitas. Segundo a hipótese do autor a sistematização das regras e prática delas fará parte apenas da competência aprendida, provocando um distanciamento entre o conhecimento formulado sobre a língua e o seu uso.

Por outro lado, Swain (2005) considera importante o aprendizado explícito e prático, pelo menos no que diz respeito a algumas regras porque a prática, estabelecida

22 "[...] while explicit knowledge is underestimated, because learners find it hard or impossible to formulate, even when it does help them in deciding between competing forms." 
através do output preencherá o espaço entre conhecimento explícito e o uso da estrutura. Long, por sua vez, propõe que os aprendizes notam uma característica no input, ou seja, tornam-se conscientes de uma estrutura, mas as técnicas para focarem a atenção na forma (não nas formas) não são, necessariamente, explícitas. Em contraposição a isso, Rod Ellis (1997) defende que o papel do aprendizado explícito é o de ajudar o aprendiz a notar a distância entre o input e sua própria produção e a ter consciência de que é necessário realizar nela algumas modificações.

Apesar das diferentes considerações elaboradas pelos autores, DeKeyser (2003) sugere que não é possível afirmar que um tipo de aprendizado seja melhor do que o outro, mas que, talvez, a escolha entre o implícito e o explícito possa se basear nos elementos da própria língua. $\mathrm{O}$ autor elaborou um experimento utilizando-se de quatro regras morfológicas de uma língua artificial e concluiu que:

[...] regras definidas categoricamente eram melhores aprendidas em condição explícita (o que incluía apresentação tradicional das regras através de imagens/pares de sentenças), por outro lado regras 'fuzzy' 23 [...] eram um pouco melhor aprendidas em condição implícita (envolvendo exposição a imagens/pares de sentenças mas não explicação gramatical). ${ }^{24}$ (DEKEYSER, 2003: 333).

Dessa maneira, o autor formula a hipótese de que se uma estrutura é muito abstrata ou difícil de ser notada, o processo de aprendizado explícito é mais eficiente, por outro lado, o aprendizado implícito é mais adequado quando associado a elementos concretos.

Cabe lembrar que nesta pesquisa, a partir das produções escritas realizadas pelos alunos, analisaremos e compararemos os resultados obtidos antes e depois do

\footnotetext{
${ }^{23}$ Para fuzzy não há uma expressão utilizável em português. O conceito pode ser entendido como uma situação em que não são possíveis respostas do tipo "sim" ou "não".

24 "[...] clear-cut categorical rules were learned much better in an explicit condition (which included traditional rule presentation along with Picture/sentence pairs), whereas fuzzy prototypical rules (...) were learned slightly better in an implicit condition (involving exposure to picture/sentence pairs but no grammar explanation."
} 
aprendizado explícito das estruturas verbais passato prossimo e imperfetto, buscando verificar se o conhecimento explícito dessas formas favorece o seu aparecimento nas produções escritas. 


\section{Instruções explícitas: o material didático}

Como o trabalho pretende estudar os efeitos da instrução e comparar aprendizagem explícita e implícita, é necessário conhecer o tipo de instrução que os aprendizes receberam e, para tanto, analisar o material didático utilizado pelos alunos durante o período em que realizaram os testes.

Tomaremos como base os modelos operativos de análise de materiais didáticos elaborados por Semplici (2010), nos quais se dá particular atenção ao fato de que a escolha de um livro didático pelo professor deve ser orientada, sobretudo, pela identificação do público dos aprendizes que o utilizarão, buscando satisfazer tanto as suas exigências e necessidades quanto alcançar objetivos didáticos específicos. A autora sugere alguns itens que devem ser considerados para análise dos materiais que podem ser usados em sala de aula. (2010: 201).

É interessante considerar que os critérios propostos pela autora são usados para avaliar o material didático somente a partir do reconhecimento da abordagem de ensino da L2 adotada pelo livro.

O primeiro item a ser avaliado, segundo a proposta de Semplici, é se o material didático é adequado ao destinatário, pois a partir da identificação do público-alvo e das suas respectivas características e interesses (se, por exemplo, os alunos são crianças, adolescentes, adultos, ou imigrantes), é possível encontrar um livro que corresponda às suas expectativas e que os estimule no aprendizado da L2. A autora acrescenta, como segundo ponto, que os materiais também deveriam apresentar aos alunos um panorama autêntico e atual da realidade social e cultural italiana. Sobre essas características, Marco Mezzadri (2003) elaborou alguns questionamentos que podem orientar a escolha de um livro: “Quem são os destinatários? De qual idade? Qual é o nível do texto? É um 
texto de língua em geral, um livro para consulta (gramática de referência), ou um texto para ensino de língua com objetivos específicos?" 25 (MEZZADRI, 2003: 102).

No processo de avaliação de um livro didático para o ensino de uma L2, cabe também observar se é acompanhado de um manual para os professores no qual são geralmente encontradas instruções sobre o desenvolvimento das atividades, respostas de exercícios, indicações sobre teorias linguísticas, psicopedagógicas e metodológicas utilizadas. A esse respeito, em seu trabalho sobre critérios para avaliação do livro didático (LD) de língua estrangeira, Reinildes Dias afirma que o manual do professor deve apresentar

[...] de maneira clara a fundamentação teórico-metodológica na qual se apóiam as atividades propostas para processo de aprendizagem. A visão de linguagem e a de aprendizagem devem estar explicitadas com clareza, assim como os objetivos do LD como um todo e os de suas unidades e/ou módulos. (DIAS, 2009: 220).

A autora afirma ainda que os manuais não deveriam funcionar como um banco de respostas certas, mas fornecer sugestões de referências bibliográficas, sites na internet e "outros recursos disponíveis para a formação do professor e complementação da proposta pedagógica do LD” (2010: 221).

Voltando à proposta de Semplici, o terceiro ponto que a autora considera é o índice dos livros que corresponde, em geral, às premissas adotadas para sua elaboração. Um livro cuja tipologia seja, por exemplo, a nocional-funcional apresentará um índice sob a forma de tabela em que cada unidade didática indica as funções ou os objetivos linguísticos acompanhados das estruturas morfológicas e sintáticas necessárias para sua

\footnotetext{
${ }^{25}$ "Chi sono i destinatari? Di che età? Di che livello è il testo? È un testo di lingua generale, un libro per la consultazione (grammatica di riferimento o altro), un testo per l'insegnamento della lingua per fini specifici?"
} 
realização. O livro que segue o modelo comunicativo ${ }^{26}$, por sua vez, apresenta um índice voltado para as indicações de atividades comunicativas propostas pelo livro didático ou, ainda, para quais são as habilidades linguísticas que se pretende desenvolver. Se a proposta é lexical, o índice fornece informações sobre o tipo de léxico apresentado em cada unidade e sobre o âmbito semântico de referência. E ainda, se a proposta é temática, no índice são encontradas tipologias textuais variadas e heterogêneas, através das quais se objetiva observar uma série de temas selecionados. E por último, pode haver um índice que segue o método gramatical e propõe, portanto, um elenco de lições ou de temas gramaticais.

Outra característica importante de um material didático é a maneira como é dividido. Vejamos o que escreve Semplici:

\begin{abstract}
A escolha de operar através de lições ou unidades didáticas é claramente índice de uma diferença substancial de posicionamento, já que é um dos mais evidentes sinais da passagem da abordagem formalística à abordagem comunicativa, no âmbito em que se formou a unidade didática ${ }^{27}$. (2010: 203).
\end{abstract}

A unidade didática assume, por sua vez, duas possíveis características: refere-se ao objeto de aprendizagem, partindo para o desenvolvimento da competência comunicativa global ou, por outro lado, a unidade se refere à união de várias abordagens e métodos de ensino. Mezzadri (2003) comenta que a unidade didática "é hoje o modelo

\footnotetext{
${ }^{26}$ Segundo Almeida Filho, a abordagem comunicativa se mostra preocupada com o próprio aluno “enquanto sujeito e agente no processo de formação através de uma nova língua. [...] Isso significa mais força naquilo que tem sentido para o aluno, queo faz crescer como pessoa e cidadão. [...] A abordagem comunicativa não é, pois, uma bateria de técnicas ou um modelo de planejamento, mas sim a adoção de princípios mais amplos...”(2005: 80-82). Dessa maneira, o ensino não é centrado no uso puro e simples de estruturas de frases em enunciados ou simulações fora de um contexto.

${ }^{27}$ La scelta di operare attraverso lezioni, o unità didattiche è chiaramente indice diuna sostanziale differenza di impostazione, dato che è uno dei più evidenti segni del passaggio dall'approccio formalistico all'approccio comunicativo, nell'ambito del quale si è affermata l'unità didattica".
} 
operativo mais difuso nos materiais, mas nem sempre as unidades são adequadas" 28 (2010: 101). O autor acrescenta que cabe ao professor verificar

[...] alguns traços essenciais: por exemplo, se os diversos syllabus são desenvolvidos de maneira clara ou se um deles é preponderante; se as atividades são variadas, se há o objetivo de aproveitar os recursos cognitivos dos alunos, ativando-os através de percursos de preparação ao áudio ou à leitura de textos, etc. ${ }^{29}$ (2010:101).

A apresentação da gramática é outro fator importante de análise, além de ser, considerada a natureza do nosso trabalho, um dos aspectos que mais nos interessa analisar aqui. A presença de um título remete ao modelo tradicional em que a explicação da regra deve ser decorada pelo aluno e aplicada nos exercícios de conjugação e transformação de frases. A ausência de um título específico, geralmente, evidencia que o método adotado é o situacional ou funcional, para os quais a gramática deve fornecer somente os elementos para explicitar determinados atos ou funções linguísticas e tornar possível a comunicação. Esse modelo apresenta regras explícitas através de tabelas já completadas pelos autores, mas precedidas de textos que funcionam como input. Se o objetivo é levar o aluno a aprender de maneira autônoma, o texto deve promover a individualização das regras que, somente em um segundo momento, serão sistematizadas por meio da análise de textos e da realização de atividades que conduzam o aluno à compreensão na L2. Segundo Mezzadri, algumas perguntas para as quais os professores deveriam buscar respostas seriam estas: "A gramática é apresentada em contexto? De modo indutivo/dedutivo? Existem atividades de gramática comunicativa?" (2010: 103).

\footnotetext{
${ }^{28}[. .$.$] e il modello operativo oggi più diffuso nei manuali, ma non sempre le unità risultano adeguate. A$ questão de como deve ser entendida e estruturada uma unidade didática foi muito debatida entre os teóricos italianos de didática das línguas estrangeiras ou L2. Sobre o tema podem também ser consultados, entre outros, Danesi (1994) e Balboni (1994, 2002).

29 “[...] alcuni tratti essenziali: ad esempio, se i diversi sillabi vengono sviluppati in maniera chiara o se uno di essi resulta preponderante; se le attività sono variate; se si punta a sfruttare le risorse cognitive degli studenti, attivandole attraverso percorsi di preparazione all'ascolto o alla lettura dei testi, ecc."
} 
Continuando a descrição dos livros didáticos, cabe dizer que os textos presentes podem ser de dois tipos: criados ou adaptados, de um lado, e autênticos, do outro. Devido ao input gerado pelos textos, Semplici sugere que:

o texto autêntico, ainda que exija uma atenção particular na seleção dos objetivos didáticos, devido ao fato que nem toda a língua apresentada pode se transformar em objeto de aprendizagem, apresenta, de qualquer maneira, vantagens notáveis. ${ }^{30}$ (2010: 205).

Entretanto, é importante considerar que textos completos (orais ou escritos), inseridos em reais eventos comunicativos, funcionam como fonte de cultura e de variantes linguísticas, assim a seleção dos textos deve levar em conta, entre outras coisas, o contexto, a comunicação autêntica, o léxico e as expressões idiomáticas.

Também devem ser pontos de reflexão na análise dos materiais didáticos as atividades propostas, pois elas visam a reforçar a aquisição/aprendizagem da L2. É necessária a observação da eficácia de um método e perceber se, por meio do seu desenvolvimento, os objetivos estabelecidos previamente são atingidos. Dias afirma que:

[...] as atividades de aprendizagem para ler, escrever, ouvir e falar são de fundamental importância, uma vez que, por meio delas, os alunos vão se apropriar das características dos vários gêneros orais e escritos para o uso relevante da LE. As atividades devem ser variadas e envolver diferentes níveis de complexidade. (2009:218).

A última proposta de Semplici (2010: 207) refere-se às competências e habilidades linguísticas. As atividades precisam ser objetivas e poder estimular o aluno a exercitar-se para a aquisição das competências que se busca desenvolver, sejam essas culturais, comunicativas, orais, escritas, gramaticais, etc.

\footnotetext{
30 "Il testo autentico, pur richiedendo un'attenzione particolare nella selezione degli obiettivi didattici, dovuta al fatto che non tutta la lingua presentata può diventare oggetto di apprendimento, presenta comunque notevoli vantaggi."
} 


\subsection{Linea Diretta: análise de um livro didático}

No momento em que desenvolvemos a nossa pesquisa, os alunos dos cursos do Italiano no Campus utilizaram o livro didático Linea Diretta ${ }^{31}$ que é dividido em três volumes: 1A, 1B e 2. Os dois primeiros volumes são pensados para quem está no início de um percurso de aprendizagem da língua italiana, enquanto o terceiro é para o nível intermediário, segundo as recomendações encontradas no próprio livro. Acompanha o manual didático um guia para o professor, que fornece instruções de como podem ser realizados os exercícios, bem como de quais as respostas esperadas nos exercícios e, ainda, sugestões práticas sobre o desenvolvimento de determinadas atividades em sala de aula. Cabe lembrar que há com o livro também um CD com as gravações em áudio de todos os diálogos utilizados nas unidades didáticas.

No manual para os professores, não é encontrada a abordagem que o material adota para o ensino da L2; porém, conforme a proposta de Semplici (2010), somente a partir da identificação dessa abordagem é que podem ser aplicados os critérios de avaliação. Veremos a seguir que as atividades propostas no Linea Diretta exploram, com frequência, a parte oral, e diálogos em duplas, entre outros exercícios, o que provoca a falsa impressão de uma abordagem comunicativa, mas elas são realizadas com o objetivo de colocar em prática uma determinada estrutura gramatical. ${ }^{32}$

\footnotetext{
${ }^{31} \mathrm{O}$ material didático foi elaborado pelos autores Corrado Conforti e Linda Cusimano. A edição original foi publicada em 1994, na Alemanha. Os livros em análise foram impressos em 1998 na Itália e assim distribuídos em vários países. Alguns anos depois (2005), o primeiro volume foi atualizado e modificado e acabou sendo dividido em duas partes, 1A e 1B. O Linea Diretta 2 nunca foi reestruturado, assim a versão que utilizamos nesse trabalho é aquela impressa em 1997.

${ }^{32}$ Um dos aspectos que Richards e Rodgers evidenciam para estabelecer diferenças entre os métodos que se podem definir comunicativos e os que não podem ser considerados tais é justamente a maneira como os alunos são preparados para "comunicar". Enquanto nos métodos não comunicativos pressupõe-se uma rígida fase de exercitação antes da realização de atividades comunicativas, em abordagens mais comunicativas são feitas, desde os primeiros momentos, tentativas de comunicação autônoma (2001: 156). No livro Linea Diretta, verificamos a tendência de acompanhar o aluno e de levá-lo a exercitar
} 


\section{Quadro 2 - Manual para professores}

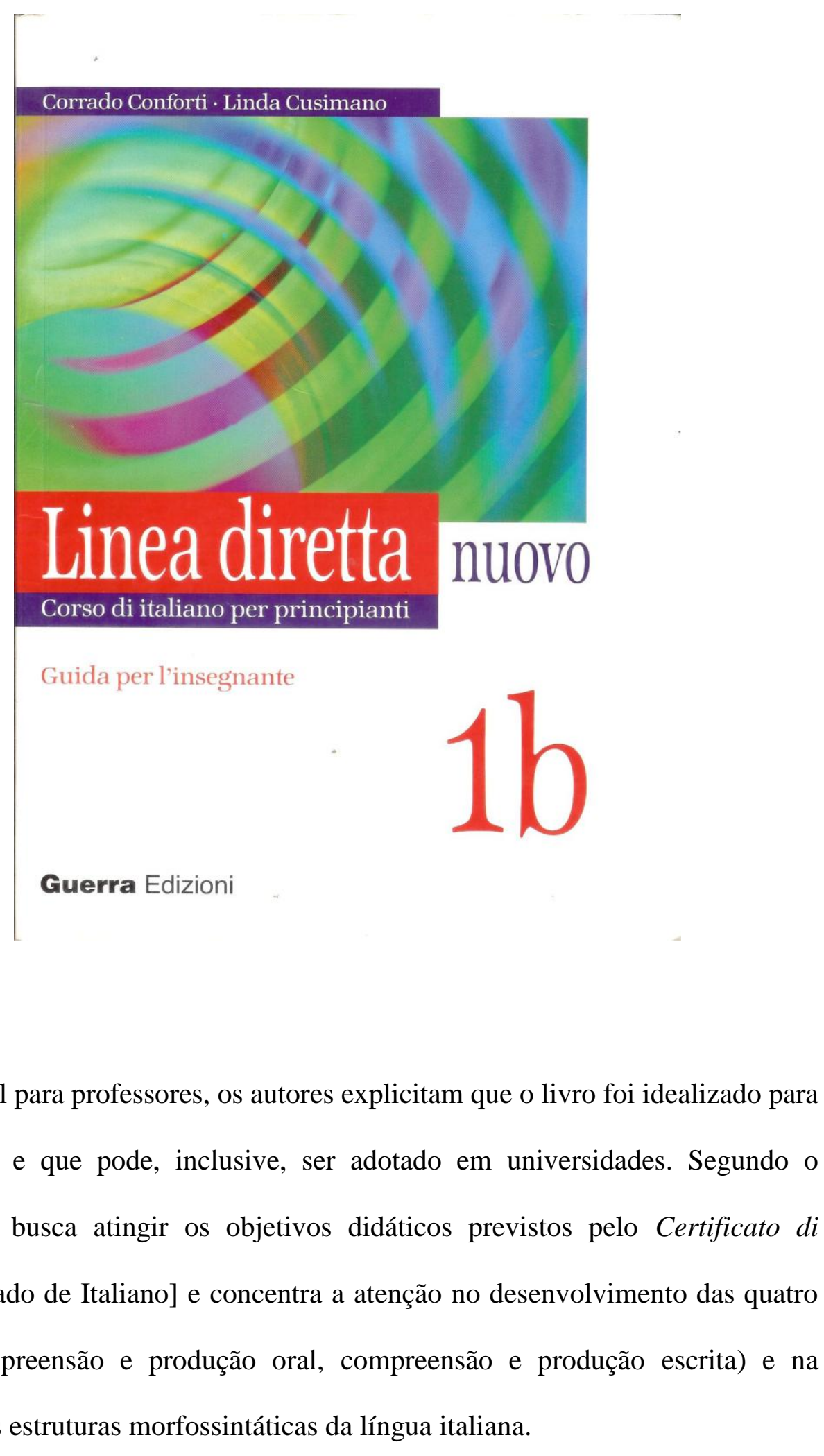

No manual para professores, os autores explicitam que o livro foi idealizado para o público adulto e que pode, inclusive, ser adotado em universidades. Segundo o manual, o curso busca atingir os objetivos didáticos previstos pelo Certificato di Italiano [Certificado de Italiano] e concentra a atenção no desenvolvimento das quatro habilidades (compreensão e produção oral, compreensão e produção escrita) e na aprendizagem das estruturas morfossintáticas da língua italiana.

estruturas gramaticais isoladas. Baseados nessa característica do manual didático, não se poderia afirmar que o livro seja comunicativo. 
Ainda no guia para os professores, os autores propõem um percurso de aprendizagem estruturado em três fases, nas quais é utilizada tanto a língua oral quanto a escrita, a saber: a atividade de recepção, análise e exercícios e, por fim, o processo da produção. As unidades didáticas começam com uma série de fotos, questionários ou pequenos textos cujo objetivo é preparar o aprendiz para o assunto da unidade didática, permitindo-lhe falar sobre o assunto e ainda ouvir informações e ideias elaboradas pelos colegas de classe. Essas atividades que representam a fase da unidade didática comumente chamada "motivação" são seguidas, em geral, pela reprodução de uma gravação em áudio em que o aprendiz ouve um diálogo que busca refletir situações do cotidiano. Na estrutura da unidade didática esse momento corresponde à fase que se costuma denominar da "globalidade" (Balboni, 1994), pois os aprendizes são colocados em contato com um input que, em um primeiro momento, é tratado como um todo. Em seguida, passa-se à fase dita de "análise" e, para tanto, são extraídas do texto de compreensão oral partes consideradas interessantes do ponto de vista gramatical e/ou funcional, pois através desses excertos são mostradas estruturas e expressões da língua italiana para que possam ser observadas "mais de perto" e analisadas. Há, logo depois, a fase de "reflexão", composta de exercícios de fixação e de produção oral que propiciam a utilização das estruturas da língua apresentadas. Em cada lição há também textos escritos, seguidos de exercícios de fixação ou de produção oral e escrita - estamos na fase de "verificação" - para que os aprendizes sejam "expostos" a um input em L2 e para que lhes sejam oferecidas oportunidades de uso da língua que estão aprendendo.

Sobre o áudio, os autores, no manual para os professores relativo ao volume $1 \mathrm{~b}$, afirmam o seguinte:

As partes de áudio do Linea Diretta nuovo são 'autênticas' no sentido que, ainda que sejam registradas em estúdio, foram realizadas por falantes cuja língua materna é o 
italiano os quais, por vezes, improvisaram diálogos exprimindo-se com sua normal fluência e entonação [...]. São os que mais se aproximam da realidade da língua falada. ${ }^{33}$

Para completar a descrição do livro didático, cabe ainda acrescentar que os dois primeiros volumes são constituídos de uma primeira parte que contém as atividades a serem desenvolvidas na sala de aula (atividades de leitura, role play, repetições, ditados, tabelas para refletir sobre formas, imagens, áudio, atividades de escrita ou produção de diálogos escritos e orais, etc,), e por uma segunda parte, na qual se encontram exercícios de fixação, sistematização, produção de frases e preenchimento de espaços, entretanto, as atividades são individuais e escritas, propostas para serem realizadas em casa. No final do livro foram elaboradas tabelas gramaticais de consulta e um glossário que inclui os lexemas na ordem em que apareceram nas unidades didáticas, uma lista em ordem alfabética dessas mesmas palavras e, por último, as soluções dos exercícios presentes na segunda seção do material.

O curso completo que, como dissemos, é chamado Italiano no Campus é composto de 8 níveis de 45 horas de aula cada um e, para cada nível, é previsto que sejam estudadas, em média, quatro unidades didáticas, com exceção do nível VI, para o qual são previstas apenas três unidades, conforme podemos verificar na tabela abaixo:

\footnotetext{
${ }^{33}$ I brani di ascolto di Linea Diretta nuovo sono «autentici» nel senso che, se pure registrati in studio, sono stati realizzati da speaker di língua madre italiana i quali, di volta in volta, hanno improvvisato delle conversazioni esprimendosi com le loro normali fluenza ed intonazione. [...] sono quelli che più si avvicinano alla realtà della lingua parlata. (2005: 6).
} 
Tabela 1 - Cursos extracurriculares e o material didático

\begin{tabular}{|c|c|c|c|c|c|c|c|c|}
\hline NÍVEL & I & II & III & IV & V & VI & VII & VIII \\
\hline VOLUME & $1 \mathrm{~A}$ & $1 \mathrm{~A}$ & $1 \mathrm{~B}$ & $1 \mathrm{~B}$ & 2 & 2 & 2 & 2 \\
\hline UNIDADES & $1-4$ & $5-8$ & $1-4$ & $5-8$ & $1-4$ & $5-7$ & $8-11$ & $12-15$ \\
\hline
\end{tabular}

Quadro 3 - Livro Linea Diretta

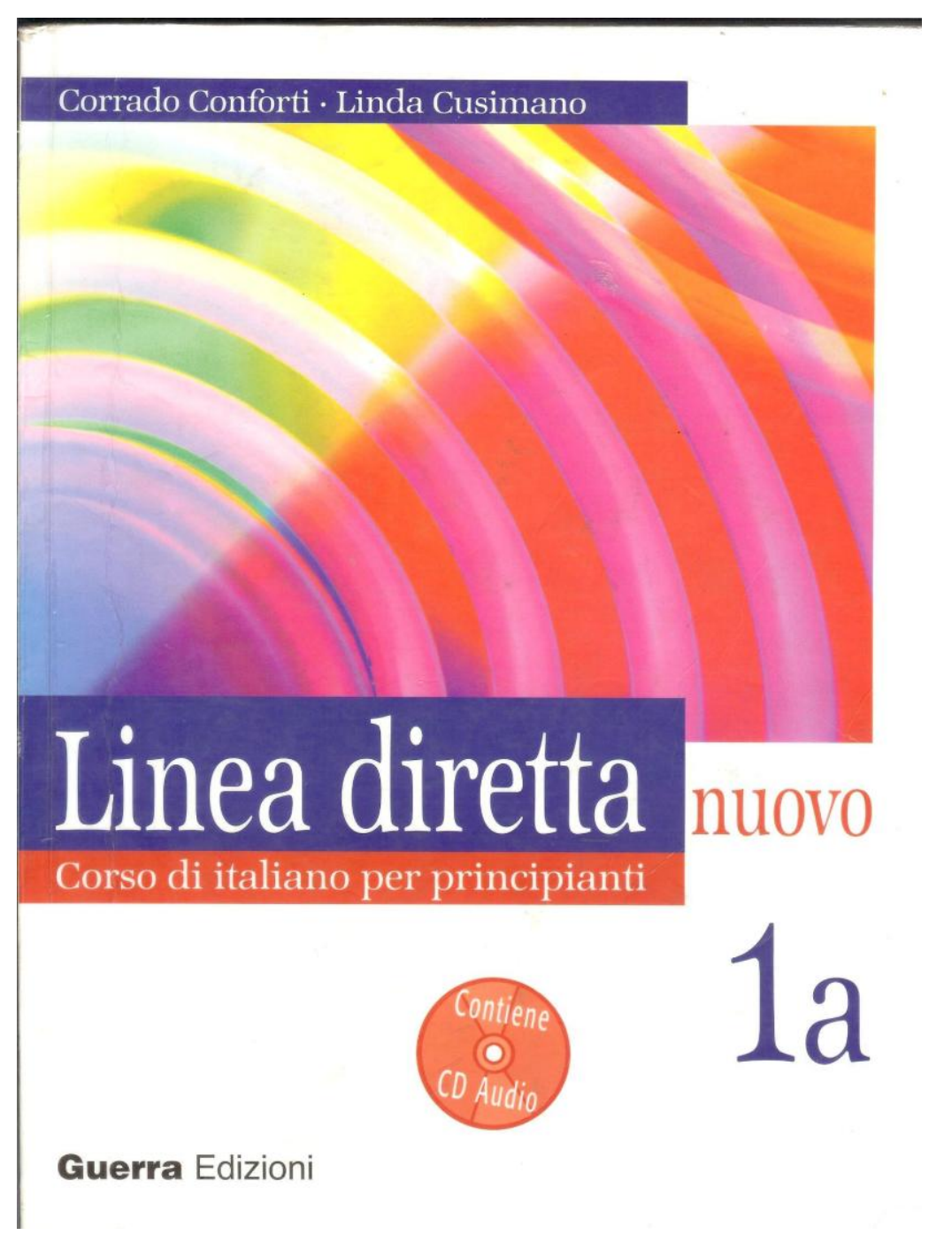


O segundo volume do livro didático (o livro 2) caracteriza-se pela grande quantidade de textos para leituras, a partir dos quais foram elaboradas atividades, e pelas tarefas propostas a partir do áudio, característica predominante nos livros 1A e 1B, porém, os exercícios de sistematização e fixação, também pensados para serem realizados individualmente e por escrito, encontram-se em um livro separado - o chamado "libro degli esercizi" (livro dos exercícios).

\subsubsection{Passato prossimo e imperfetto no livro didático}

Uma análise mais detalhada do livro didático Linea Diretta será dirigida aos capítulos do livro em que são abordados especificamente os tempos verbais objeto de nossa pesquisa: passato prossimo e imperfetto. Como já mencionamos, para observar o efeito da aprendizagem implícita e explícita dos tempos mencionados, escolhemos aplicar testes nos alunos dos níveis II, III, IV e V, visto que no nível II a estrutura do passato prossimo é ensinada explicitamente, e que o mesmo ocorre também com o imperfetto, entretanto, apenas no final do nível II.

O tempo verbal passato prossimo é introduzido a partir da unidade didática 5 do livro Linea Diretta 1A. O título é: "Ho saputo che hai fatto un viaggio" [Soube que você fez uma viagem] e já apresenta a estrutura verbal a ser estudada, pois remete a um tempo verbal que, explicitamente, os alunos ainda não estudaram. Como o tema proposto para a unidade didática é a viagem, para iniciar o assunto, o livro propõe na fase de motivação algumas fotos que se referem a regiões italianas e sugere questões relativas às viagens para discussão. 


\section{Quadro 4-O passato prossimo}

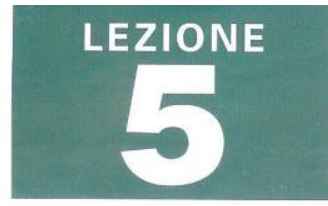

(1)

Ho saputo che hai fatto

un viaggio

\section{PER INIZIARE}

Guardate la pubblicità di queste regioni. Quale vi piacerebbe visitare? Perché? Conoscete altre regioni italiane? Sapete che cosa c'è da vedere?

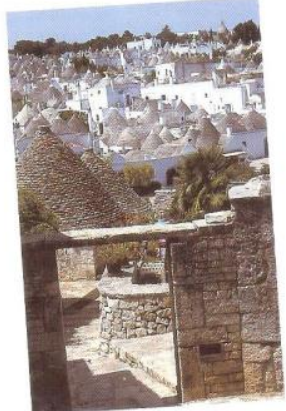

Puglia Viaggio romantico nel passato fra trulli e borghi medioevali

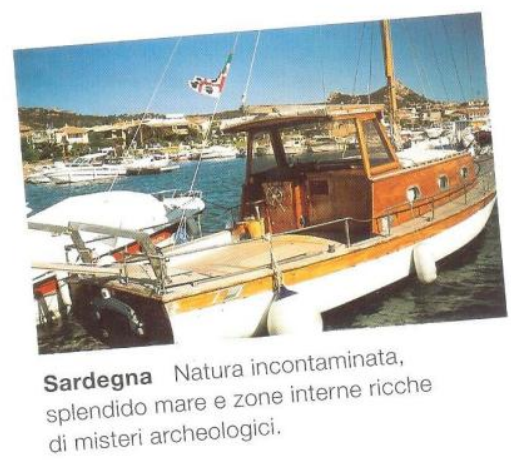

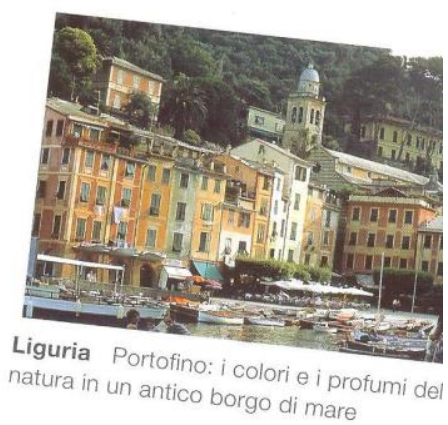

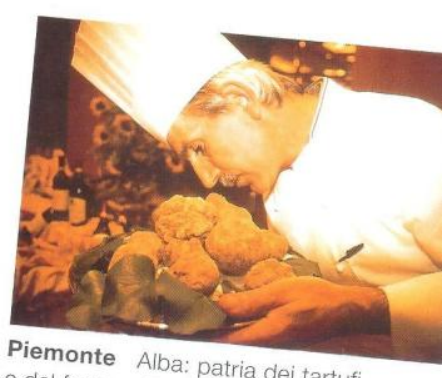
e del famoso Barbera

Fonte: Linea Diretta 1a, p. 54

Em seguida, está previsto que os alunos ouçam uma gravação em áudio na qual dois falantes conversam sobre uma viagem que um deles realizou. A compreensão oral é verificada por meio de um teste de múltipla escolha no qual aparecem sempre verbos no passato prossimo. A partir dessa atividade, o diálogo é dividido em partes selecionadas com base nas estruturas ou expressões consideradas relevantes para os objetivos da unidade didática. 


\section{Quadro 5 - Compreensão de áudio}

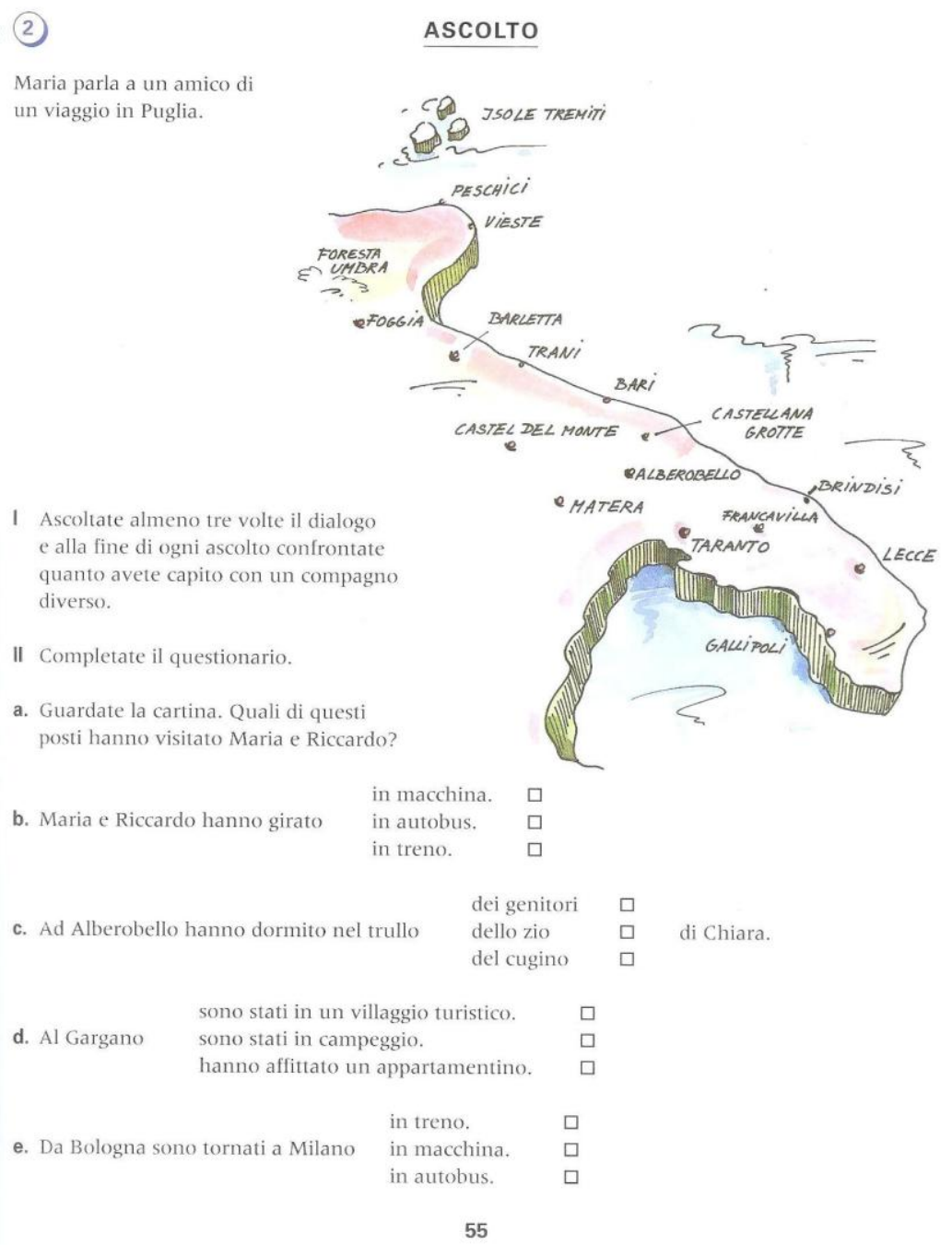

Fonte: Linea Diretta 1a, p. 55

A primeira parte do diálogo é acompanhada por uma tabela que deve ser completada pelo aprendiz. A tabela mostra que o passato prossimo é formado por um auxiliar essere ou avere e pelo particípio passado do verbo principal e pode ser completada extraindo as formas verbais do trecho de diálogo escolhido, levando o aprendiz a refletir sobre a composição da marca perfectiva e permitindo-lhe, a partir da observação dos exemplos, deduzir quais seriam as possíveis regras que os orientariam na escolha no verbo auxiliar. Retomando os princípios de DeKeyser (2003), entendemos 
que se trata de um modelo de aprendizagem explícita de tipo indutivo, visto que os aprendizes partem das formas verbais recortadas do áudio com o objetivo consciente de encontrarem as regularidades da língua. Observemos como é apresentada a tabela no livro didático:

Quadro 6 - Estrutura do passato prossimo

\begin{tabular}{|ll|}
\hline Infinito & passato prossimo \\
Trovare & ho trov__ \\
Sapere & \\
Partire & sei part__ \\
Prendere & \\
Fare & \\
Essere & \\
\hline
\end{tabular}

Fonte: Linea Diretta 1a, p. 56.

Partindo das teorias sobre aquisição/aprendizagem da L2 e apoiando-nos, principalmente, na hipótese de Long (1996), observamos que o esquema proposto pelo material didático é um clássico exemplo de focus on forms, visto que realiza um recorte da língua explorado fora do contexto em que estava inserido, o que pode não favorecer o desenvolvimento da competência comunicativa. ${ }^{34}$

Em seguida é proposto um exercício de formação de frases a partir de um modelo que simula um diálogo entre dois aprendizes e sugere a utilização do passato prossimo. O exercício fornece dois verbos no infinitivo, já acompanhados por objetos, de modo que do aprendiz exige-se apenas a conjugação do infinitivo no passato prossimo, de modo a formar uma pergunta e uma resposta. $\mathrm{O}$ exemplo que deve instruir para a realização do exercício é apresentado da seguinte maneira:

\footnotetext{
${ }^{34}$ Sobre o focus on forms, ver cap. 2 desta dissertação (pág. 51).
} 


\section{Quadro 7 - Atividade de passato prossimo - exemplo}

Fare un bel viaggio [fazer uma bela viagem] - Stare in Puglia [estar na Puglia]

- Ho saputo che hai fatto un bel viaggio. [Soube que fez uma bela viagem]

- Sì, sono stato/stata in Puglia. [Sim, estive na Puglia]

Fonte: Linea Diretta, p. 56

Segundo a indicação do enunciado, os verbos sublinhados deveriam ser substituídos repetidamente, entre outros, pelos seguintes:

\section{Quadro 8 - Atividade de passato prossimo}

Essere in Italia [estar na Itália] - Frequentare un corso d'italiano [frequentar um curso de italiano]

Fare un viaggio [fazer uma viagem] - andare alle Maldive [ir para as Maldivas]

Fonte: Linea Diretta, p. 56

Nessa fase de análise e reflexão, é utilizada a técnica de exercícios estruturais, que são retomados novamente na mesma unidade didática e funcionam, sobretudo, como produções controladas da forma linguística em análise.

Ainda nessa unidade, há o ditado de uma parte do diálogo inicial em que os espaços devem ser preenchidos com o passato prossimo ou somente com o verbo auxiliar conjugado. Seguem-se outros exercícios de formação de frases, sempre para serem executados em duplas

Em uma seção chamada de E adesso tocca a voi [E agora é com vocês] que faz parte, inclusive, de todas as unidades didáticas, há três sugestões de produções orais/escritas. A primeira é uma entrevista, seguindo a proposta do diálogo inicial da 
unidade. O próprio enunciado sugere a utilização da estrutura abordada, pois nele encontramos verbos no passato prossimo que se pede sejam usados na produção. Tratase de uma interação em que um dos aprendizes quer saber do outro onde passou as férias, como foi e o que fez, enquanto o outro responde as perguntas.

\section{Quadro 9 - Atividade oral}

Intervistate un compagno. Domandategli dove è stato in vacanza l'ultima volta, come c'è andato, che cosa ha visto, che cosa ha fatto.

[Entrevistem um colega. Perguntem-lhe onde passou as últimas férias, como foi até lá, o que viu, o que fez]

Fonte: Livro Linea Diretta 1a, p. 58.

A segunda produção, a ser desenvolvida individualmente, sugere ao aluno a produção escrita de um texto sobre a cidade ou a região em que mora, porém, não exige a utilização da estrutura abordada na unidade. Essa proposta surge a partir de uma leitura sobre lugares interessantes a serem visitados em que são ensinadas duas estruturas específicas: o si impersonale e o si passivante.

\section{Quadro 10 - Atividade escrita}

Scrivete un piccolo testo sulla vostra città o sulla vostra regione. Perché può essere interessante per un turista? Che cosa c'è da vedere? Che cosa si può fare?

[Escrevam um pequeno texto sobre a cidade ou região de vocês. Por que pode ser interessante para um turista? O que há para ver? O que se pode fazer?]

Fonte: Livro Linea Diretta 1a, p. 60.

Essas atividades são motivadas pelo input recebido desde as fases de motivação e globalidade, nas quais, como já dissemos, foram desenvolvidos temas que se relacionavam a viagens, descrição de lugares, entre outros, e estimulam a produção oral. O diálogo colaborativo, desenvolvido, em especial, na primeira atividade, favorece a negociação de sentido e a reflexão sobre a própria língua, mecanismos importantes para 
a aquisição/aprendizagem da L2, visto que levam os aprendizes a testarem as suas hipóteses na transmissão da mensagem, com o objetivo de se fazerem entender e de compreenderem a produção do interlocutor. Observamos que, no decorrer da unidade didática, são propostos exercícios que partem do output controlado até chegar às produções mais livres e esse percurso tende a desenvolver a comunicação a partir das estruturas gramaticais que foram fornecidas.

Em seguida, a unidade didática aborda a questão do acordo de gênero e número com o sujeito que precisa ser utilizado com o particípio passado quando o auxiliar é o verbo essere em expressões como mi sono piaciuti/-e [me agradaram] ou mi è piaciuto/$a$ [me agradou].

Finalizando a unidade, há vários depoimentos breves de pessoas que escrevem ou pedem conselhos em um site de viagem, geralmente relatando experiências vividas. Concernente a esse aspecto, o livro segue uma das indicações observadas por Semplici (2010), pois os textos são autênticos, completos e coerentes com o contexto da unidade didática, apresentando a variedade linguística informal e, no que diz respeito à temática, um fenômeno da sociedade. Entretanto, as perguntas apoiadas na leitura do texto, apesar de exigirem a compreensão do input recebido, não estimulam a estruturação de um output muito elaborado o que, por sua vez, não permitirá a realização de todas as suas funções - percepção, teste de hipóteses e função metalinguística e reflexiva -, visto que podem ser respondidas apenas com um nome, como podemos verificar:

\section{Quadro 11 - Compreensão textual}

a. Chi ha prenotato un viaggio organizzato? [Quem reservou uma viagem organizada?]

b. Chi ha fatto una prenotazione in Internet? [Quem fez uma reserva na Internet?]

c. Chi chiede consigli ad altre persone? [Quem pede conselhos para outras pessoas?] 
d. Chi ha avuto un piccolo problema in vacanza? [Quem teve um pequeno problema na viagem?]

e. Chi ha viaggiato da solo? [Quem viajou sozinho?]

Fonte: Livro Linea Diretta 1a, p. 63.

Logo após, propõe-se uma atividade de sistematização sobre a forma do passato prossimo, em que os aprendizes observam as ocorrências desse tempo verbal no texto e as copiam dividindo-as em duas colunas, uma com o auxiliar essere e outra com o auxiliar avere, sem nenhuma reflexão aparente sobre a tarefa realizada.

O penúltimo exercício é formado por perguntas a serem completadas com os verbos sugeridos no tempo abordado na unidade, compondo, assim, a fase de verificação. A terceira produção oral/escrita não se relaciona apenas com o tempo verbal abordado, mas se refere ao tema apresentado no texto, pedindo aos alunos que conversem sobre seus hábitos na internet e que escrevam um conselho para uma viagem e, ainda, o resumo de uma viagem realizada.

\section{Quadro 12 - Propostas de produções: oral e escrita}

a. Navigate anche voi in Internet? Se sì, quante ore alla settimana? [Vocês também navegam na Internet? Se sim, quantas horas por semana?

b. Avete voi dei consigli da inviare a viaggeria.it? Scrivete un breve resoconto di viaggio. [Vocês têm conselhos para enviar ao viaggeria.it? Escrevam um breve resumo de viagem]

Fonte: Livro Linea Diretta 1a, p. 63

Ao final da unidade, novamente, percebemos que para atingir o objetivo de desenvolver a competência comunicativa tanto oral quanto escrita, foram sugeridas nas fases de análise e reflexão, atividades mais controladas, conforme observado nos exemplos transcritos, mas que ao final apresentavam traços menos controlados. Durante a conversação, os alunos procuram compreender e fazer-se entender e, a fim de alcançar 
esses objetivos, realizam ajustes interacionais (interactional adjustments) na mensagem ou na forma linguística adotada. Esse movimento de negociação de sentido que ocorre na interação permite o funcionamento dos mecanismos cognitivos da atenção, da percepção ativa e do focus on form favorecendo a aquisição/aprendizagem da L2 e levando a transformar a aprendizagem explícita em uso, o que, segundo a já citada teoria do output de Swain (1995, 2005), só acontece na produção.

As atividades presentes na unidade didática são variadas e buscam desenvolver as habilidades de compreensão e produção oral e de compreensão e produção escrita, porém, percebemos que a produção escrita fez parte apenas da fase de verificação, apesar de ser tão importante quanto as outras, já que possibilita ao aprendiz refletir sobre as estruturas aprendidas para aplicá-las no ato comunicativo.

Na parte final do livro, encontram-se exercícios de fixação e sistematização e os alunos precisam escolher entre os verbos auxiliares essere e avere, saber formar o particípio passado dos verbos (inclusive irregulares), preencher frases e textos com o passato prossimo, formar perguntas também com a estrutura saliente. Na tabela gramatical de consulta, explica-se a formação desse tempo verbal, evidenciando que o uso do verbo auxiliar implica fazer a concordância ou não em gênero e número com o sujeito. Além disso, há uma tabela mostrando o particípio passado de alguns verbos irregulares, pois esses não seguem a regra do particípio regular. Não existe nenhuma explanação ou comentário sobre a utilização desse tempo verbal ou uma comparação entre o tempo passato prossimo e o tempo presente, estrutura abordada por um semestre inteiro no primeiro nível da língua e que, como vimos, corresponde a quatro lições. 


\section{Quadro 13 - Preenchimento de espaços}

14. Completate con il passato prossimo dei verbi fra parentesi.

a. Laura (prendere) la patente e (comprare) una macchina nuova.

b. Marisa e Gabriella (andare) al bar e (prendere) un gelato.

c. Noi (prendere) l'autobus e (scendere) alla seconda fermata.

d. Io (restare) a casa, (leggere)

il giomale e (scrivere) una lettera.

e. Io (andare) in vacanza in Toscana, (visitare) Siena e (fare) molte fotografie.

Fonte: Linea Diretta 1a, p. 161. 


\section{Quadro 14 - Estrutura do passato prossimo}

Schematizzazione del passato prossimo

Coniugazione con avere

\begin{tabular}{|lll|}
\hline (io) & ho & parlato \\
(tu) & hai & avuto \\
(lei) & & sentito \\
(lui) & ha & visto \\
(Lei) & & fatto \\
(noi) & abbiamo & \\
(voi) & avete & preso \\
(loro) & hanno & \\
\hline
\end{tabular}

Coniugazione con essere

\begin{tabular}{|c|c|c|}
\hline (io) & sono & \\
\hline (tu) & sei & $\begin{array}{l}\text { andato } \\
\text { andata }\end{array}$ \\
\hline (Lei) & è & \\
\hline (lui) & \multirow{2}{*}{ è } & andato \\
\hline (lei) & & andata \\
\hline (noi) & siamo & \\
\hline (voi) & siete & $\begin{array}{l}\text { andati/ } \\
\text { andlate }\end{array}$ \\
\hline (loro) & sono & \\
\hline
\end{tabular}

\section{Verbi irregolari al participio passato}

Molti verbi, soprattutto in -ere, hanno un participio passato irregolare.

Ecco alcuni esempi:

\begin{tabular}{|c|c|c|c|c|c|}
\hline aprire & $\rightarrow$ & aperto & rimanere & $\rightarrow$ & rimasto \\
\hline chiedere & $\rightarrow$ & chiesto & rispondere & $\rightarrow$ & risposto \\
\hline chiudere & $\rightarrow$ & chiuso & scendere & $\rightarrow$ & sceso \\
\hline dire & $\rightarrow$ & detto & scegliere & $\rightarrow$ & scelto \\
\hline essere & $\rightarrow$ & stato & scoprire & $\rightarrow$ & scoperto \\
\hline fare & $\rightarrow$ & fatto & scrivere & $\rightarrow$ & scritto \\
\hline leggere & $\rightarrow$ & letto & spendere & $\rightarrow$ & speso \\
\hline hettere & $\rightarrow$ & messo & vedere & $\rightarrow$ & visto \\
\hline & $\rightarrow$ & offerto & venire & $\rightarrow$ & venuto \\
\hline endere & $\rightarrow$ & preso & & & \\
\hline
\end{tabular}

Fonte: Linea Diretta 1a, p. 163.

$\mathrm{Na}$ unidade sucessiva não há atividades ou exercícios que retomem esse tempo verbal. A partir do léxico relativo a cardápios, restaurantes, hábitos alimentares, comida italiana, são apresentados aos alunos os adjetivos possessivos, o pronome partitivo ne e o artigo partitivo no singular. Do ponto de vista comunicativo, as funções linguísticas que se apresentam são pedir ou fornecer explicações, expressar sugestões e conselhos. 
Na unidade 7, o assunto discutido é a rotina. Um dos participantes do diálogo está de férias e relata ao outro o que faz durante o dia ou à noite. As estruturas morfossintáticas evidenciadas são os verbos reflexivos no tempo presente e o presente progressivo, além de uma introdução ao comparativo. Por outro lado, desenvolvem-se as seguintes funções linguísticas: fazer um convite, cumprimentar e desejar felicidades por um acontecimento, pedir informações e fazer propostas. Novamente, o passato prossimo não é retomado nem através de exercícios nem em atividades de conversação o que ocorrerá no livro didático somente no início do segundo nível. Entretanto, no livro de exercícios, a unidade 7 apresenta três atividades referindo-se ao passado. A primeira é um texto que deve ser completado escolhendo o tempo adequado, se passato prossimo, presente progressivo ou o presente. No outro exercício são encontrados verbos no passato prossimo, mas o objetivo, na verdade, é encaixar em uma carta algumas conjunções faltantes e, por fim, no terceiro exercício propõe-se a formação de frases fazendo uma combinação entre presente e passato prossimo com o uso das conjunções.

Na unidade 8, introduz-se uma nova estrutura verbal: o imperfetto. A partir do título, os aprendizes já se deparam com o tempo novo "Non lo sapevo" [Não sabia]. A atividade inicial é composta por três pequenos textos que indicam cursos para serem feitos e as perguntas propostas incitam o uso do passato prossimo "Avete già frequentato uno di questi corsi? C'è un corso che vi piacerebbe frequentare ancora?" [Vocês já frequentaram um desses cursos? Há um curso que vocês ainda gostariam de frequentar?] 


\section{Quadro 15 - O imperfetto}

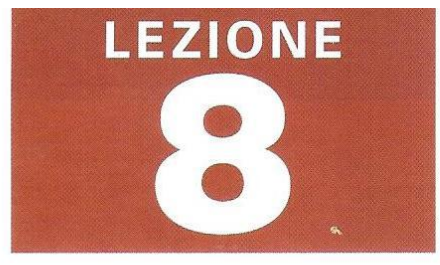

(1)

\section{Non lo sapevo!}

PER INIZIARE

Avete già frequentato uno di questi corsi? C'è un corso che vi piacerebbe frequentare ancora? Parlatene con un compagno.

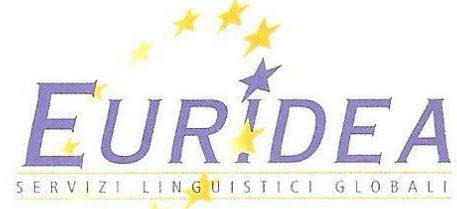

\section{Scuola di italiano per stranieri}

Corsi a Bologna, corsi al mare, corsi in agriturismo. Lezioni di lingua italiana a domicilio, presso la nostra sede o presso la sede di enti, associazioni, aziende che ne fanno richiesta.

Corsi di conversazione libera in italiano su argomenti a scelta. Un ottimo rapporto qualità - prezzo, tra i migliori attualmente riscontrabili sul mercato.

\section{Corso di Cucina}

Il corso di cucina tenuto da alcuni anni a Roncegno presso la Casa di Salute Raphael è nato dalla richiesta degli ospiti della Casa di conoscere e poter sperimentare direttamente «con le mani in pasta» $\mathrm{i}$ metodi di preparazione degli alimenti. I corsisti, ospitati nelle ampie cucine della Casa, seguono e partecipano direttamente alla preparazione dei piatti vegetariani più vari. Lo Chef Luigi segue personalmente lo svolgersi di tutto il corso.

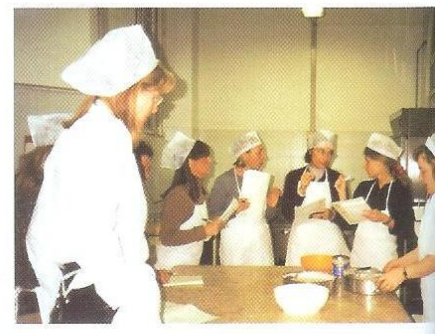

Il corso è aperto a tutte le persone interessate. Costo del corso e della pensione completa in stanza doppia dalla cena del martedì al pranzo del sabato compresi è di euro 370,00. Supplemento per la stanza singola: euro 30,00. Per gli esterni che non alloggiano presso la Casa il costo di partecipazione al corso è di euro 215,00, pasti inclusi.

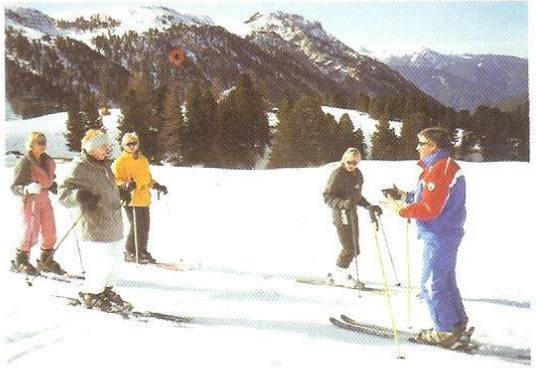

Fonte: Linea diretta 1a, p. 84.

\section{La scuola sci Pampeago}

dà il benvenuto agli appassionati dello sci. Corsi sci alpino Corsi per bambini

Corsi carving

Corsi snowboard

Corsi neve fresca

Corsi per aspiranti maestri

Corsi domenicali per gruppi preorganizzati Lezioni individuali ( $1-4$ persone)

Gara settimanale 
Há um diálogo em que um dos personagens relata ao outro o que fez durante as férias. O teste de verdadeiro ou falso proposto em seguida é formado por frases no passato prossimo.

Quadro 16 - A compreensão auditiva - imperfetto

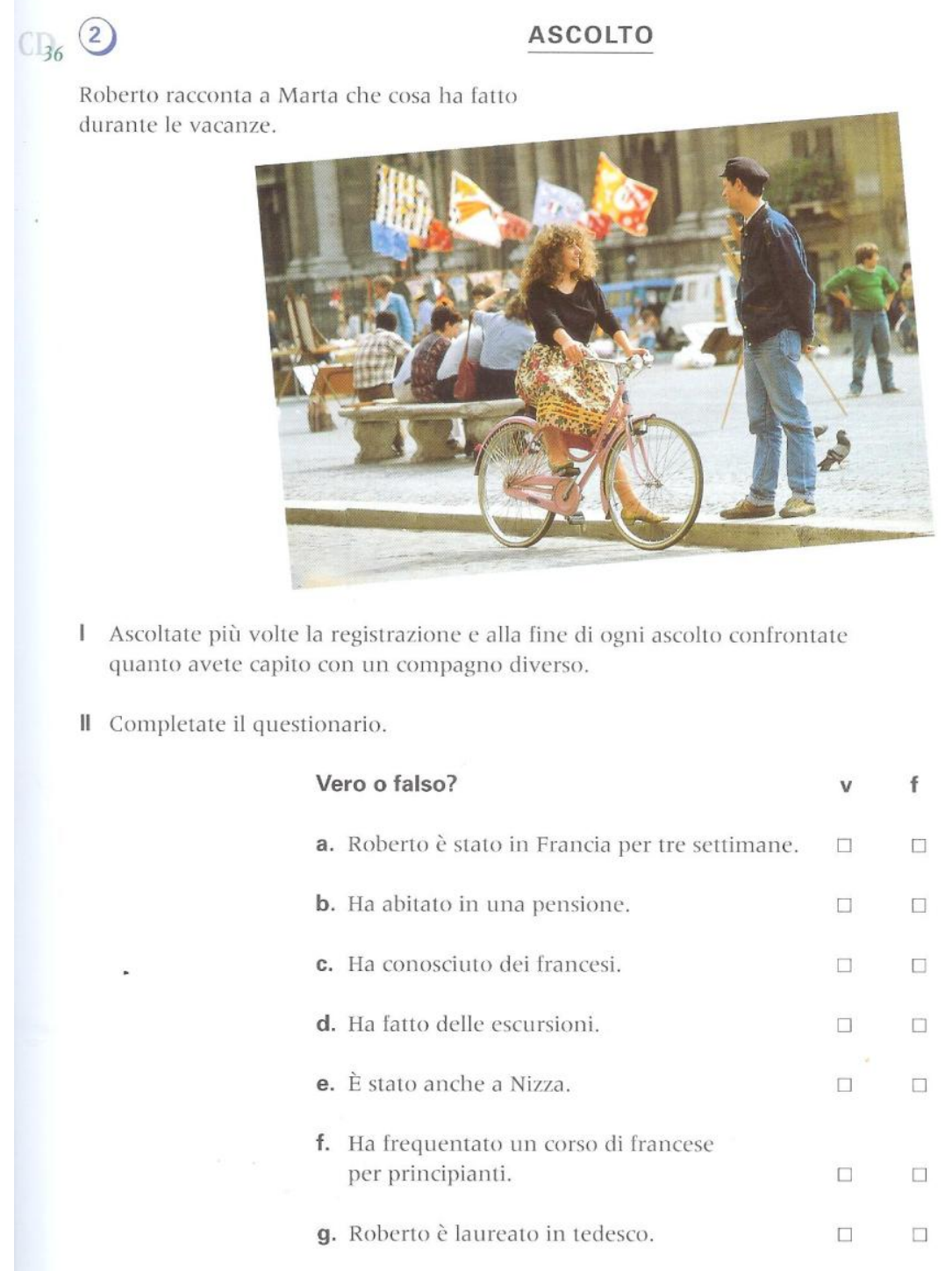

Fonte: Linea diretta 1a, p. 85. 
Seguindo a metodologia do material didático, o diálogo é dividido em partes e, na primeira delas, o uso do passado é retomado através de um pequeno texto com espaços:

\section{Quadro 17 - Diálogo}

- Ciao, Maria. [Oi, Maria]

- Sì, sono stato in Francia per un mese. [Sim, estive na França por um mês]

- Sì, sì, molto bello. [Sim, sim, muito bonito]

- Ho frequentato um corso di francese. [Frequentei um curso de francês]

Fonte: Linea Diretta 1a, p. 86.

O passato prossimo é retomado, mas não de forma isolada, pois no primeiro texto o aluno pode completar as perguntas de maneira indutiva, isto é, através da observação das respostas ele pode formular as frases que seriam adequadas e, somente em um segundo momento, insere-se novamente o áudio para que as duas respostas sejam confrontadas.

No segundo exercício, propõe-se a formação de duplas de aprendizes para repetir diálogo substituindo nas respostas os lugares, a duração da estadia e as atividades desenvolvidas, como podemos observar: 


\section{Quadro 18 - Diálogo em duplas}

a. Roma / due settimane / visitare la città [Roma / duas semanas / visitar a cidade]

b. Spagna / dieci giorni / fare un giro con la motocicletta [Espanha / dez dias / fazer um passeio de moto]

Fonte: Linea Diretta 1a, p. 86.

A partir da segunda parte do diálogo, introduz-se o imperfetto que é utilizado pelo personagem para descrever o curso por ele realizado. O livro apresenta um quadro para completar com os verbos que podem ser extraídos do diálogo evidenciando o novo tempo verbal e a sua concordância no verbo impessoal esserci [haver], tratando-se novamente de uma atividade de focus on forms, o que havia sido feito nas instruções sobre o passato prossimo:

Quadro 19 - A estrutura do imperfetto

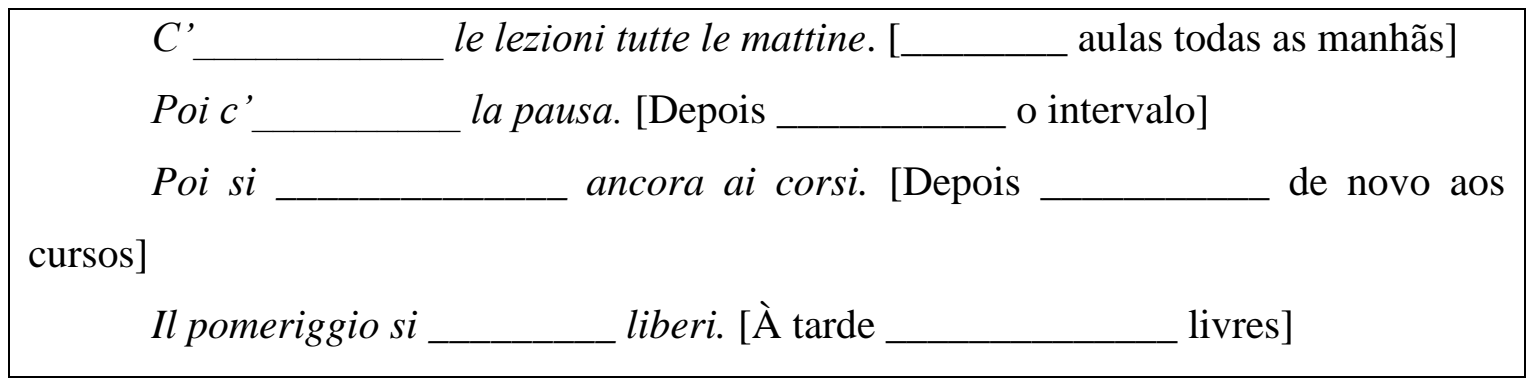
Fonte: Linea Diretta 1a, p. 87.

O material didático não fornece diretamente as regras na unidade didática, mas por meio do recorte dos exemplos, o aprendiz pode analisar conscientemente o input recebido com o fim de encontrar as regularidades da estrutura indutivamente, as quais também podem ser consultadas no apêndice gramatical que se encontra no fim do livro.

Na fase de análise e reflexão, há um exercício de perguntas e respostas em que os verbos são propostos no infinitivo e devem ser transformados pelos alunos em imperfetto, seguindo o modelo que haviam completado anteriormente.

A seguir, os aprendizes observam e podem completar com o verbo faltante duas frases extraídas do mesmo trecho, cujo foco gramatical é a oposição entre os tempos do 
passado, passato prossimo e imperfetto, os quais são associados, respectivamente, à expressão de uma ação pontual e a uma marca de frequência. Nesse esquema, em particular, o uso desses tempos é descrito explícita e tradicionalmente:

Quadro 20 - Uso do passato prossimo e imperfetto

Imperfetto $=$ di solito, in generale [frequentemente, geralmente]
Passato prossimo $=$ ogni volta, in particolare [cada vez, em especial]

Fonte: Linea Diretta 1a, p. 87.

As próximas três atividades são de sistematização tanto de forma quanto de uso e desenvolvem-se através da combinação dos dois tempos do passado, são elas: respostas a perguntas, o ditado e o preenchimento de frases seguindo um modelo préestabelecido.

\section{Quadro 21 - Atividade de pergunta e resposta}

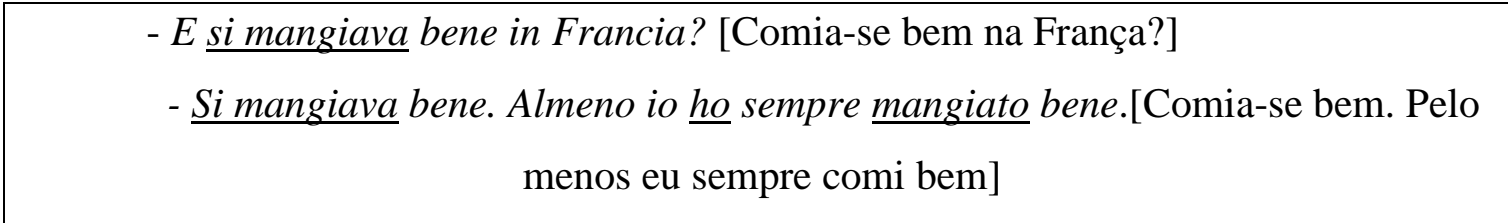

Fonte: Linea Diretta 1a, p. 87.

\section{Quadro 22 - Preenchimento de frases}

Si (andare) andava sempre al mar, una volta (andare) siamo andati in montagna.

Ia-se sempre à praia, uma vez fomos para a montanha.

a. $\mathrm{Si}$ (mangiare) sempre alla mensa, una volta (mangiare) ristorante.

Se (comer) sempre no refeitório, uma vez (comer) restaurante. 
$\mathrm{Na}$ atividade de produção, pede-se ao aluno para pensar nas suas últimas férias e escrever em duas colunas diferentes, já desenhadas no livro, aquilo que eles realizaram apenas uma vez ou que faziam sempre. A partir do preenchimento da tabela, propõe-se uma atividade oral em que um aluno pergunta ao outro o que fez ou o que fazia durante as férias. As respostas inseridas no livro, na coluna 1 ou na coluna 2, já conduzem o aluno para a utilização do imperfetto ou passato prossimo.

A unidade didática seguiu o mesmo percurso da analisada anteriormente sobre o passato prossimo em que, primeiro, são propostas atividades de output controlado e, depois, na chamada fase de verificação, a parte de produção oral e escrita tende a ser mais livre e o aprendiz é levado a utilizar também outras estruturas na produção de um texto coerente e capaz de ser compreendido pelo seu interlocutor. Novamente, podemos reconhecer que a gramática é apresentada explicitamente com vistas a ser aplicada em uma situação comunicativa e que é "treinada" por parte, antes que o aluno seja deixado mais livre na comunicação.

O texto autêntico proposto para leitura foi extraído do livro de uma autora italiana e narra sua transferência de convento fazendo uso de muitos verbos no imperfetto. Além do input oferecido, há um exercício de compreensão de texto que não exige do aluno uma produção elaborada para responder às perguntas, porque é formado apenas por frases que devem ser completadas pelo verbo do texto. A produção oral apoia-se no tema do texto e propõe perguntas concernentes a vida estudantil dos alunos e os seus interesses naquele período as quais devem ser respondidas em grupo, propiciando a interação e estimulando o uso de verbos da marca imperfectiva, visto que esses são encontrados no enunciado do exercício. As atividades seguintes tanto de produção oral ou de preenchimento dos espaços com os verbos no tempo adequado sempre evidenciam a diferença de uso entre os dois tempos estudados na unidade. 
Outros pontos gramaticais abordados na mesma unidade didática são: o gerúndio modal e o uso de "ogni/ognuno/tutti" [cada/cada um/ todos]. Com relação às intenções comunicativas, pretende-se desenvolver as habilidades de se informar sobre algo, concluir um pensamento e exprimir surpresa.

O livro de exercícios apresenta diversas atividades semelhantes àquelas realizadas em classe: preenchimento de textos com passato prossimo o imperfetto, preenchimento de frases com esses mesmos tempos, leitura e uma tabela para conjugação de verbos no tempo imperfetto. Não observamos nesta unidade didática nenhuma tarefa relacionada à produção de tex to livre.

Na tabela gramatical de consulta, além da formação morfológica do imperfetto, segue uma explicação do uso do imperfetto, com exemplos, onde se afirma que tal forma é utilizada para indicar uma ação que se repete no passado e que se usa frequentemente também em verbos que indicam estado de ânimo, como, por exemplo: “essere, sentire, sentirsi, stare” [ser, sentir, sentir-se, estar].

Outro item a ser considerado é uma página explicativa contrapondo os dois tempos do passado, evidenciando através das definições e dos exemplos, o passato prossimo como tempo utilizado para exprimir uma ação concluída, pontual ou para expressar uma sequência de ações. Por outro lado, em contraposição, o imperfetto refere-se a uma ação em desenvolvimento no passado e exprime repetições e ações habituais. A última consideração elaborada pelo livro é importante, pois aborda as diferenças significativas produzidas pelos diferentes tempos do passado no mesmo verbo. Por exemplo: "Ho saputo che sei stato in Francia" [Soube que esteve na França]. O verbo sapere utilizado no passato prossimo transmite o significado de vir a saber. No outro exemplo, "Io ho studiato il francese. Non lo sapevi? [Eu estudei o 
francês. Não sabia?], o mesmo verbo conjugado, porém, no imperfetto, retrata a ideia de estar ciente de algo.

Durante o nível III dos cursos extracurriculares do Italiano no campus em que, conforme já dissemos, é adotado o material Linea diretta 1 b, os aprendizes aprendem algumas especificidades na formação do passato prossimo como, por exemplo, a sua formação com os verbos reflexivos, e a concordância de gênero e número que ocorre com o uso desse tempo junto aos pronomes diretos, além do uso transitivo e intransitivo de alguns verbos. Na parte de exercícios, indicada pelos autores para ser realizada em casa, somente na unidade 3 aparecerá uma atividade de preenchimento de espaços em um texto com os verbos passato prossimo e imperfetto.

Na última página da unidade 4, na leitura, há um texto de uma escritora italiana no qual ela relata uma experiência de viagem na África e utiliza na narração principalmente os dois tempos do passado aprendidos até o momento. O exercício a partir da leitura é completar algumas frases com os verbos do texto e escrever, por meio dos códigos propostos, de que tipo de ação se trata. A sistematização da oposição entre os tempos do passado, nesse caso, parte também de um exercício de preenchimento de espaços, mas aprofunda um pouco mais as diferenças, pois leva o aluno a refletir no sentido que cada ação desempenha dentro do texto e, a partir disso, verificar a qual marca aspectual o verbo foi associado. 


\section{Quadro 23 - Tipos de ação}

Tornando al testo completate le frasi e per ogni frase decidete se si tratta di

1. Un'azione conclusa, 2. Un'azione em corso, 3. Una descrizione, 4. Un'incontro di due azioni, 5. Uno stato d'animo

[Tornando ao texto completem as frases e para cada uma decidam se se trata de

1. Uma ação concluída, 2. Uma ação em curso, 3. Uma descrição, 4. Um encontro de duas ações, 5. Um estado de ânimo

Fonte: Linea diretta 1b, p 55.

Para concluir a unidade, com o objetivo de desenvolver a habilidade oral, é sugerido que o aprendiz conte a um colega se já lhe ocorreu algum problema durante uma viagem e, novamente, não há produção textual que estimule o aprendiz a desenvolver a habilidade de escrever em L2.

No livro de exercícios, também há um texto para ser preenchido com os verbos nos tempos do passado e a gramática de consulta apresenta, mais uma vez, a oposição entre o passato prossimo e o imperfetto, evidenciando com exemplos e definições que o primeiro indica uma ação do passado concluída, enquanto o segundo se usa para descrever uma ação no curso do seu desenvolvimento, para fazer uma descrição, quando se deseja indicar um estado de ânimo ou uma condição física. O livro considera que quando uma ação em curso é interrompida por outra, usa-se o imperfetto para descrever a primeira e o passato prossimo para a segunda.

No nível IV da língua, de acordo com a divisão utilizada nos cursos extracurriculares, os professores abordam as lições 5, 6, 7 e 8. Na quinta unidade, ainda se estuda o passato prossimo, pois ele é empregado também nas construções com os verbos modais e, a partir das outras unidades didáticas, outros tempos e estruturas são abordados como: o condicional e o imperativo, além das intenções comunicativas 
desenvolvidas. O livro de exercícios, por sua vez, também aborda principalmente, as novas estruturas em estudo e os tempos do passado aparecem apenas em algumas frases, não necessariamente, com o foco na sua forma ou uso.

A primeira lição do Linea diretta 2, a partir do diálogo inicial dividido em partes, explora as combinações possíveis entre passato prossimo e imperfetto evidenciando os efeitos produzidos pelo seu uso. São mostradas frases com passato prossimo e imperfetto, indicando uma ação pontual ocorrida durante o acontecimento de outra, passato prossimo e passato prossimo, mostrando a sucessão de acontecimentos, imperfetto e passato prossimo, expressando uma ação que está para acontecer quando ocorre outra e imperfetto e imperfetto, descrevendo situações e pessoas. Essas explicações são seguidas por atividades que exercitam o uso dos tempos com as funções indicadas acima e são semelhantes aos exercícios de sistematização que compunham as outras unidades didáticas cujo foco estava nos tempos do passado, isto é, transformações de frases seguindo um modelo proposto. Observamos que o percurso oferecido nessa unidade também parte do input e visa chegar ao output desde o menos controlado até o mais livre que leve os aprendizes a interagirem numa conversação mais próxima da realidade. 


\section{Quadro 24 - Retomada de tempos verbais}

\section{Tutte a te capitano!}

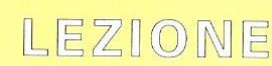

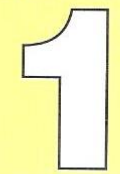

\section{QUESTIONARIO}

Guido racconta una disavventura di qualche giorno prima.

a. Che cosa aveva in tasca Guido quando è entrato dal gioielliere?

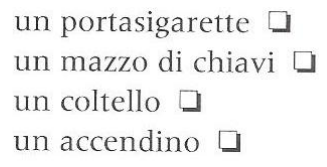

b. Guido dal gioielliere voleva far riparare

l'orologio.

la catenina. $\square$

l'anello.

c. Come ha capito Guido che nel negozio c'era un rivelatore di metalli?

Perché si è accesa una luce.

Perché ha sentito una sirena.

Perché ha sentito suonare una campana.

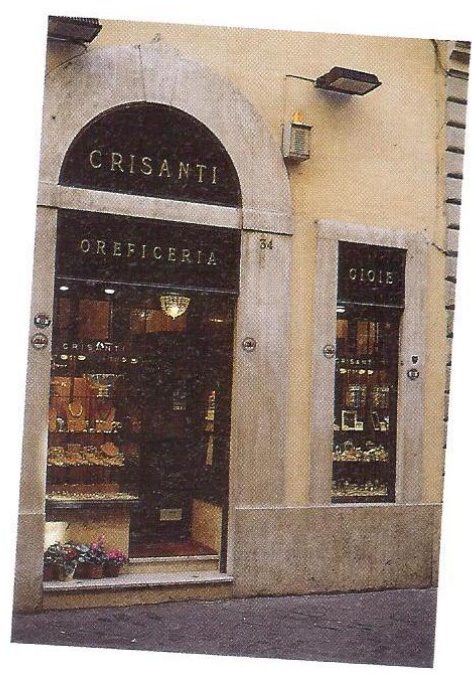

d. Quando Guido ha voluto mostrare quello che aveva in tasca, il gioielliere

ha chiamato la polizia. $\square$

ha preso una pistola.

è scappato.

e. Quando tutto si è chiarito, Guido e il gioielliere sono andati in un per

Fonte: Linea diretta 2, p. 13. 


\section{Quadro 25 - Combinação de passato prossimo e imperfetto}

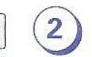

\section{DIALOGO}

- Allora, Guido, com'era quella storia che stavi raccontando ieri?

Quale? Quella del gioielliere?

Sì, perché io me ne sono andata proprio mentre la raccontavi.

- Sì, niente, è successo che la mia catenina, sai, quella che ho sempre al collo ...

Quella con la madonnina?

- Esattamente quella. Si è rotta e allora io sono andato da un gioielliere per farla riparare. E sai com'è adesso? I gioiellieri, come le banche, hanno una doppia porta.

- Certo.

- Allora io ho suonato e il gioielliere m' ha aperto la prima porta. Io sono entrato, la prima porta si è chiusa e io stavo per aprire la seconda porta, quando improvvisamente una campana, un campanello, ha cominciato a suonare.

Io me ne sono andata proprio mentre tu la raccontavi.

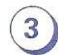

\section{ESERCIZIO}

Ripetete il dialogo secondo il modello.

storia - tu raccontare - del gioielliere - io andarmene

$\square$ Allora, com'era quella storia che stavi raccontando?

$\circ$ Quale? Quella del gioielliere?

$\square$ Sì, io me ne sono andata proprio mentre tu la raccontavi.

a. trasmissione radiofonica - tu ascoltare - sui giovani - io andarmene

b. documentario - voi guardare - sulla Sardegna - noi uscire

c. dolce - Maria e Giulia preparare - con le noci - noi andarcene

d. programma - tu guardare - su Telemontecarlo - io andare via

e. barzelletta - Sandra raccontare - dei due carabinieri - io rispondere al telefono

Fonte: Linea diretta 2, p. 14.

Para finalizar a unidade didática, o livro apresenta um teste em que se deve completar os espaços de um texto com os verbos do passado. Esse tipo de atividade também é encontrado em grande quantidade na primeira lição do livro de exercícios. As explicações sobre tais tempos são retomadas na gramática para consulta, outra vez, como vimos anteriormente, com definições e exemplos, mostra-se também o uso dos tempos do passado na narração, indicando contemporaneidade de acontecimentos, eventos em sucessão ou interrupções de ação em curso. Para finalizar as explicações, os 
verbos potere, volere e dovere [poder, querer, dever] são exemplificados indicando as diferenças de efeitos produzidas se utilizados com o tempo perfectivo ou imperfectivo.

As unidades didáticas sucessivas abordam outras estruturas morfossintáticas como o futuro ou os pronomes relativos, além de funções comunicativas como pedir ou dar conselhos, indicar soluções sob condições, fazer pedidos e promessas, dar permissões, etc.

Em suma, com relação às tipologias de atividades, estão presentes no livro didático vários exercícios gramaticais e estruturais, atividades comunicativas e de compreensão de texto, mas nesse grupo, apesar de constatarmos a presença de role play e atividade de preenchimento de espaços, não comparecem tarefas colaborativas que se concentrem na produção escrita por meio das quais poderiam ser alcançados, de forma mais efetiva, os efeitos do output, especialmente, o efeito reflexivo e o metalinguístico, que, de modo especial, favorecem a aquisição/aprendizagem da L2. 


\section{O passato prossimo e o imperfetto nas produções dos aprendizes}

\subsection{O teste}

A partir da composição escrita e da atividade guiada realizada por aprendizes brasileiros em contexto de instrução formal nos cursos extracurriculares de Italiano, analisamos as utilizações dos tempos verbais ditos do passado passato prossimo e imperfetto procurando observar como se dá a sua escolha e associá-la a sua telicidade ou não telicidade e ainda observar a ocorrência ou não desses tempos nas produções antes do aprendizado explícito, depois desse aprendizado e com um distanciamento do mesmo. Para tanto, os aprendizes foram submetidos a dois tipos de teste: a produção de texto e o cloze.

Após a realização de ambas as atividades, passemos à análise. Nas composições verificamos como foi realizada a escolha dos tempos verbais dos verbos sugeridos no quadro. Verificamos se os alunos usaram aqueles verbos, quantas vezes os utilizaram e em qual tempo verbal o conjugaram. A partir desses dados somados e divididos pelo número de alunos que participaram do teste, obtivemos a média de uso do verbo nos tempos presente, passato prossimo e imperfetto por aluno e demonstramos em gráficos para que pudéssemos analisar os resultados encontrados. Em cada gráfico consideramos o desvio padrão, uma medida usada para calcular a "variabilidade dos dados em torno de uma distribuição de frequências" ${ }^{35}$, dessa forma através dessa ferramenta, medimos a dispersão dos valores para mais ou para menos em torno da média. Tal cálculo buscou

\footnotetext{
${ }^{35}$ http://www.inf.furb.br/sias/saude/Textos/desvio_padrao.htm, acesso em 22/12/2011.
} 
garantir que os resultados utilizados na análise fossem o mais próximo possível do uso do aluno.

O nosso objetivo, conforme já observamos, foi verificar se podemos associar as escolhas dos tempos verbais às teorias de telicidade descritas nos trabalhos de Andersen e Shirai (1996), verificando também se o passato prossimo e imperfetto são usados para diferenciar aspectualmente as ações descritas. Nas produções dos alunos não consideramos se a morfologia do verbo não correspondia perfeitamente às normas da língua italiana, pois esse não era o nosso objetivo. Consideramos apenas que o tempo verbal fosse reconhecível. Dessa forma, em alguns textos, mesmo com o verbo auxiliar não tendo sido escolhido adequadamente, ou com a conjugação do verbo não concordando com o sujeito, os verbos entraram na análise porque foi possível reconhecer o tempo verbal utilizado.

Outro objetivo que buscamos atingir foi o de compreender se ocorre o uso dos tempos verbais ditos do passado, passato prossimo e imperfetto, nas produções textuais em seguida ao aprendizado explícito ou se a ocorrência deles se dá posteriormente ao aprendizado. Por meio da aplicação do teste em alunos que não haviam estudado explicitamente o imperfetto, tentamos também perceber se, por se tratar de um tempo semelhante em uso ao imperfeito do português brasileiro, o aprendiz já o utiliza em suas produções.

Os testes foram aplicados aos alunos no segundo semestre de estudo da língua italiana (após aproximadamente sessenta horas de curso presencial). Para a realização da atividade da pesquisa, escolhemos o momento em que eles haviam acabado de estudar explicitamente o passato prossimo, sem ainda ter recebido instruções explícitas relativas ao imperfetto. Os mesmos testes foram aplicados a alunos do terceiro semestre (após aproximadamente cento e quinze horas de estudo da língua italiana) no momento em 
que já haviam estudado as duas estruturas explicitamente e logo após terem estudado o imperfetto.

A tarefa que utilizamos para o teste também foi aplicada aos mesmos alunos nos dois semestres seguintes (depois de um semestre e depois de um ano), porque nosso objetivo era verificar quais efeitos são provocados pelo maior grau de instrução formal, pela maior quantidade de horas de exposição ao input e de contato com a língua e pelo distanciamento temporal da instrução explícita relativa aos tempos em questão. Ou seja, se nos primeiros estágios do aprendizado, o aprendiz ligava a escolha do tempo verbal à telicidade do verbo, isso permanece nos estágios mais avançados ou essa escolha se dá pela função e efeito que quer imprimir ao discurso?

Dessa maneira, a mesma atividade foi realizada três vezes. Optamos por aplicar sempre o mesmo tipo de teste para que obtivéssemos dados que pudessem ser comparados. As atividades foram realizadas em maio de 2010 nos níveis II e III dos cursos do Italiano no campus. Os aprendizes do nível II já haviam estudado o passato prossimo, mas ainda não o imperfetto, por outro lado, o nível III, já havia recebido instruções explícitas sobre os dois tempos verbais. No semestre seguinte aplicou-se o teste, em novembro de 2010, nos grupos de língua III e IV que também já haviam aprendido os dois tempos verbais. Por fim, em junho de 2011, foram aplicados os testes nos alunos dos níveis IV e $\mathrm{V}$, que já haviam recebido instruções explícitas sobre ambos os tempos do passado. Em especial, o grupo de alunos do nível V já havia estudado também a unidade 1 do Linea Diretta 2, na qual são abordadas novamente as diferenças aspectuais entre os dois tempos. Tais níveis foram escolhidos para que pudéssemos obter um número representativo de alunos e, ainda, observar o desenvolvimento dos grupos durante o maior tempo possível. 
Embora os alunos não fizessem parte do mesmo grupo de alunos que frequentavam as aulas com o mesmo professor, já que os testes foram aplicados em diversos horários e, portanto, em vários grupos de nível II, vários grupos de nível III etc., no momento de contagem de verbos e análise de dados, todos os níveis II formam um único grupo, assim como os níveis III, os níveis IV e o nível $\mathrm{V}$, ainda que tenham entrado na pesquisa o grupo do III do primeiro semestre de 2010 e o grupo III do segundo semestre de 2010, ou seja, eles fizeram o teste em momentos diferentes, mas o nível linguístico, segundo a divisão proposta pelo Italiano no Campus, era o mesmo.

Devido à dinâmica dos cursos extracurriculares, os alunos que participaram da primeira pesquisa não foram necessariamente os mesmos que a concluíram, já que alguns abandonaram o curso, não estavam presentes no dia da realização da atividade ou, ainda, matricularam-se no curso após a aplicação de uma das atividades.

Através da seguinte tabela, podemos observar o número de alunos participantes: 
Tabela 2 - Aplicação dos testes

\begin{tabular}{|c|c|c|c|c|}
\hline LIVRO & $\begin{array}{c}\text { Linea Diretta } \\
\text { nиоvо } 1 \mathrm{~A}\end{array}$ & $\begin{array}{c}\text { Linea Diretta } \\
\text { nuovo } 1 B\end{array}$ & $\begin{array}{c}\text { Linea Diretta } \\
\text { nuovo } 1 B\end{array}$ & Linea Diretta 2 \\
\hline Nível & Nível II & Nível III & Nível IV & Nível V \\
\hline $\begin{array}{l}\text { Aplicação das } \\
\text { atividades }\end{array}$ & Maio 2010 & Maio 2010 & Novembro 2010 & Junho 2011 \\
\hline Participantes & 36 alunos & 26 alunos & $\begin{array}{l}20 \text { alunos } \\
16 \text { alunos } \\
\text { participaram do } \\
\text { primeiro teste }\end{array}$ & $\begin{array}{c}23 \text { alunos } \\
15 \text { alunos } \\
\text { participaram de } \\
\text { todos os testes; } 2 \\
\text { participaram do } \\
\text { segundo e } \\
\text { terceiro testes; } 1 \\
\text { participou do } \\
\text { primeiro e } \\
\text { terceiro testes e } \\
5 \text { apenas do } \\
\text { último teste }\end{array}$ \\
\hline $\begin{array}{l}\text { Horas } \\
\text { aproximadas de } \\
\text { curso }\end{array}$ & $60 \mathrm{~h}$ & $115 \mathrm{~h}$ & $165 \mathrm{~h}$ & $200 \mathrm{~h}$ \\
\hline $\begin{array}{ll}\text { Aplicação } & \text { das } \\
\text { atividades } & \end{array}$ & & $\begin{array}{c}\text { Novembro } 2010 \\
21 \text { alunos } \\
17 \text { alunos } \\
\text { participaram } \\
\text { também do } \\
\text { primeiro teste }\end{array}$ & $\begin{array}{c}\text { Junho } 2011 \\
\\
16 \text { alunos } \\
10 \text { alunos } \\
\text { participaram de } \\
\text { todos os testes; } \\
4 \text { alunos apenas } \\
\text { do primeiro e } \\
\text { terceiro testes; } \\
\text { dois apenas do } \\
\text { último }\end{array}$ & \\
\hline
\end{tabular}




\subsubsection{A produção escrita}

A primeira parte da atividade consistiu na projeção e sucessiva produção escrita de um trecho de um filme, Io non ho paura de Gabriele Salvatores (2003). A cena mostrada no filme se passa no verão de 1978, quando as crianças de uma pequena cidade do Sul da Itália estavam de férias. Durante um dos passeios, Michele, um garoto de 9 anos, descobre que os adultos da cidade haviam sequestrado uma criança e a haviam escondido em um buraco cavado na terra perto de uma casa abandonada. Michele procura entender a situação e, aos poucos, percebe que seus pais tinham participado do sequestro. A cena escolhida dura seis minutos e meio (de 14'30 ao 21') e mostra o garoto que, já sabendo que havia alguém escondido, corre até o esconderijo e começa a jogar pedras no buraco para ver se alguém aparece. De repente, o garoto sequestrado apareceu e Michele, amedrontado, corre de volta para casa. Ao chegar ao seu bairro, o pai briga com o garoto, pois ele havia saído sem avisar deixando-o preocupado.

Na aplicação da atividade, explicamos aos aprendizes que aquela era uma atividade de pesquisa cujo objetivo era o estudo do sistema dos tempos verbais da língua italiana. Dessa maneira, pedimos que respondessem a um questionário (vide anexo) que definiria o público pesquisado. Em seguida, lemos com os alunos a sinopse do filme para que lhes fosse dado o contexto. Explicamos-lhes que havia dois quadros no texto em que eram propostos verbos que poderiam ser utilizados e também outro com substantivos que os ajudariam na construção do texto. Propusemos aos alunos que iniciassem o texto para descrever a cena da seguinte forma "Era estate. Faceva molto caldo. Michele andava in bicicletta quando..." [Era verão. Fazia muito calor. Michele 
andava de bicicleta quando]. Os alunos não foram direcionados explicitamente a usarem um tempo verbal específico. Alguns perguntaram em qual tempo deveriam fazer a descrição, mas a resposta fornecida era a de que deveriam continuar o enunciado escolhendo o tempo que melhor se encaixasse no texto. A escolha da cena se deu porque acreditamos que pudesse favorecer o uso dos dois tempos verbais que estamos examinando, pois, é composta por uma situação que representa continuidade e contém ações que estão se desenvolvendo no passado e são interrompidas por ações pontuais. Esse tipo de cena deveria estimular nos aprendizes o uso de imperfetto e passato prossimo. Propusemos no início do texto o uso de verbos no imperfetto porque pensamos que estimularia os alunos a usarem as formas verbais em estudo. Se não houvéssemos optado por esse início, os alunos estariam livres para escolher tanto tempos do passado quanto do presente como ponto de partida. Acreditamos que o estabelecimento de um ponto de referência no passado orientaria os aprendizes.

Os seis minutos e meio da cena do filme foram divididos em duas partes. Assim, os alunos assistiram duas vezes a primeira metade e depois a narraram. Em seguida, viram duas vezes a segunda metade e também a descreveram. Como o léxico não é o foco do nosso trabalho, fornecemos alguns lexemas para ajudar os alunos na produção do texto. $\mathrm{O}$ fato de termos indicado alguns verbos tinha, além disso, o objetivo de estimular o uso de verbos parecidos, o que poderia nos ajudar na hora de avaliar as produções.

Fornecemos os seguintes verbos: vedere, guardare, camminare, sentire, scoprire, cercare, esserci, lanciare, continuare, trovare, comparire, cadere, pedalare, aprire, arrivare [ver, olhar, caminhar, ouvir, descobrir, procurar, haver, jogar, continuar, aparecer, cair, pedalar, abrir, chegar]. O verbo essere [ser], por ter aparecido com muita frequência nas produções dos alunos também foi considerado na pesquisa. 
Durante a análise, porém, não incluímos todos os verbos, mas os escolhemos levando em consideração dois critérios, dos que apresentavam traços semelhantes dinamicidade, duração e telicidade - utilizando alguns exemplos de cada grupo e, ainda, a frequência com que os aprendizes os usaram. Dessa forma, por exemplo, o verbo comparire foi retirado da pesquisa já que houve apenas uma ocorrência.

Foram considerados para análise final os seguintes verbos:
a) Vedere: + duração, + dinamicidade, - telicidade;
b) Pedalare: + duração, + dinamicidade, - telicidade;
c) Camminare: + duração, + dinamicidade, - telicidade;
d) Esserci: + duração, - dinamicidade, - telicidade;
e) Continuare: + duração, - dinamicidade, - telicidade;
f) Essere: + duração, - dinamicidade, - telicidade;
g) Cadere: - duração, + dinamicidade, + telicidade;
h) Aprire: + duração, + dinamicidade, + telicidade;
i) Lanciare: + duração, + dinamicidade, + telicidade;
j) Scoprire: - duração, + dinamicidade, + telicidade;
k) Arrivare: - duração, + dinamicidade, + telicidade;
1) Trovare: - duração, + dinamicidade, + telicidade; 


\subsubsection{O cloze}

A segunda parte da atividade consistiu em preencher as lacunas de um texto. $\mathrm{O}$ texto, encontrado na internet, foi escolhido por ser uma produção escrita espontaneamente por um italiano, ou seja, não era um texto adaptado para atingir a determinados objetivos, e por se basear em um assunto comum entre os alunos, abordado inclusive no livro didático adotado pelo curso: uma viagem realizada, o que sugeria o uso do passato prossimo e do imperfetto. O texto narra a viagem de uma italiana ao Brasil e, por ser longo, algumas partes foram retiradas. As lacunas deveriam ser preenchidas com verbos indicados entre parênteses e a escolha do tempo verbal coube aos alunos, apesar de o texto conter palavras que deveriam estimular os aprendizes a usar passato prossimo e imperfetto, como Nell'estate del 2004 [No verão de 2004] ou mentre [enquanto]. Para essa segunda atividade, a única instrução dada foi a de que deveriam completar os espaços do texto utilizando-se dos verbos entre parênteses nos tempos que considerassem adequados.

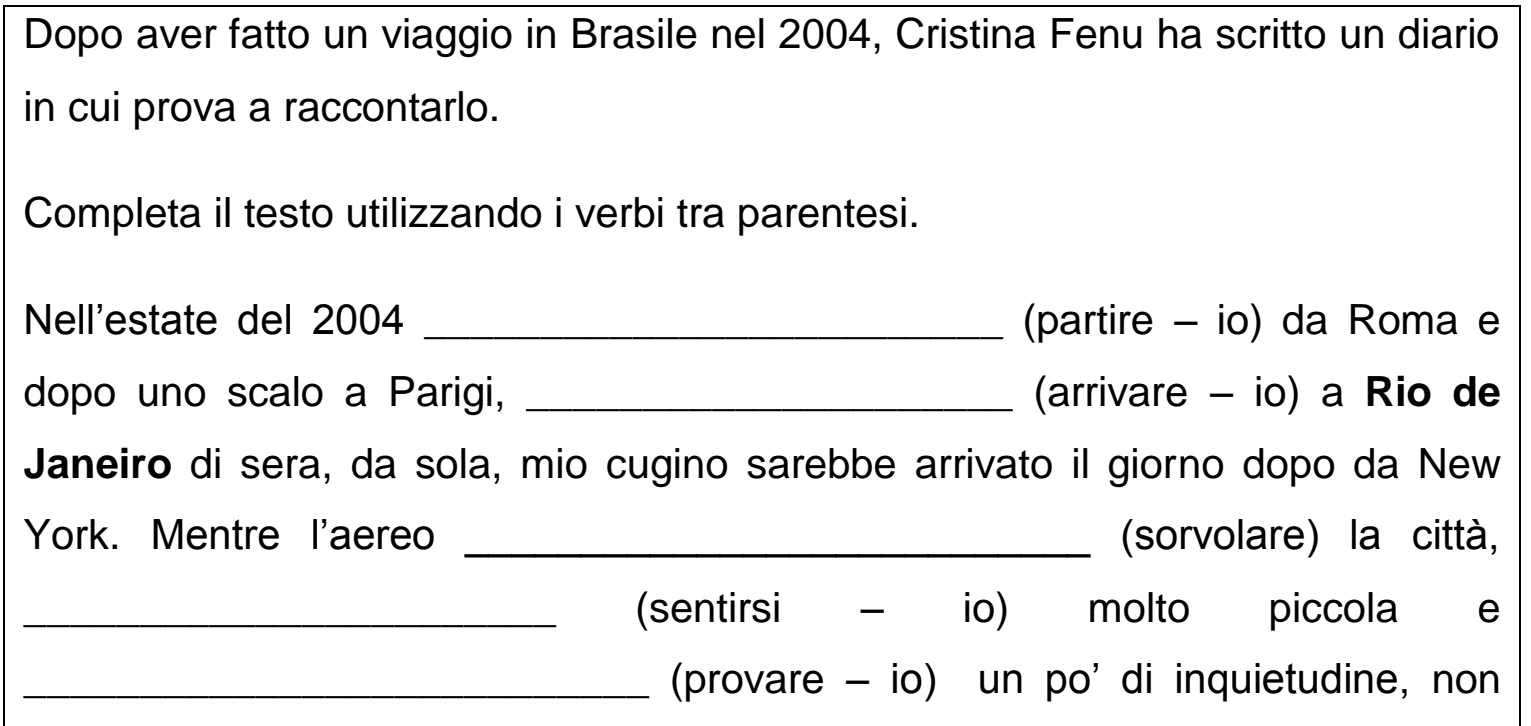


(riuscire - io) a vedere la fine delle migliaia di luci della città...

In molti mi avevano spaventato sulla pericolosità di questo viaggio e sui rischi che avrei corso arrivando in una metropoli del genere per la prima volta da sola e senza conoscere la lingua. (prendere - io) un taxi e subito (mettermi - io) a parlare con il conducente, un uomo di mezza età, molto simpatico, io (parlare) in spagnolo e lui in portoghese $\mathrm{e}$ (capirsi - noi), non so come...

Avevo prenotato un ostello a Copacabana e (esserci) un piccolo imprevisto... (esserci) una festa in piazza proprio davanti l'ostello, ottimo benvenuto. (trovare - io) la città sensazionale, (visitare - noi) il Pao Azucar, il Cristo Redentor,

Copacabana, Ipanema, il quartiere di Santa Teresa, questi sono stati i primi 2 giorni.

La vita notturna a Copacabana (essere) un po' dispersiva. (...)

La seconda serata (preferire - noi) restare in piazza dato che la festa (durare) 3 giorni !

\subsection{Os participantes}

A primeira folha da aplicação dos testes é composta por um questionário que busca definir o perfil do público que estuda a língua italiana nos cursos extracurriculares organizados pela Área de Língua e Literatura Italiana do Departamento de Letras Modernas, FFLCH - USP e, em especial, procura entender que tipo de alunos participaram da pesquisa. 


\section{\begin{tabular}{lllllll}
\hline PARA A & PESQUISA & PRECISAMOS & DE & ALGUNS & DADOS...
\end{tabular} AGRADECEMOS SUA COLABORAÇÃO!}

Idade: Profissão:

Grau de escolaridade:

Idiomas que fala:

Há quanto tempo estuda Italiano no Italiano no Campus:

Já estudou Italiano em outra época e parou? Se sim, quando e onde? Por quanto tempo?

É de origem italiana?

Já foi para a Itália? Se sim, quando e por quanto tempo ficou?

Por que estuda a língua?

Tem contato com a língua fora do período de aula? Se sim, onde?

Lê jornais, livros, escuta músicas fora do período de aula? 
A partir das perguntas que foram respondidas (anexo ) em português, chegamos à conclusão de que apesar de a maioria dos estudantes possuírem a idade entre 50 a 59 anos, os alunos que participaram dos testes têm no mínimo 20 e alguns mais de 60 anos. Os alunos são brasileiros, graduados e exercem profissões variadas, apesar de grande parte dos grupos ser de profissionais aposentados. No geral, os aprendizes já falam outra língua estrangeira, o inglês ou o espanhol, e estudam a língua italiana há dois ou três semestres por prazer. A maioria não havia estudado anteriormente, não havia visitado a Itália, apesar de ser descendente de italianos. Outro grande grupo é aquele que não tem contato com a língua fora do horário de aula, entretanto, realiza leituras na língua estrangeira. Esses dados podem ser observados nos seguintes gráficos:

\section{Gráfico 1 - Idade dos participantes}

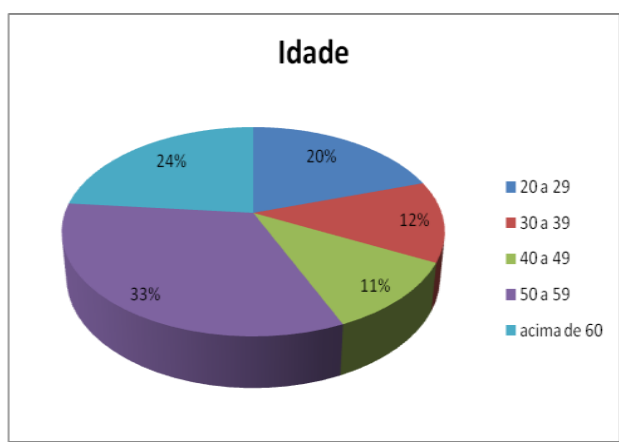

\section{Gráfico 3 - Escolaridade dos alunos}

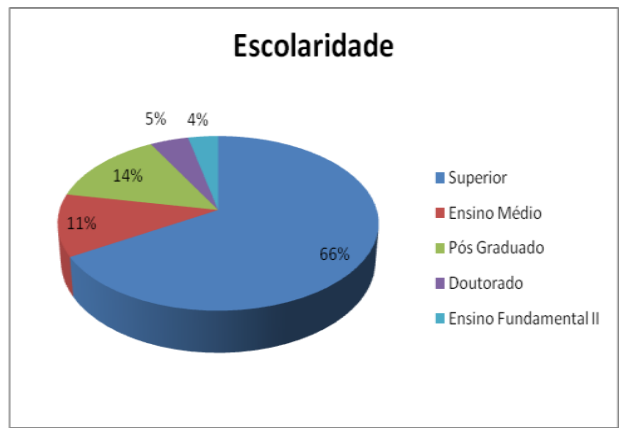

Gráfico 2 - Profissão dos alunos

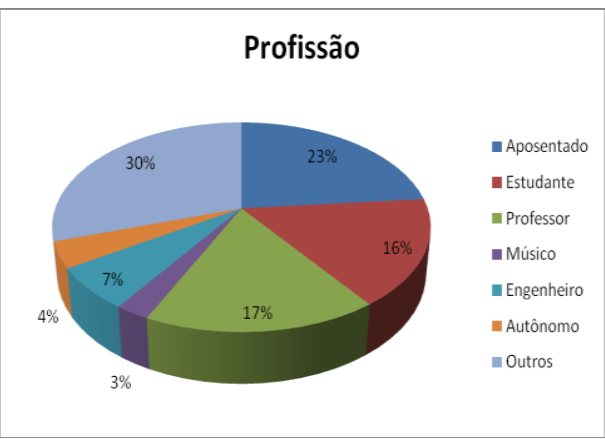

Gráfico 4 - Idiomas falados

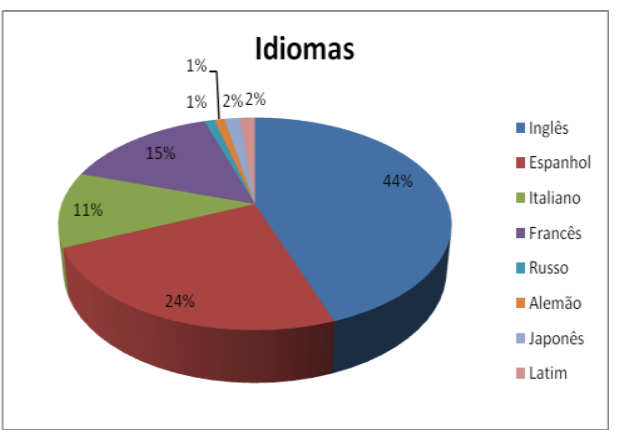


Gráfico 5 - Tempo de estudo

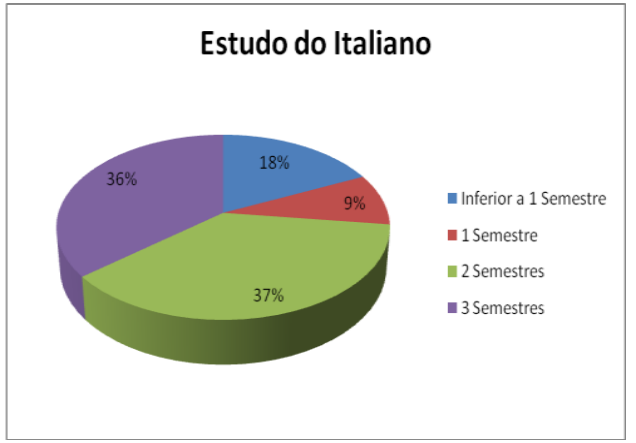

Gráfico 7 - Origem italiana

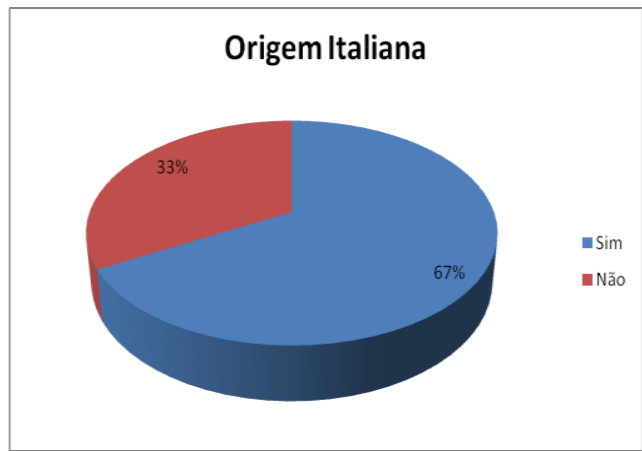

Gráfico 9 - Motivo de estudo

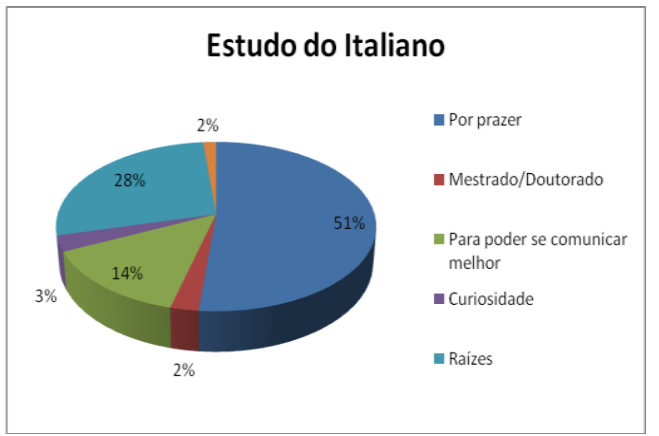

Gráfico 6 - Estudo da língua

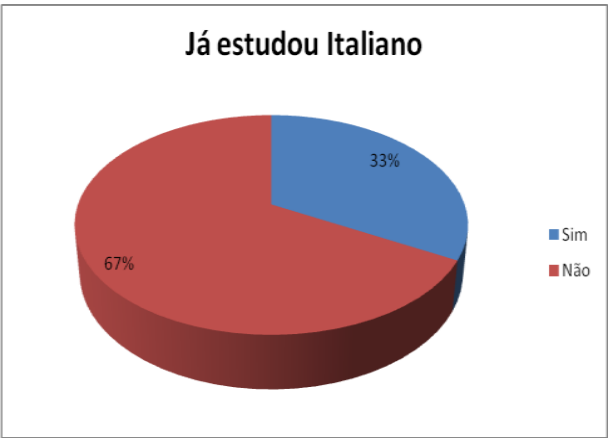

Gráfico 8 - Viagem à Itália

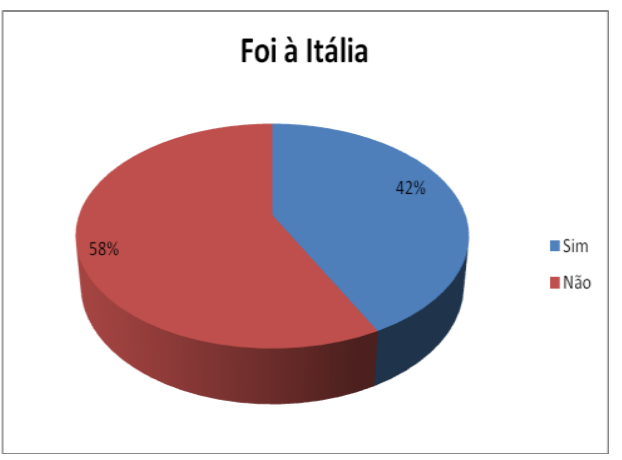

Gráfico 10 - Contato com a língua

Contato com a língua fora da aula

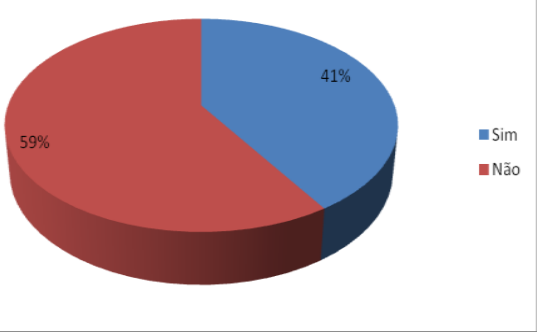

Gráfico 11 - Leitura em língua italiana

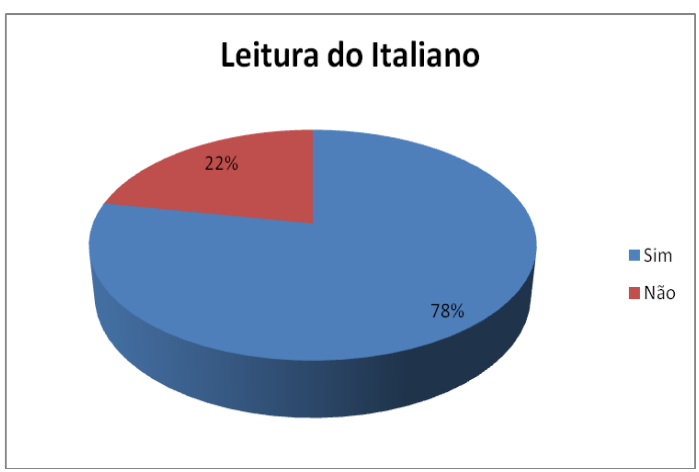


4.3 Tabulação e análise dos dados da produção escrita

GRÁFICOS 1ª ATIVIDADE DA PESQUISA

Gráfico 12 - Verbo vedere

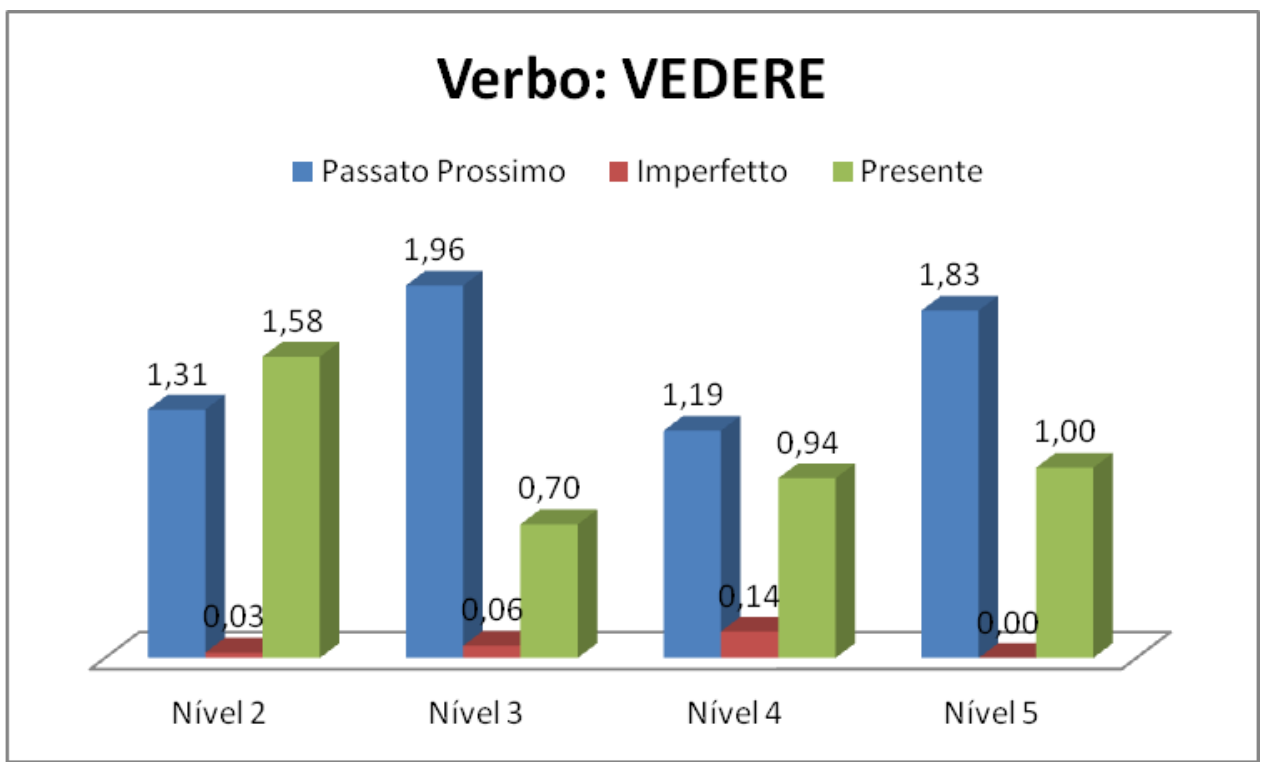

Tabela 3 - Desvio padrão do verbo vedere

\begin{tabular}{|c|c|c|c|c|c|c|c|c|c|c|c|}
\hline \multicolumn{12}{|c|}{ DESVIO PADRÃO } \\
\hline \multicolumn{3}{|c|}{ Nível 2} & \multicolumn{3}{|c|}{ Nível 3} & \multicolumn{3}{|c|}{ Nível 4} & \multicolumn{3}{|c|}{ Nível 5} \\
\hline P.P. & IMP. & PRES. & P.P. & IMP. & PRES. & P.P. & IMP. & PRES. & P.P. & IMP. & PRES. \\
\hline 1,47 & 0,16 & 1,82 & 1,71 & 0,48 & 1,39 & 1,52 & 0,54 & 1,26 & 1,72 & 0 & 1,75 \\
\hline
\end{tabular}

O verbo vedere [ver], caracterizado pelos traços de + duração, + dinamicidade e - telicidade, foi utilizado, no segundo nível, como podemos observar nos gráficos acima, principalmente, no tempo presente. Houve uma grande diferença no nível III em que a maior parte do uso dos verbos por aluno, em vez de ter ocorrido no tempo presente, foi usado nas produções no passato prossimo. É interessante perceber que o uso desse tempo verbal em relação ao presente, não se distanciou tanto um do outro no nível IV, porém, no nível $\mathrm{V}$, ou seja, no último teste a que foram submetidos, a diferença foi mais significativa, já que a recorrência do verbo no passato prossimo é de 1,83 por aluno, enquanto no presente é de 1 por aluno. Notamos nos gráficos que o uso do passado foi marcado por uma oscilação, pois cresceu no nível III, diminuiu no nível IV, todavia, aumentou no nível V. Ainda que a produção textual começasse com um 
verbo no tempo passado, elemento que estimularia a continuação do texto também no passado, houve grande ocorrência dos verbos no presente e, através dos gráficos, percebemos que se no nível II o seu uso superou o passato prossimo, no nível III, a sua utilização diminuiu, porém foi crescente nos próximos dois níveis, ainda que não tenha ultrapassado o uso do passado. O verbo no imperfetto, por sua vez, foi pouco utilizado.

É interessante considerar que o verbo vedere foi utilizado, muitas vezes, em seguida ao início do texto por nós proposto, e a partir desse uso no passato prossimo, há muitas ocorrências de outros verbos no presente, como podemos observar em alguns exemplos:

"Michele andava in bicicletta quando ha visto una serpente osservou, ma continua a pedalare doppo vista una casa la campagna e cammina (... )vedi alcuni maiali, (...), suo padre lo vede" [Michele andava de bicicleta quando viu uma cobra, observou, mas continua a pedalar, depois de ver uma casa no campo e caminha (...) vê alguns porcos (...) seu pai o vê]. $.^{36}-$ Nível II.

"Michele andava in bicicletta quando ha visto un portone nella strada! Curioso ha lasciatto la bicicletta e ha caminato l'aria cercata. Michele encontra lì un pozzo chiuso. Quando aperto Michele ha visto un bambino porco e fino. $\underline{\text { Corre } e ~} \underline{\text { comincia a }}$ pedalare" [Michele andava de bicicleta quando viu um portão na estrada! Curioso deixou a bicicleta e caminhou pela área cercada. Michele encontra ali um poço fechado. Quando aberto Michele viu um menino porco e magro. Corre e começa a pedalar]. Nível II.

No próximo excerto, cabe evidenciar o uso de um verbo que indica uma ação iniciada no passado, entretanto, a ocorrência se dá com um verbo no presente.

\footnotetext{
${ }^{36} \mathrm{Na}$ tradução das produções realizadas pelos alunos, foi mantido o sentido da mensagem que pretendiam transmitir, ainda que houvesse inadequações na linguagem.
} 
"Michele andava in bicicletta quando si è spaventato per una serpente morta nella strada. In questo momento vede una casa abbandonata e pedala tra il portone. Continua per il filo spinato tra il pozzo della casa (...) quando continua aprendo il pozzo e num instante vede un bambino magro, porco, capelo lunghi e occhi che non vedeva luci tra molto tempo". [Michele andava de bicicleta quando se assustou com uma cobra morta na estrada. Nesse momento vê uma casa abandonada e pedala até o portão. Continua pelo arame farpado até o poço da casa (...) quando continua abrindo o poço e em um instante vê um menino magro, porco, cabelos longos e olhos que não viam luzes há muito tempo]. - Nível III.

A tentativa de contrastar duas ações marcando aspectos diferentes ocorre, sobretudo, nos níveis II e III, ainda que sejam poucas as ocorrências.

\section{Gráfico 13 - Verbo camminare}

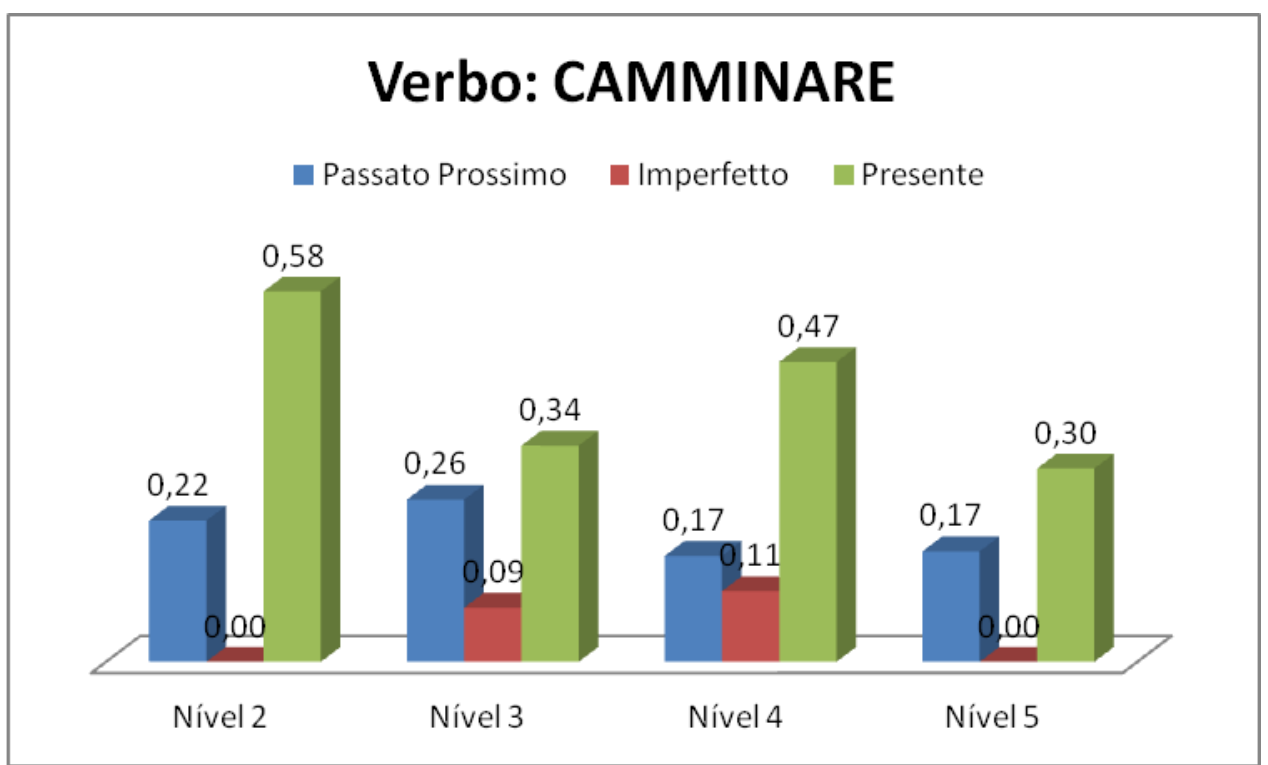

Tabela 4 - Desvio padrão do verbo camminare

\begin{tabular}{|c|c|c|c|c|c|c|c|c|c|c|c|}
\hline \multicolumn{12}{|c|}{ DESVIO PADRÃO } \\
\hline \multicolumn{3}{|c|}{ Nível 2} & \multicolumn{3}{|c|}{ Nível 3} & \multicolumn{3}{|c|}{ Nível 4} & \multicolumn{3}{|c|}{ Nível 5} \\
\hline P.P. & IMP. & PRES. & P.P. & IMP. & PRES. & P.P. & IMP. & PRES. & P.P. & IMP. & PRES. \\
\hline 0,41 & 0 & 0,84 & 0,48 & 0,28 & 0,66 & 0,44 & 0,31 & 0,65 & 0,38 & 0 & 0,70 \\
\hline
\end{tabular}


O verbo camminare [caminhar] apresenta os seguintes traços: + duração, + dinamicidade, - telicidade. O seu uso ocorreu, sobretudo, no tempo presente, independente do nível que o aluno cursava, entretanto, ainda que se sobreponha aos outros, o uso é semelhante ao que ocorreu com o verbo vedere, pois podemos observar que a sua utilização por aluno foi alta no nível II $(0,58)$, diminuiu no nível III $(0,34)$, e aumentou no nível IV $(0,47)$; a diferença, entretanto, é a diminuição no nível V $(0,30)$. O uso do passato prossimo cresceu no nível III, mas diminuiu e se manteve nos próximos dois níveis. Semelhante ao outro verbo, o uso do imperfetto ocorreu nos níveis II e III com um pequeno aumento entre um e outro.

Observemos dois exemplos da ocorrência do verbo no presente. O primeiro excerto nos mostra a descrição realizada no tempo presente, entretanto, no segundo texto, encontram-se os verbos no passato prossimo e a mudança para o presente ocorre justamente com verbo camminare.

"Michele andava in bicicletta quando ve una casa abbandonata. Lui camina verso da casa e scopre un pozzo". [Michele andava de bicicleta quando vê uma casa vê uma casa abandonada. Ele caminha em direção a casa e descobre um poço]. - Nível II.

“... Sentiva paura e ha pedalato più forte. Ha caduto mezzo al campo tra le formiche. Michele ha ritornato al villaggio. Camina frente i maiali, mentre tenta capire lo che $\underline{\text { ha }}$ passato. Suo padre che lo cercava sta arrabbiato" [Sentia medo e pedalou mais forte. Caiu no meio do campo entre as formigas. Michele retornou à vila. Caminha em frente aos porcos, enquanto tenta entender o que passou. Seu pai que o procurava estava nervoso] - Nível III.

A utilização do verbo no próximo excerto também ocorreu no presente, porém, em seguida, a narração foi transformada para o passado. 
"Pedala in quella direccione. Laccia la bicicletta e camina verso a casa che le sembra abandonata. All'arrivare frente a lei, ha risolto da vedere cosa aveva nel pozzo. Il suo occhi non credeva in quello che vedeva. Uno bambino come lui stava preso come un animale. $\underline{\text { Ha sentito }}$ paura..." [Pedala naquela direção. Deixa a bicicleta e caminha em direção a casa que lhe parece abandonada. Ao chegar em frente a ela, decidiu ver o que tinha no poço. O seu olho não acreditava naquilo que via. Um menino como ele estava preso como um animal. Sentiu medo] - Nível IV.

\section{Gráfico 14 - Verbo pedalare}

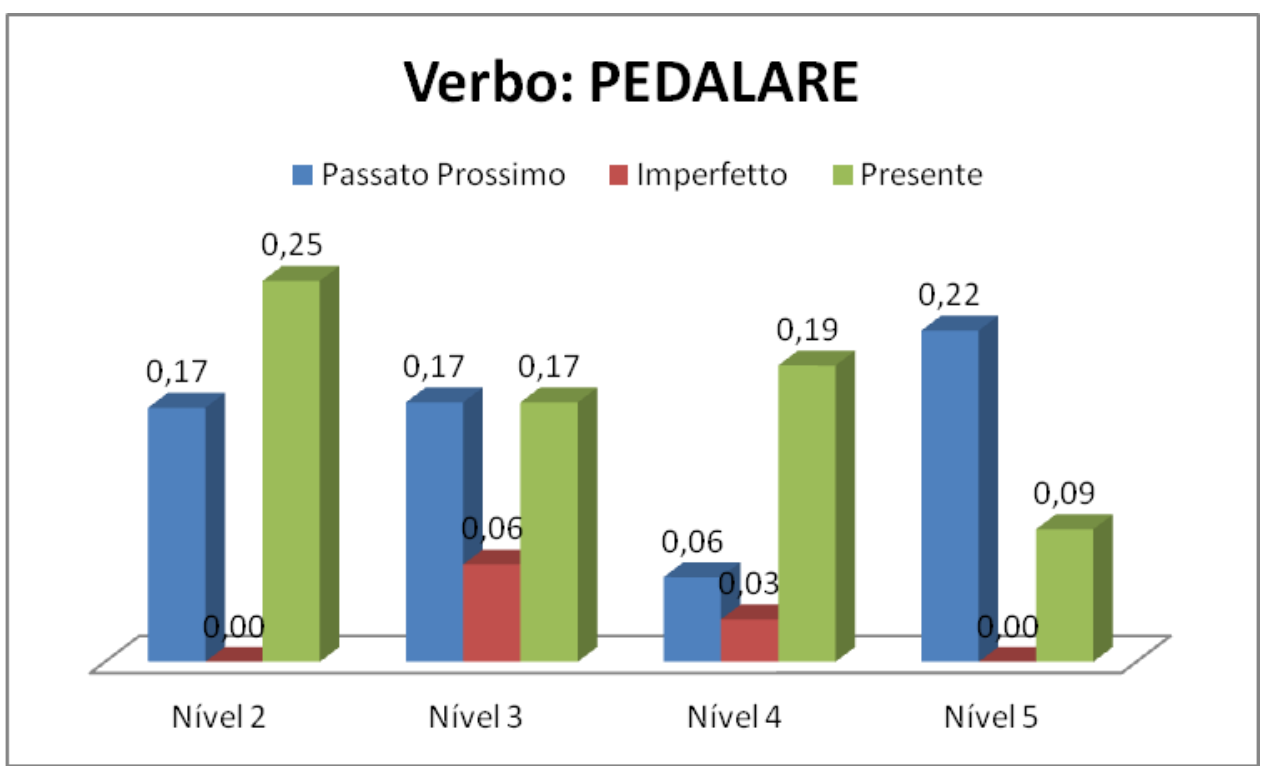

Tabela 5 - Desvio padrão do verbo pedalare

\begin{tabular}{|c|c|c|c|c|c|c|c|c|c|c|c|}
\hline \multicolumn{12}{|c|}{ DESVIO PADRÃO } \\
\hline \multicolumn{3}{|c|}{ Nível 2} & \multicolumn{3}{|c|}{ Nível 3} & \multicolumn{3}{|c|}{ Nível 4} & \multicolumn{3}{|c|}{ Nível 5} \\
\hline P.P. & IMP. & PRES. & P.P. & IMP. & PRES. & P.P. & IMP. & PRES. & P.P. & IMP. & PRES. \\
\hline 0,44 & 0 & 0,55 & 0,43 & 0,24 & 0,43 & 0,23 & 0,16 & 0,40 & 0,51 & 0 & 0,28 \\
\hline
\end{tabular}

A maior parte das ocorrências do verbo pedalare [pedalar], caracterizado pelos traços de + duração, + dinamicidade, - telicidade, foi no tempo presente nos níveis II, apesar da pouca diferença em relação ao seu uso no tempo passato prossimo. No nível seguinte, os usos desses verbos foram semelhantes tanto no presente quanto no passato 
prossimo, ambos atingindo o uso de 0,17 por aluno. No nível IV, porém, o uso do presente supera consideravelmente o uso do passato prossimo e ocorre o inverso no nível V.

Dessa maneira, o fato que observamos nos gráficos do verbo camminare, também ocorre com o verbo pedalare, ou seja, o uso do presente diminuiu em relação ao nível II, aumentou em relação ao nível III e diminuiu em relação ao nível IV. O uso do passato prossimo, por sua vez, permaneceu igual nos dois primeiros níveis de análise, considerando que o desvio padrão desses usos é semelhante, diminuiu no nível IV e aumentou no nível V. Houve ainda poucas ocorrências desse verbo no imperfetto, mas elas se deram nos dois níveis intermediários da pesquisa, isto é, III e IV, semelhante ao verbo camminare.

Podemos observar um exemplo do uso desse verbo:

“...lui è andato per un piccolo camino ancora senza sua bicicletta, alla fine del campo il ragazzo scopre un buco in quale ha visto un ragazzo più bianco, sporco e dopo lui ha pedalato velocemente con paura..." [ele andou por um pequeno caminho sem a sua bicicleta, no fim do campo descobre um buraco no qual viu um garoto mais branco, sujo e depois ele pedalou rapidamente com medo...] Nível V.

Cabe considerar que o aluno em sua produção expressou uma sequência de ações e, para tanto, utilizou o passato prossimo, porém, no meio do excerto ainda encontramos um verbo no tempo presente. 


\section{Gráfico 15 - Verbo esserci}

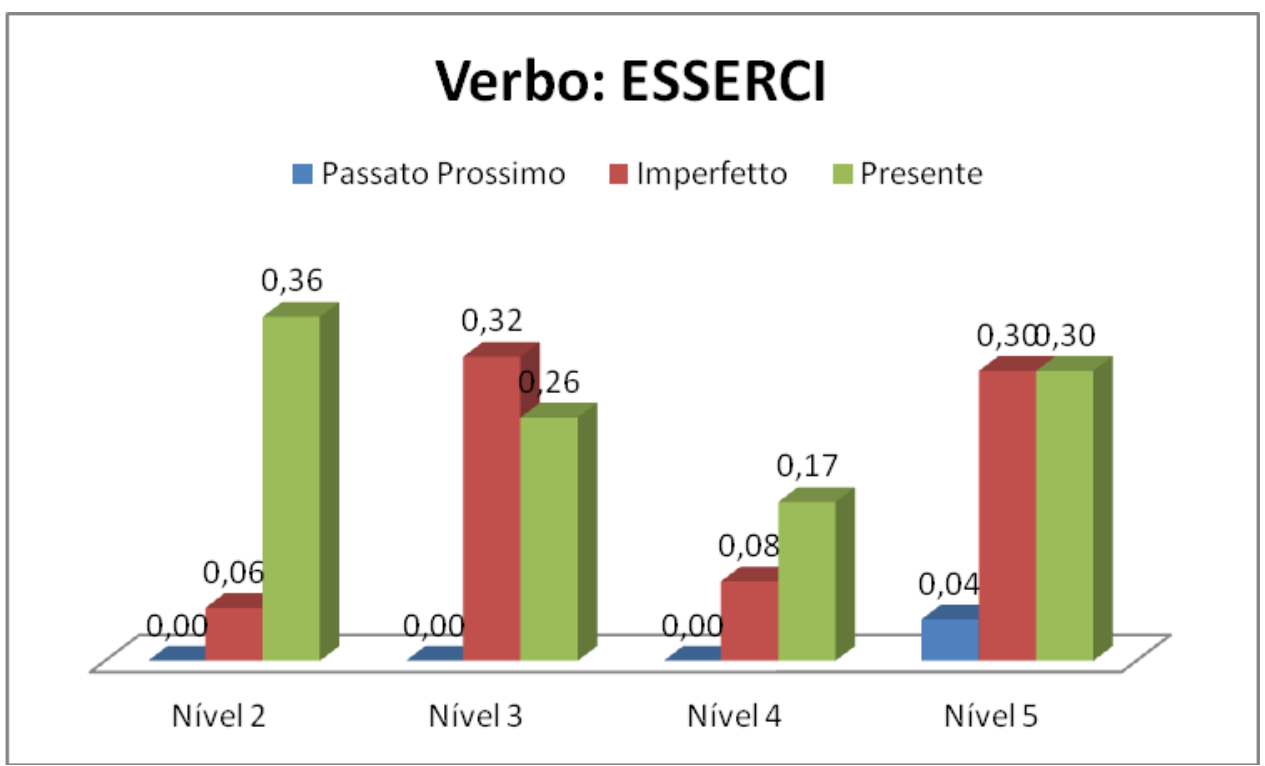

Tabela 6 - Desvio padrão do verbo esserci

\begin{tabular}{|c|c|c|c|c|c|c|c|c|c|c|c|}
\hline \multicolumn{12}{|c|}{ DESVIO PADRÃO } \\
\hline \multicolumn{3}{|c|}{ Nível 2} & \multicolumn{3}{|c|}{ Nível 3} & \multicolumn{3}{|c|}{ Nível 4} & \multicolumn{3}{|c|}{ Nível 5} \\
\hline P.P. & IMP. & PRES. & P.P. & IMP. & PRES. & P.P. & IMP. & PRES. & P.P. & IMP. & PRES. \\
\hline 0 & 0,23 & 0,79 & 0 & 0,66 & 0,67 & 0 & 0,36 & 0,50 & 0,20 & 0,70 & 0,63 \\
\hline
\end{tabular}

O verbo esserci [haver] apresenta os seguintes traços: + duração, - telicidade, dinamicidade. Verificamos que há ocorrência desse verbo no passato prossimo somente no último nível, entretanto, houve o uso reduzido no tempo imperfetto no nível II, cresceu no nível seguinte, diminuiu no nível IV e aumentou no nível V. Cabe evidenciar que o uso do tempo imperfetto superou consideravelmente todas as outras utilizações desse mesmo tempo nos outros verbos observados.

Diferentemente do que pudemos perceber em outros verbos vistos até o momento, o verbo esserci conjugado no tempo presente apresentou uma queda nos níveis intermediários, II e III, e cresceu no último nível equiparando-se ao uso no presente.

Eis alguns exemplos: 
"Michele andava in bicicletta quando ha visto una serpente nel suolo. $\underline{\mathrm{Ci} \text { sono molti }}$ uccelli. (...) $\underline{C^{\prime} \grave{e}}$ una porta..." [Michele andava de bicicleta quando viu uma cobra no chão. Há muitas cobras. (...) Há uma porta] - Nível II.

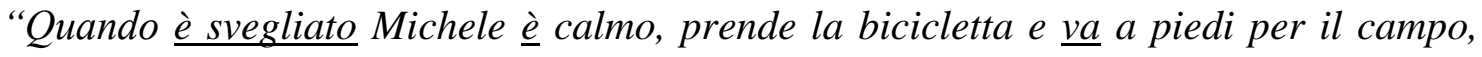

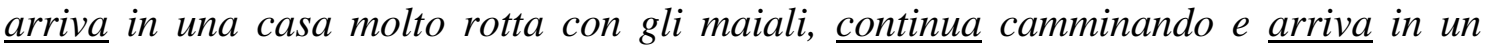
villaggio dove aveva alcuni bambini, moglie e c'era un autocarro dove aveva molti cosi per vendere” [Quando acordou Michele está calmo, pega a bicicleta e vai a pé pelo campo, chega a uma casa muito destruída com os porcos, continua caminhando e chega a uma vila onde tinha alguns meninos, mulher e havia um caminhão onde tinha muitas coisas para vender] - Nível III.

Notamos na produção acima a ocorrência do primeiro verbo no passato prossimo, os seguintes no presente, e a descrição do lugar foi realizada no tempo imperfetto a partir do verbo esserci.

"Michele continua camminando, arriva in un luogo pieno di personi, dove çè un piccolo autocarro..." [Michele continua caminhando, chega em um lugar cheio de pessoas, onde há um pequeno caminhão] - Nível IV.

"Michele andava in bicicletta quando ha visto una casa vecchia, ha cominciato a camminare e quando ha scoperto un buco dove c'era un bambino, è stato spaventato" [Michele andava de bicicleta quando viu uma casa velha, começou a caminhar e quando descobriu um buraco onde havia um menino, ficou assustado] - Nível V.

Podemos ver no último trecho que o aluno combinou na sua produção os tempos do passado a fim de narrar uma sequência de ações e realizar entre elas a descrição do ambiente. 


\section{Gráfico 16 - Verbo continuare}

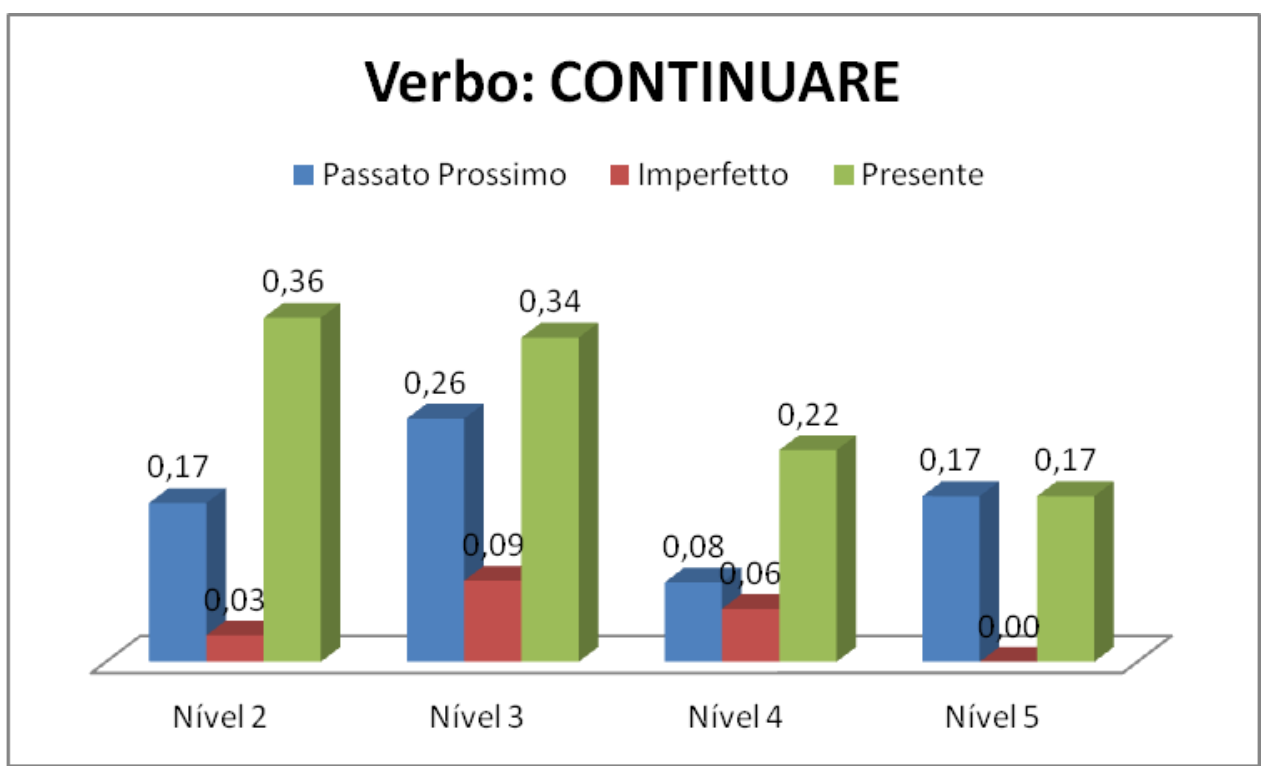

Tabela 7 - Desvio padrão do verbo continuare

\begin{tabular}{|c|c|c|c|c|c|c|c|c|c|c|c|}
\hline \multicolumn{12}{|c|}{ DESVIO PADRÃO } \\
\hline \multicolumn{3}{|c|}{ Nível 2} & \multicolumn{3}{|c|}{ Nível 3} & \multicolumn{3}{|c|}{ Nível 4} & \multicolumn{3}{|c|}{ Nível 5} \\
\hline P.P. & IMP. & PRES. & P.P. & IMP. & PRES. & P.P. & IMP. & PRES. & P.P. & IMP. & PRES. \\
\hline 0,37 & 0,16 & 0,72 & 0,70 & 0,35 & 0,75 & 0,28 & 0,23 & 0,48 & 0,65 & 0 & 0,38 \\
\hline
\end{tabular}

O verbo continuare [continuar], caracterizado pelos traços de + duração, telicidade, - dinamicidade, foi usado, como podemos verificar nos gráficos, semelhantemente ao esserci em relação ao presente, pois apresentou uso decrescente do nível II ao nível IV, entretanto, diferentemente, no nível V, o uso por aluno é menor.

As ocorrências desse verbo no passato prossimo foram marcadas pelo crescimento, pela diminuição, e pelo crescimento, nos níveis III, IV e V, respectivamente. O uso do imperfetto, por sua vez, apesar da baixa recorrência, já aparece no nível II (antes da instrução formal desse tempo); no nível seguinte há um aumento do seu uso por aprendiz, seguido pelo decréscimo no nível IV e da não utilização no quinto nível do curso.

Eis alguns exemplos: 
"Quando è arrivato nel paesino, ha visto le persone del paesino que continuavanno a vivere normalmente senza nessuna preocupazione con il bambino que Michele $\underline{\text { ha }}$ scoperto [Quando chegou à vila, viu as pessoas da vila que continuavam a viver normalmente sem nenhuma preocupação com o menino que Michele descobriu] - Nível II.

Apesar de cursar o segundo nível da língua, o aprendiz já introduziu o imperfetto na sua produção para expressar uma ação de duração no passado e, também, houve utilizações no passato prossimo, uma marca perfectiva, fator importante já que, conforme vimos anteriormente os predicados atélicos apresentam a tendência de serem relacionados, primeiramente, ao aspecto imperfectivo (BANFI E BERNINI: 2003). No próximo exemplo, houve, na produção textual, uma ocorrência do verbo no passato prossimo. $\mathrm{O}$ aprendiz combinou o presente e o passado para expressar a sequência de ações.

"Lui esce correndo con la sua bicicletta, si inciampa e è caduto. Lui si alza e vede che sua bicicletta sta rotta. Lui cammina e avvista un porcaio con molti maiali. Lui ha continuato a camminare fino a trovare un gruppeto di persone" [Ele sai correndo com a sua bicicleta, tropeça e caiu. Ele se levanta e vê que sua bicicleta está quebrada. Ele caminha e avista um chiqueiro com muitos porcos. Ele continuou a caminhar até encontrar um grupinho de pessoas] - Nível III.

“...quindi lui parte di quello luogo spaventado e ha continuato pedalare e la sua bicicletta è caduta in un bucco e lui è lanciato lontano. Lui allora ha continuato nella strada e trova $i$ maialli..." [então ele parte daquele lugar assustado e continuou a pedalar e a sua bicicleta caiu em um buraco e ele foi jogado longe. Ele então continuou na estrada e encontra os porcos] - Nível V. 
Verificamos na narrativa realizada que ainda existe uma mistura dos tempos verbais presente e passado, embora o aprendiz esteja em um nível intermediário.

\section{Gráfico 17 - Verbo essere}

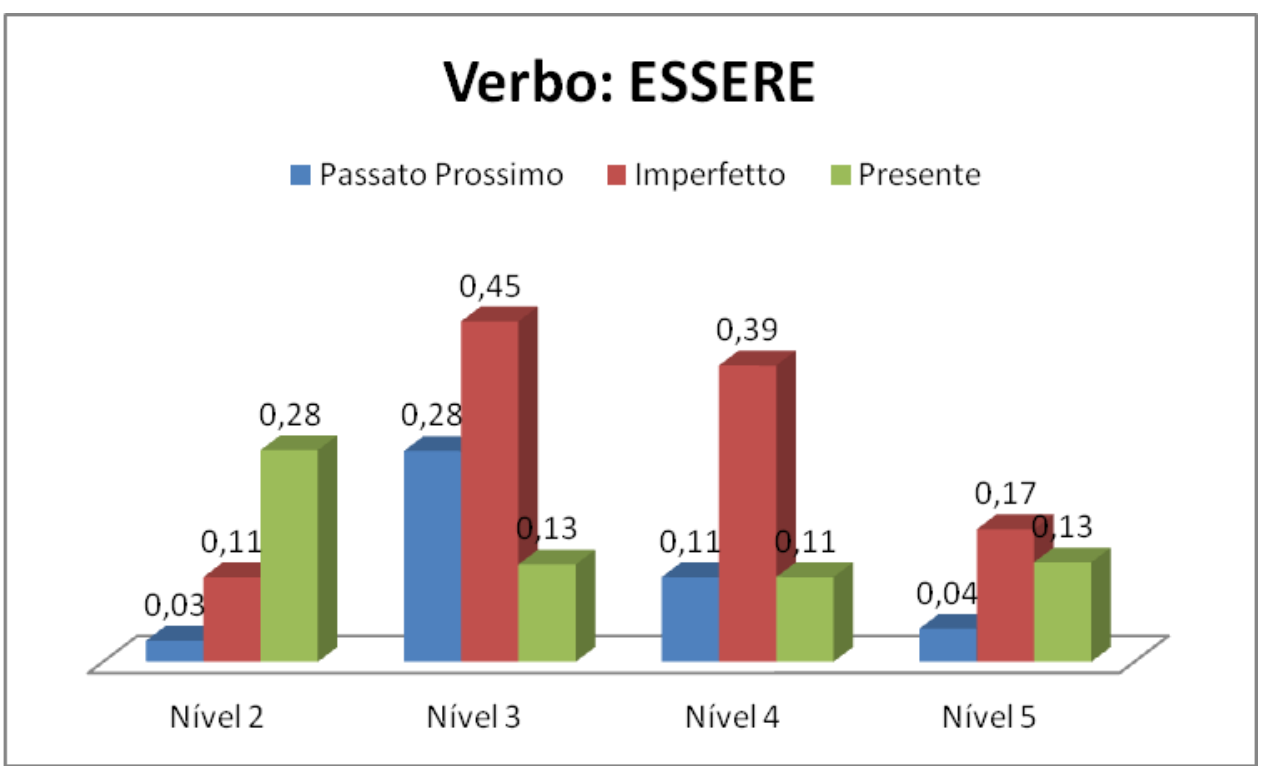

Tabela 8 - Desvio padrão do verbo essere

\begin{tabular}{|c|c|c|c|c|c|c|c|c|c|c|c|}
\hline \multicolumn{12}{|c|}{ DESVIO PADRÃO } \\
\hline \multicolumn{3}{|c|}{ Nível 2} & \multicolumn{3}{|c|}{ Nível 3} & \multicolumn{3}{|c|}{ Nível 4} & \multicolumn{3}{|c|}{ Nível 5} \\
\hline P.P. & IMP. & PRES. & P.P. & IMP. & PRES. & P.P. & IMP. & PRES. & P.P. & IMP. & PRES. \\
\hline 0,16 & 0,52 & 0,65 & 0,61 & 0,77 & 0,33 & 0,31 & 0,59 & 0,31 & 0,20 & 0,38 & 0,34 \\
\hline
\end{tabular}

Os traços do verbo essere [ser] são: + duração, - telicidade, - dinamicidade. O seu uso, com exceção do segundo nível em que se sobrepôs a utilização do tempo presente, ocorreu, sobretudo, no imperfetto. Ainda que não seja um verbo télico, podemos observar também alguma ocorrência do passato prossimo no nível II, porém, no nível seguinte, as ocorrências do verbo essere nesse tempo aumentaram consideravelmente em relação ao nível anterior. A associação de um verbo atélico à marca perfectiva, como vimos, é considerada pelos autores Andersen e Shirai (1996) posterior à associação do mesmo verbo à imperfectividade. 
Em relação à utilização do imperfetto no nível II, cabe lembrar que tal forma não havia sido abordada explicitamente em sala de aula, mas que é semelhante ao uso do tempo pretérito imperfeito do português brasileiro.

“...in questo luogo lui ha trovato suo padre cui comincia da litigare con lui perché non capeva come Michele era tanto lontano della casa..." [neste lugar ele encontrou seu pai e começa a brigar com ele porque não entendia como Michele era tão longe de casa] Nível II.

“... ha visto una serpente morta. Lui è stato molto spaventato con la visione della serpente [...] dopo altri metri lui ha visto molte persone che erano adulte..." [...viu uma cobra morta. Ele ficou muito assustado com a visão da cobra [...] depois de outros metros ele viu muitas pessoas que eram adultas] - Nível III.

No texto acima, observamos que o aprendiz combinou as marcas de perfectividade e imperfectividade no mesmo verbo com o objetivo de provocar dois efeitos diferentes em que a primeira ação apesar de ser um predicado que exprime estado "è stato", assumiu interpretação dinâmica e foi usado no passato prossimo, a segunda, entretanto, exprimiu estado e duratividade, logo foi utilizada no imperfetto. 


\section{Gráfico 18 - Verbo cadere}

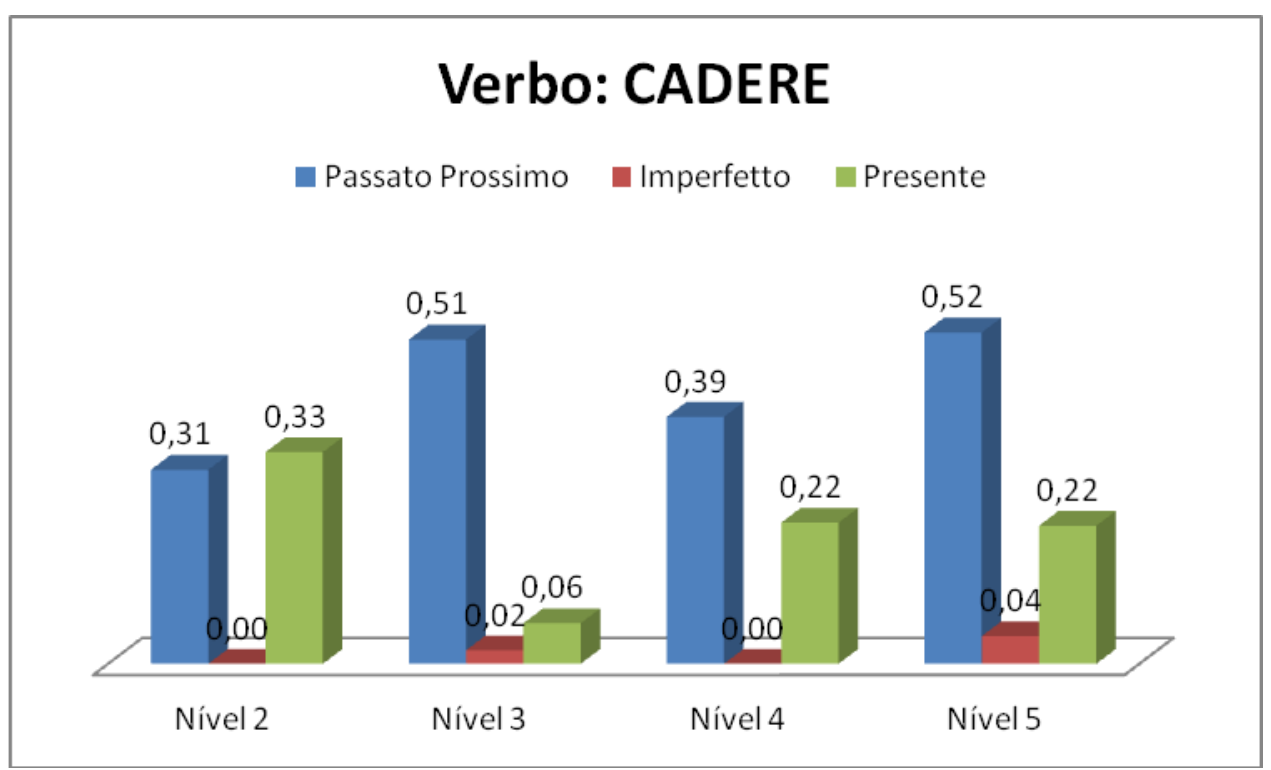

Tabela 9 - Desvio padrão do verbo cadere

\begin{tabular}{|c|c|c|c|c|c|c|c|c|c|c|c|}
\hline \multicolumn{12}{|c|}{ DESVIO PADRÃO } \\
\hline \multicolumn{3}{|c|}{ Nível 2} & \multicolumn{3}{|c|}{ Nível 3} & \multicolumn{3}{|c|}{ Nível 4} & \multicolumn{3}{|c|}{ Nível 5} \\
\hline P.P. & IMP. & PRES. & P.P. & IMP. & \begin{tabular}{|l} 
PRES. \\
\end{tabular} & P.P. & IMP. & PRES. & P.P. & IMP. & PRES. \\
\hline 0,46 & 0 & 0,47 & 0,50 & 0,14 & 0,24 & 0,49 & 0 & 0,54 & 0,59 & 0,20 & 0,28 \\
\hline
\end{tabular}

O verbo cadere [cair] é caracterizado pelos traços de - duração, + dinamicidade, + telicidade. Observamos, através dos gráficos, que já no nível II, o uso desse verbo no passato prossimo não foi consideravelmente diferente do que ocorreu com o presente. Os gráficos também evidenciam a pouca recorrência do verbo no presente em todos os níveis subsequentes se comparado a sua utilização no passato prossimo, ou seja, o uso foi frequente na marca perfectiva.

Lembramos que o verbo cadere é télico e, conforme já dissemos, Andersen e Shirai (1996) apontam o uso das marcas do passado perfectivo a esse tipo de predicado. Por outro lado, a associação do mesmo verbo à marca imperfectiva foi baixa nas produções escritas.

"Ha preso la sua bicicletta e ha pedalato il massimo che era troppo veloce. Tanto, tanto veloce che non ha visto bene il camino e è caduto, con la faccia per terra. Quando 
Michele si sveglia, prende la bicicletta..." [Pegou a bicicleta e pedalou o máximo que era capaz. Tão, tão rápido que não viu bem o caminho e caiu, com o rosto no chão. Quando Michele acorda, pega a bicicleta...] - Nível II.

Outra característica importante pode ser observada no nível III em que se percebe uma grande diferença entre a recorrência dos verbos no passato prossimo e no tempo presente. Essa diferença de que falamos diminuiu no nível IV e aumentou no nível V.

\section{Gráfico 19 - Verbo aprire}

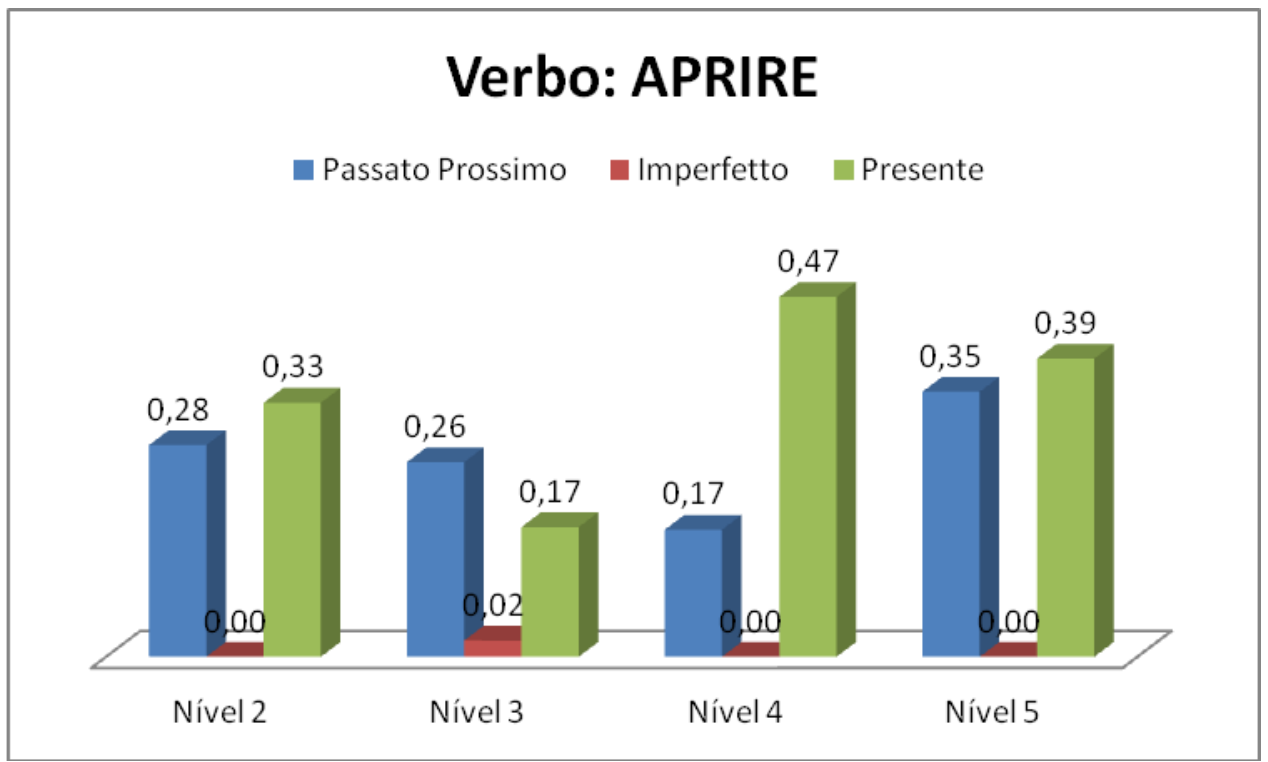

Tabela 10 - Desvio padrão do verbo aprire

\begin{tabular}{|c|c|c|c|c|c|c|c|c|c|c|c|}
\hline \multicolumn{12}{|c|}{ DESVIO PADRÃO } \\
\hline \multicolumn{3}{|c|}{ Nível 2} & \multicolumn{3}{|c|}{ Nível 3} & \multicolumn{3}{|c|}{ Nível 4} & \multicolumn{3}{|c|}{ Nível 5} \\
\hline P.P. & IMP. & PRES. & P.P. & IMP. & PRES. & P.P. & IMP. & PRES. & P.P. & IMP. & PRES. \\
\hline 0,56 & 0 & 0,63 & 0,53 & 0,14 & 0,43 & 0,44 & 0 & 0,69 & 0,64 & 0 & 0,65 \\
\hline
\end{tabular}

Os traços do verbo aprire [abrir] são: + duração, + dinamicidade e + telicidade. O seu uso no tempo presente foi semelhante àqueles que observamos com os verbos télicos vedere e camminare, pois os gráficos nos mostram que houve uma queda no 
nível III se comparado ao nível anterior, houve o aumento do seu uso no nível IV e uma pequena diminuição no nível V.

O uso do verbo no passato prossimo foi um pouco menor no nível III em relação ao nível II, houve queda da sua utilização também no nível IV, entretanto, no nível V, o seu uso subiu, podendo quase ser comparado à sua utilização no presente.

A maior diferença pode ser observada no nível IV em que o uso do presente supera consideravelmente o uso do mesmo verbo no passato prossimo, característica também notada com os verbos já analisados até aqui, isto é, camminare, pedalare, esserci e continuare.

Não foi verificado o uso desse verbo no tempo imperfetto, com exceção da sua baixa ocorrência no nível III.

Gráfico 20 - Verbo lanciare

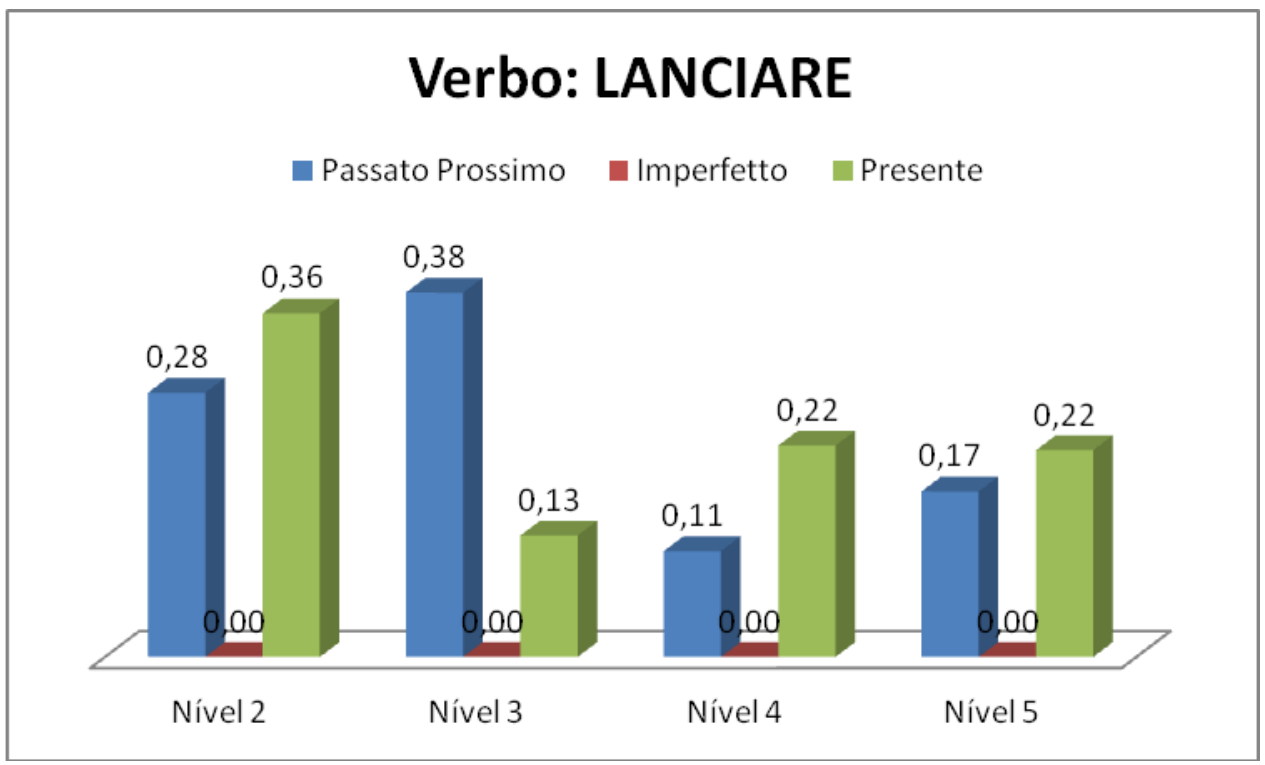

Tabela 11 - Desvio padrão do verbo lanciare

\begin{tabular}{|c|c|c|c|c|c|c|c|c|c|c|c|}
\hline \multicolumn{12}{|c|}{ DESVIO PADRÃO } \\
\hline \multicolumn{3}{|c|}{ Nível 2} & \multicolumn{3}{|c|}{ Nível 3} & \multicolumn{3}{|c|}{ Nível 4} & \multicolumn{3}{|c|}{ Nível 5} \\
\hline P.P. & IMP. & PRES. & P.P. & IMP. & \begin{tabular}{|l} 
PRES. \\
\end{tabular} & P.P. & IMP. & PRES. & P.P. & IMP. & PRES. \\
\hline 0,51 & 0 & 0,63 & 0,53 & 0 & 0,33 & 0,39 & 0 & 0,48 & 0,38 & 0 & 0,42 \\
\hline
\end{tabular}


O verbo lanciare [jogar] caracterizado pelos traços de + duração, + dinamicidade e + telicidade foi bastante utilizado nas produções dos aprendizes nos tempos presente e passato prossimo. Não houve nenhuma recorrência do seu uso no imperfetto.

Houve o crescimento do seu uso por aluno no nível III, a diminuição no nível seguinte e um pequeno aumento da sua utilização no nível V se comparado ao anterior. Novamente, podemos observar o crescimento do uso do passato prossimo no nível III, conforme percebemos nos verbos vedere, camminare, continuare, essere e cadere, a queda do passato prossimo no nível IV e o seu aumento no nível V. Apesar disso, o uso do presente, semelhantemente ao verbo aprire, se sobrepôs ao passato prossimo nos níveis IV e V.

Notamos na produção abaixo a combinação dos tempos imperfetto e passato prossimo:

"Lui ha accorto che uno bambino era giù, preso nel pozzo. Ha lanciato una pietra e quando il bambino lo occhia..." [Ele percebeu que um menino estava embaixo, preso no poço. Jogou uma pedra e quando o menino o “olha”...] - Nível III. 


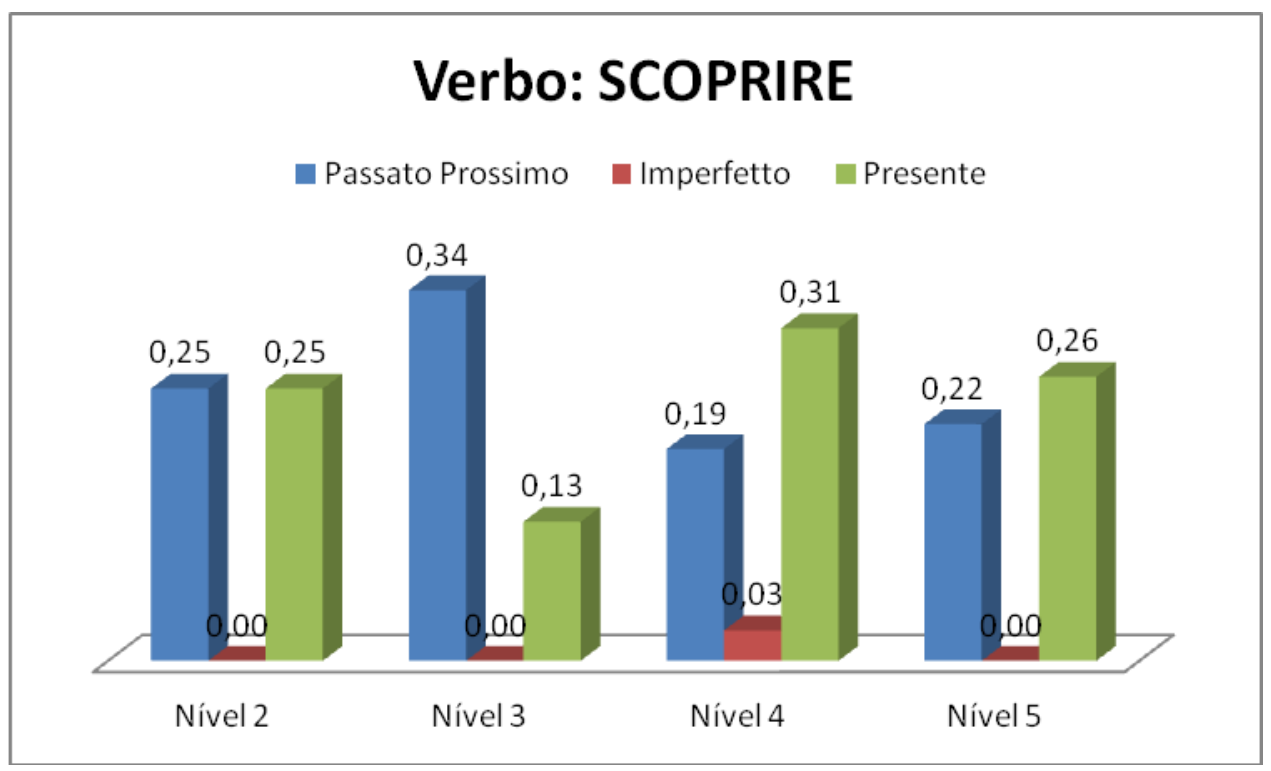

Tabela 12 - Desvio padrão do verbo scoprire

\begin{tabular}{|c|c|c|c|c|c|c|c|c|c|c|c|}
\hline \multicolumn{12}{|c|}{ DESVIO PADRÃO } \\
\hline \multicolumn{3}{|c|}{ Nível 2} & \multicolumn{3}{|c|}{ Nível 3} & \multicolumn{3}{|c|}{ Nível 4} & \multicolumn{3}{|c|}{ Nível 5} \\
\hline P.P. & IMP. & PRES. & P.P. & IMP. & PRES. & P.P. & IMP. & PRES. & P.P. & IMP. & PRES. \\
\hline 0,60 & 0 & 0,5 & 0,56 & 0 & 0,39 & 0,40 & 0,16 & 0,57 & 0,51 & 0 & 0,44 \\
\hline
\end{tabular}

As características do verbo scoprire [descobrir] são: - duração, + dinamicidade, + telicidade. É interessante perceber nos gráficos acima que, no nível II, o uso do passato prossimo e do presente foi igual. No nível seguinte, as ocorrências do verbo no passato prossimo por aluno ultrapassaram o presente e, ocorreu, exatamente, o contrário, no nível IV. No nível V, as ocorrências do presente também superaram o passato prossimo, porém com pouca diferença. A utilização do imperfetto ocorreu somente em baixa quantidade por aluno no nível IV. Conforme observamos em outros verbos, a ocorrência do passato prossimo é maior no nível III e menor no nível seguinte. Consideramos também que é um verbo télico, cujo traço é de - duração, e notamos a tendência em associá-lo à marca perfectiva. 
Eis um exemplo das produções textuais do mesmo aluno nos níveis II e III. Se no primeiro teste a que foi submetido, o aprendiz utilizou o tempo presente na narrativa, no nível seguinte foi capaz de utilizar a marca perfectiva.

"Lui camina verso la casa e scopre un pozzo coperto con una porta" [Ele caminha em diração à casa e descobre um poço coberto por uma porta] - Nível II.

“Curioso lui è aperto un po' e ha scoperto un pozzo dove ha potuto vedere un piede" [Curioso ele abriu um pouco e descobriu um poço onde pôde ver um pé] - Nível III.

Gráfico 22 - Verbo arrivare

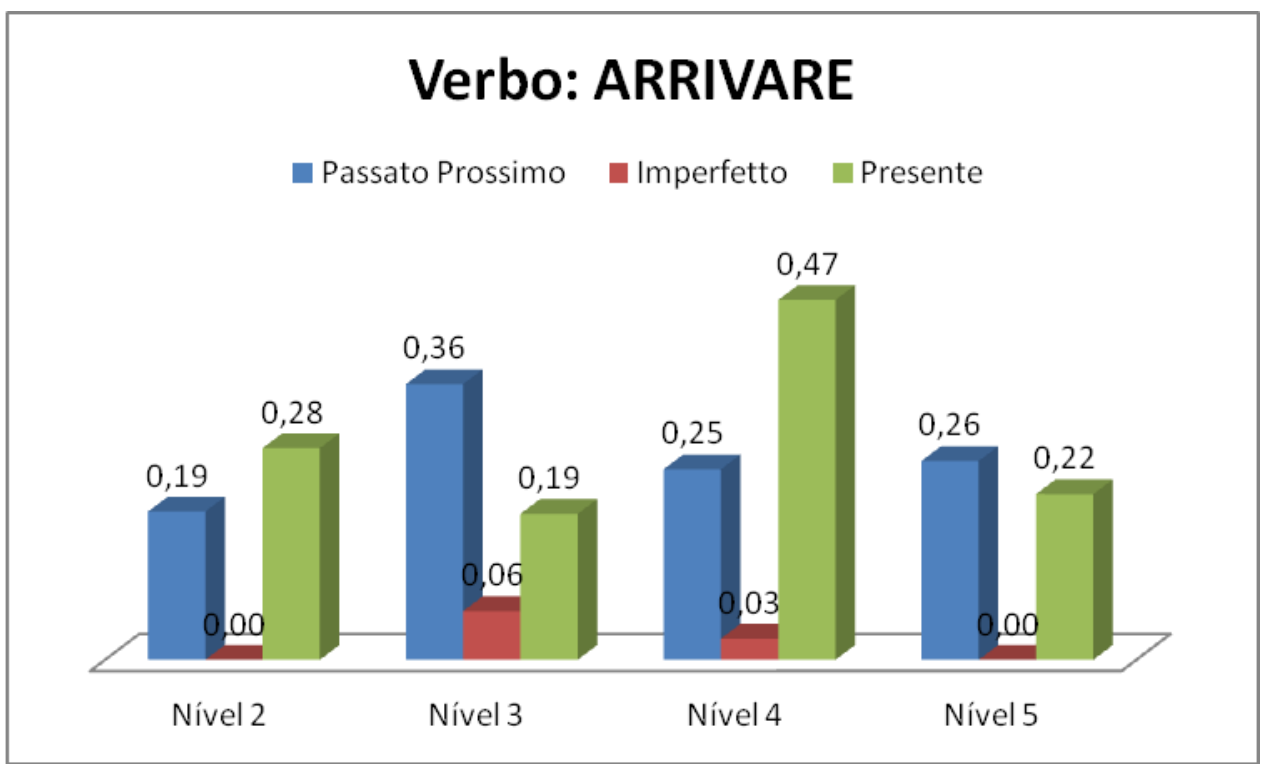

Tabela 13 - Desvio padrão do verbo arrivare

\begin{tabular}{|c|c|c|c|c|c|c|c|c|c|c|c|}
\hline \multicolumn{12}{|c|}{ DESVIO PADRÃO } \\
\hline \multicolumn{3}{|c|}{ Nível 2} & \multicolumn{3}{|c|}{ Nível 3} & \multicolumn{3}{|c|}{ Nível 4} & \multicolumn{3}{|c|}{ Nível 5} \\
\hline P.P. & IMP. & PRES. & P.P. & IMP. & PRES. & P.P. & IMP. & PRES. & P.P. & IMP. & PRES. \\
\hline 0,40 & 0 & 0,56 & 0,48 & 0,32 & 0,44 & 0,5 & 0,16 & 0,84 & 0,44 & 0 & 0,42 \\
\hline
\end{tabular}

O verbo arrivare [chegar] possui os traços de - duração, + dinamicidade, + telicidade. O tempo presente superou o uso do passato prossimo nos níveis II e IV. Observamos que o uso do imperfetto por parte dos aprendizes ocorreu apenas nos níveis 
III e IV, mas o seu uso foi baixo. Assim como aconteceu com grande parte dos verbos analisados houve um crescimento da utilização da marca perfectiva no terceiro nível, fator que diminuiu no nível IV. No nível V, a ocorrência permaneceu quase igual. Os verbos scoprire e arrivare apresentam os mesmo traços e, se comparados, os gráficos apresentam em relação ao passato prossimo as mesmas características de uso: ocorrências no nível II, logo após a instrução formal, aumento desse uso no nível seguinte e diminuição dele no quarto nível da língua.

Podemos notar através do exemplo abaixo que apesar da maioria das ocorrências desse verbo serem associadas à marca perfectiva, houve alguns usos em que o verbo télico foi associado à marca imperfectiva:

"quando arrivava a casa, cercava alcuna cosa diversa e quando ha deciso aprire la tegola (...) quando è arrivato nel vostro villaggio ha visto che tutti stavano abbastanza bene..." [quando chegava a casa, procurava alguma coisa diferente e quando decidiu abrir a telha (...) quando chegou à vossa vila, viu que todos estavam muito bem...] - Nível III.

Notamos também através do excerto que a palavra "quando" que, geralmente, estimula o uso de um verbo perfectivo, foi associado tanto a essa marca quanto à imperfectiva, dependendo do efeito que o aprendiz objetiva criar em sua produção. 


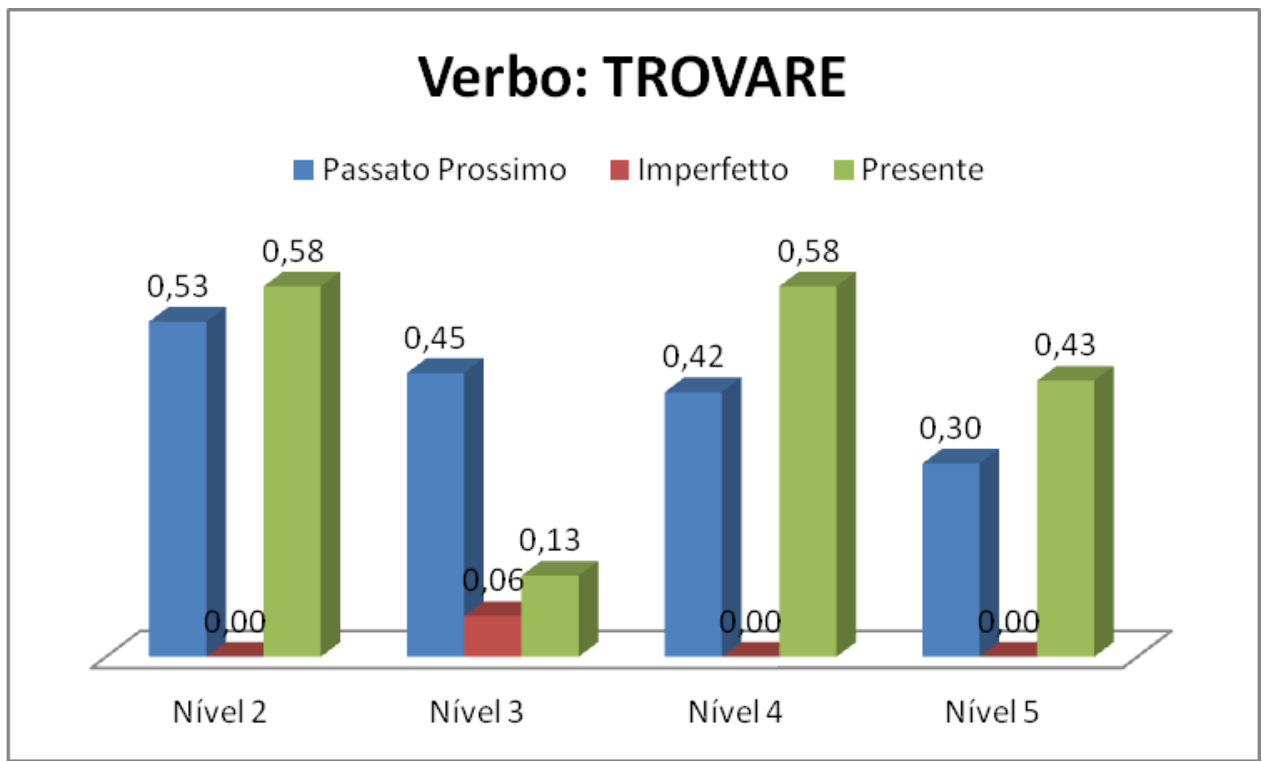

Tabela 14 - Desvio padrão do verbo trovare

\begin{tabular}{|c|c|c|c|c|c|c|c|c|c|c|c|}
\hline \multicolumn{12}{|c|}{ DESVIO PADRÃO } \\
\hline \multicolumn{3}{|c|}{ Nível 2} & \multicolumn{3}{|c|}{ Nível 3} & \multicolumn{3}{|c|}{ Nível 4} & \multicolumn{3}{|c|}{ Nível 5} \\
\hline P.P. & IMP. & PRES. & P.P. & IMP. & PRES. & P.P. & IMP. & PRES. & P.P. & IMP. & PRES. \\
\hline 0,99 & 0 & 0,80 & 0,74 & 0,24 & 0,44 & 0,80 & 0 & 0,99 & 0,47 & 0 & 0,89 \\
\hline
\end{tabular}

Os traços do verbo trovare [encontrar] são: - duração, + dinamicidade, + telicidade. O seu uso difere do verbo arrivare em relação à maior utilização por aprendiz no último nível em que a sua utilização no tempo presente superou o uso no passato prossimo. Porém, no que concerne aos três primeiros níveis em que os testes foram realizados, a utilização foi semelhante. Houve maior ocorrência no nível II do verbo no tempo presente, porém, assim como aconteceu com o verbo scoprire, as diferenças entre os dois tempos, presente e passato prossimo, não são tão grandes. No nível seguinte, porém, o uso do passato prossimo superou notavelmente o uso do tempo presente e, no nível IV, cresceu o uso do tempo presente em detrimento da queda do passato prossimo.

O uso do imperfetto, por sua vez, apareceu somente no nível III. 
"Michele andava in bicicletta quando ha trovato una vipera morta" [Michele andava de bicicleta quando encontrou uma víbora morta] - nível II.

"Michele pedalava sua bicicletta in un campo di grano, in una stradina, quando arriva a un posto dove si trova una casa antica" [Michele pedalava a sua bicicleta em um campo de trigo, em uma estradinha, quando chega a um lugar em que encontra uma casa antiga] - Nível IV.

Muitas das ocorrências, como dissemos, foram no passato prossimo, porém, como podemos observar no segundo excerto, muitos dos usos, principalmente, no nível IV da língua, voltam a ocorrer no presente.

\subsubsection{Os resultados da produção escrita}

$\mathrm{Na}$ atividade de produção escrita, conforme já dissemos, os alunos foram orientados a continuarem um texto que apresentava marcas temporais indicadoras do passado e, logo, para manter a coerência textual, os alunos poderiam utilizar, para descrever as ações realizadas pelo protagonista do filme, verbos no passado, tanto perfectivo quanto imperfectivo, dependendo do tipo de efeito que gostariam de criar no discurso.

Entretanto, visto que nosso objetivo não era atribuir julgamento de "certo" ou “errado" às escolhas realizadas pelo aprendiz, mas observar quais seriam elas e associálas à telicidade verbal e ao aprendizado explícito e implícito, os dados nos forneceram elementos por meio dos quais pudemos chegar às seguintes observações.

O tempo presente consolidou-se como característica de todos os verbos no nível II, o primeiro em que os alunos foram submetidos aos testes, com exceção apenas do 
cadere [cair]. Tal fato nos permite formular a hipótese de que, não obstante os aprendizes tenham sido expostos à aprendizagem explícita do passato prossimo, como estrutura mais próxima do momento em que realizaram o teste, o conhecimento explícito não foi suficiente para garantir o seu uso imediato nas produções. Assim sendo e partindo do pressuposto de que, antes de chegarem ao segundo nível do curso, os alunos se limitaram por um inteiro semestre de 45 horas, à estrutura verbal do tempo presente do indicativo, é possível entender que eles continuem preferindo a utilização dessa forma verbal já assimilada, pois sabem que, através dela, é possível a comunicação em língua italiana.

Nesse período do teste, as únicas ocorrências do tempo imperfetto, forma verbal não aprendida explicitamente naquele momento do percurso da aquisição da L2, foram com os verbos esserci [haver] $(0,06)$, essere [ser] 0,11 e continuare [continuar] 0,03. O índice de ocorrência por aluno é baixo, mas o fator interessante se relaciona aos traços desses verbos, pois os três apresentam as mesmas características de + duração, telicidade e - dinamicidade. Sabemos que segundo a teoria de Banfi e Bernini (2003) e Andersen e Shirai (1996) existe a tendência de associar primeiro os predicados télicos ao aspecto perfectivo e, ao contrário, os atélicos, ao imperfectivo, porém, apesar de termos observado que somente os verbos atélicos foram associados à marca imperfectiva, acreditamos que os índices que mostraram as suas ocorrências foram baixos se comparados ao uso do presente nessas mesmas situações. A conjugação justamente dos verbos essere e esserci no tempo imperfetto, embora apresente baixos índices, pode nos levar a pensar que, como se trata de verbos muito utilizados, talvez os aprendizes ainda que não tenham recebido instruções explícitas sobre esse tempo, podem tê-lo ouvido, na forma input, favorecendo o seu aparecimento. 
No terceiro nível do curso, os alunos haviam recebido a carga de um semestre de uso, exercícios de sistematização das regras, e produções orais e escritas que incentivavam o uso do passato prossimo e, nos testes e nos gráficos obtidos, percebemos que o uso da marca perfectiva foi escolhida na maioria dos verbos como, por exemplo, vedere [ver], cadere [cair], aprire [abrir], lanciare [jogar], scoprire [descobrir], arrivare [chegar], trovare [encontrar]. Com exceção do primeiro verbo citado, todos os outros possuem o traço de + telicidade e foram associados, sobretudo, ao aspecto perfectivo. Cabe considerar que esses mesmos, mesmo após o aprendizado explícito, foram usados pela grande maioria dos aprendizes apenas após um semestre.

No mesmo teste, os verbos atélicos foram conjugados, principalmente no tempo presente e no imperfetto, mas as diferenças entre os seus índices não são muito significativas, com exceção do verbo essere [ser] que apresentou índice de 0,45 na marca imperfectiva, 0,28 na perfectiva e 0,13 de uso por aprendiz no tempo presente. Consideramos pertinente ressaltar que nos resultados concernentes a esse verbo, os maiores índices relacionam-se à escolha das marcas perfectivas e imperfectivas e, não obstante seja um verbo que apresenta caráter de + duração, - dinamicidade e telicidade, foi associado por alguns ao passato prossimo.

Naquilo que se refere às tarefas aplicadas aos alunos quando eles cursavam o nível IV do curso de italiano, os resultados nos surpreenderam, pois o uso do tempo presente voltou a crescer nas produções textuais, inclusive com os verbos télicos que haviam sido associado ao passato prossimo no nível precedente. Somente o verbo cadere [cair] foi conjugado em maior índice no passato prossimo, e o verbo essere [ser] relacionado ao imperfetto, todos os outros foram associados ao presente. Podemos levantar a hipótese que talvez, por não aparecerem no material didático adotado pelo curso atividades e exercícios que retomem a utilização dessas estruturas, os aprendizes 
sejam levados a recorrer ao principal tempo verbal que utilizaram para se expressar desde o primeiro nível do curso, ou seja, o presente.

No último nível do teste, ainda se referindo aos textos produzidos pelos aprendizes, notamos que, os verbos télicos aprire [abrir], lanciare [jogar], scoprire [descobrir], arrivare [chegar], trovare [encontrar] apresentaram índices de usos muito próximos entre eles com relação ao tempo presente e ao passato prossimo, o que também ocorreu com o verbo atélico continuare [continuar]. Dos verbos atélicos somente esserci [haver] e essere [ser] mostraram resultados quase iguais de uso no presente e no imperfetto. Por outro lado, os verbos vedere [ver], pedalare [pedalar] e cadere [cair] mostraram um elevado número de recorrências no presente.

Em suma, nesta primeira atividade, pudemos observar que os alunos manifestam a tendência de utilizar o presente para se expressarem nas produções escritas livres, ainda que tenham sido submetidos ao ensino explícito da marca perfectiva, isto é, o passato prossimo, tempo verbal que apareceu em um maior número de ocorrências nos textos dos alunos de nível III, mais distantes - tanto no tempo, quanto em relação às atividades propostas pelo livro didático - da instrução explícita do tempo presente. Em especial, os verbos que apresentam características télicas, nesse contexto, foram associados à marca perfectiva, enquanto os outros foram marcados pelo uso do imperfetto ou do presente. No nível posterior, nove verbos do total de doze voltaram a ser conjugados no tempo presente, marca que ainda é expressiva no nível $\mathrm{V}$, apesar de se aproximarem ou serem superadas pelo uso da marca perfectiva. $\mathrm{O}$ único verbo para o qual se escolheu a marca imperfectiva desde o nível III foi o verbo essere [ser] e isso pode ter sido motivada pela exposição mais frequente a esse verbo.

Com base nesses resultados obtidos em contexto específico, notamos que existe uma oscilação na utilização dos tempos verbais, ainda que os alunos sejam expostos à 
aprendizagem explícita e, no geral, às estruturas relacionadas à marca perfectiva aparecem com maior frequência no nível III e no nível $\mathrm{V}$, especialmente ligadas aos predicados télicos. 


\section{GRÁFICOS 2ª ATIVIDADE DA PESQUISA}

Gráfico 24 - Verbo partire

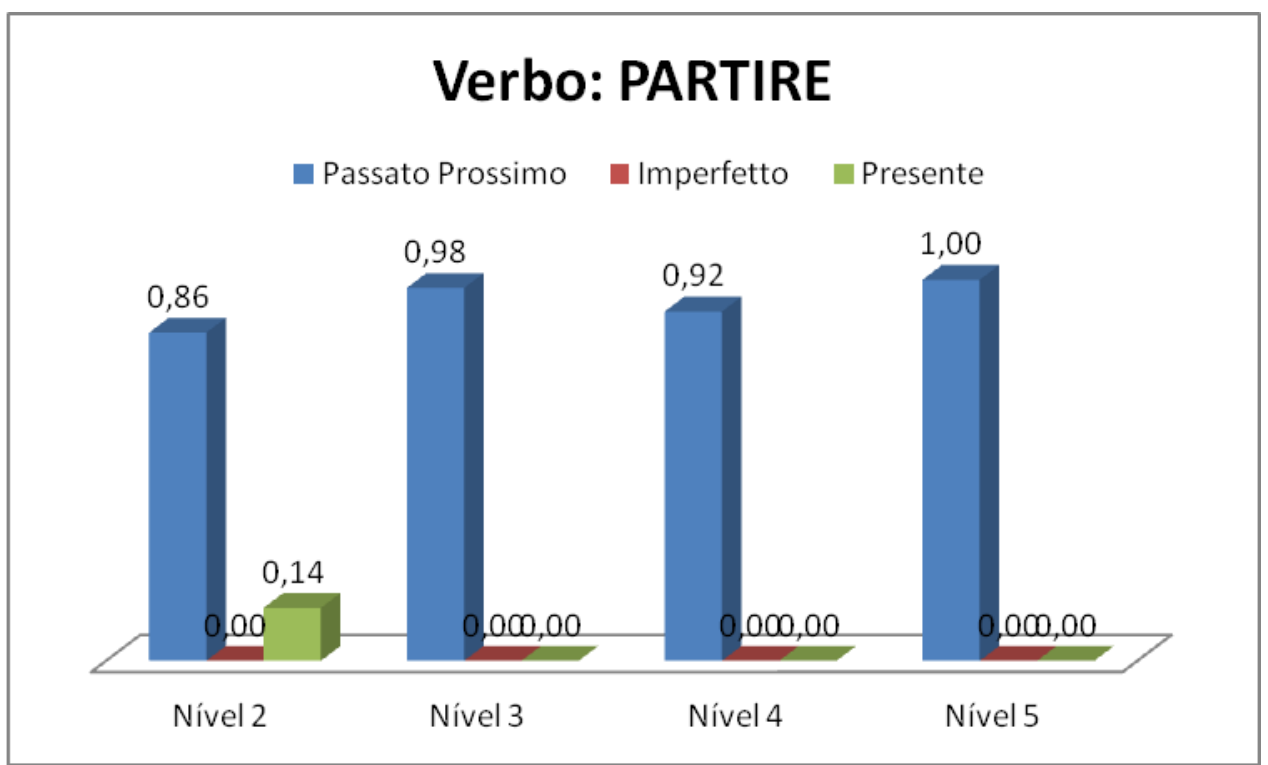

Tabela 15 - Desvio padrão do verbo partire

\begin{tabular}{|c|c|c|c|c|c|c|c|c|c|c|c|}
\hline \multicolumn{12}{|c|}{ DESVIO PADRÃO } \\
\hline \multicolumn{3}{|c|}{ Nível 2} & \multicolumn{3}{|c|}{ Nível 3} & \multicolumn{3}{|c|}{ Nível 4} & \multicolumn{3}{|c|}{ Nível 5} \\
\hline P.P. & IMP. & PRES. & P.P. & IMP. & PRES. & P.P. & IMP. & PRES. & P.P. & IMP. & PRES. \\
\hline 0,35 & 0 & 0,35 & 0,15 & 0 & 0 & 0,28 & 0 & 0 & 0 & 0 & 0 \\
\hline
\end{tabular}

O verbo partire [partir], que assume os traços de - duração, + dinamicidade e + telicidade, foi utilizado na maioria das ocorrências por aluno no passato prossimo. Cabe considerar que esse uso aconteceu ainda no primeiro teste a que os alunos foram submetidos, momento seguinte ao aprendizado explícito dessa forma linguística. É interessante notar que ainda nesse primeiro nível, houve alguns usos do verbo no tempo presente, fato não recorrente nos outros níveis. 


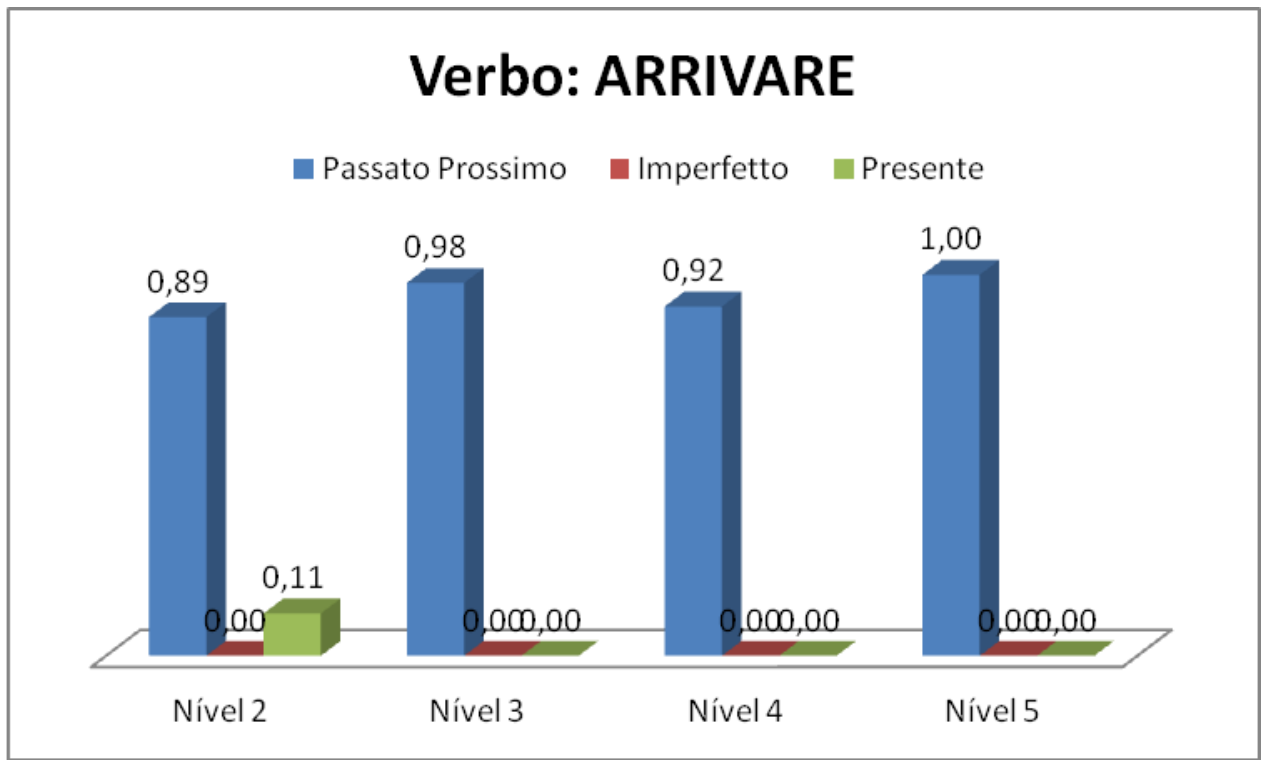

Tabela 16 - Desvio padrão do verbo arrivare

\begin{tabular}{|c|c|c|c|c|c|c|c|c|c|c|c|}
\hline \multicolumn{12}{|c|}{ DESVIO PADRÃO } \\
\hline \multicolumn{3}{|c|}{ Nível 2} & \multicolumn{3}{|c|}{ Nível 3} & \multicolumn{3}{|c|}{ Nível 4} & \multicolumn{3}{|c|}{ Nível 5} \\
\hline P.P. & IMP. & PRES. & P.P. & IMP. & PRES. & P.P. & IMP. & PRES. & P.P. & IMP. & PRES. \\
\hline 0,32 & 0 & 0,32 & 0,15 & 0 & 0 & 0,28 & 0 & 0 & 0 & 0 & 0 \\
\hline
\end{tabular}

Assim como o verbo anterior, arrivare [chegar] assume os mesmos traços: duração, + dinamicidade, + telicidade. O uso do verbo por aluno foi semelhante ao verbo partire, já que, por meio dos gráficos, observamos uma baixa ocorrência do tempo presente no nível II, contrastando com o elevado uso do verbo no passato prossimo, tempo usado exclusivamente nos níveis seguintes do curso com esse verbo. 


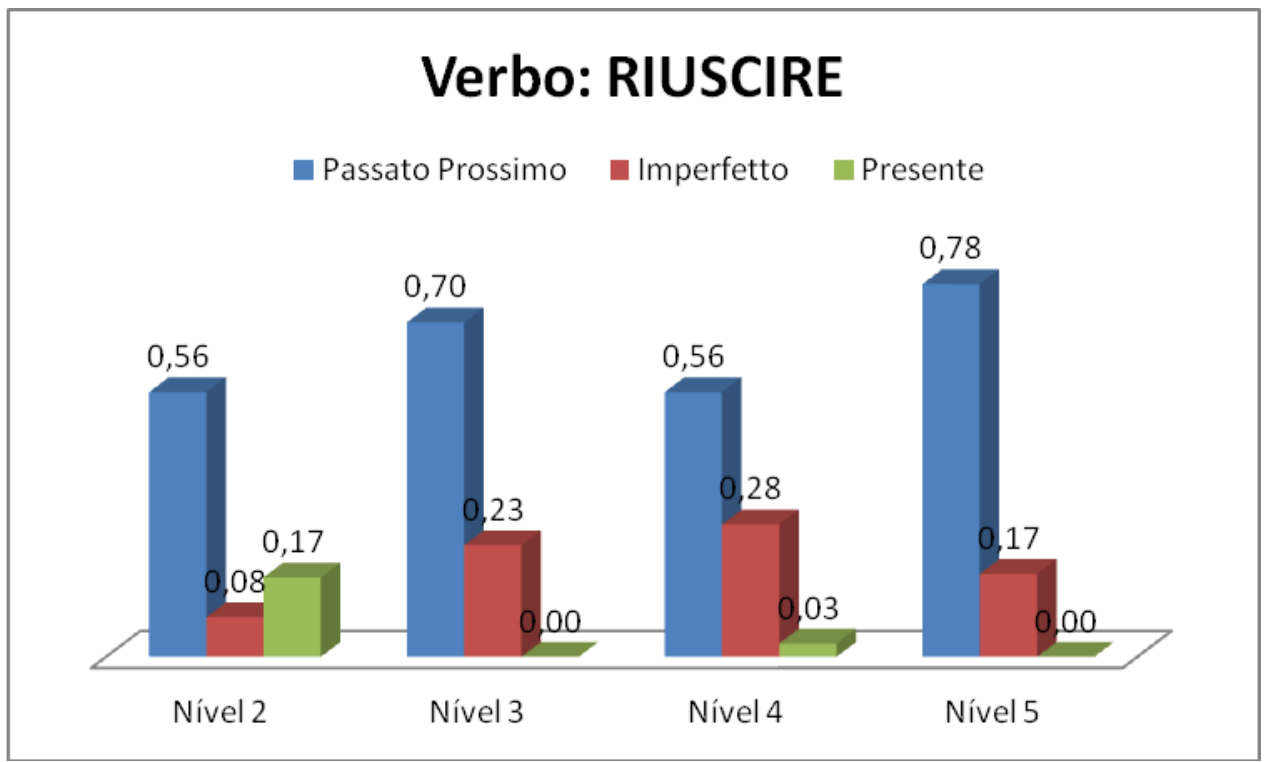

Tabela 17 - Desvio padrão do verbo riuscire

\begin{tabular}{|c|c|c|c|c|c|c|c|c|c|c|c|}
\hline \multicolumn{12}{|c|}{ DESVIO PADRÃO } \\
\hline \multicolumn{3}{|c|}{ Nível 2} & \multicolumn{3}{|c|}{ Nível 3} & \multicolumn{3}{|c|}{ Nível 4} & \multicolumn{3}{|c|}{ Nível 5} \\
\hline P.P. & IMP. & PRES. & P.P. & IMP. & \begin{tabular}{|l|} 
PRES. \\
\end{tabular} & P.P. & IMP. & PRES. & P.P. & IMP. & PRES. \\
\hline 0,20 & 0,28 & 0,38 & 0,46 & 0,43 & 0 & 0,50 & 0,45 & 0,17 & 0,42 & 0,39 & 0 \\
\hline
\end{tabular}

O uso do verbo riuscire [conseguir], caracterizado pelos traços de - duração, + dinamicidade e + telicidade, mostrou resultados interessantes. Na produção textual original, o verbo foi conjugado no imperfetto, expressando uma ação em curso no passado "Non riuscivo a vedere la fine delle migliaia di luci della città" [Non conseguia ver o final das milhares de luzes da cidade]. Primeiramente, podemos observar que o uso no tempo presente, apesar de baixo, foi superior ao encontrado nos dois verbos analisados anteriormente, entretanto, esse fenômeno ocorreu apenas no nível II; no nível IV, o verbo voltou a aparecer no tempo presente, porém o seu uso por aluno foi pouco recorrente.

Houve um contraste entre o uso do passato prossimo e do imperfetto. Ainda que o primeiro tempo tenha sido mais frequente nas produções, entre os níveis III e IV, observamos a queda do uso da marca perfectiva e, ao contrário, o aumento da marca 
imperfectiva. Outro elemento relevante mostrado nos gráficos é a ocorrência do verbo riuscire no tempo imperfetto ainda no nível II do curso de língua, momento em que, cabe lembrar, os alunos não haviam aprendido formalmente o tempo imperfetto.

No quinto nível do curso, houve maior utilização do tempo passato prossimo em detrimento da queda da marca imperfectiva.

Vale considerar que o verbo riuscire faz parte do grupo de verbos télicos, especificamente daqueles chamados de transformativos, e a sua tendência é de ser relacionado à marca perfectiva primeiramente, para depois, associá-lo à marca imperfectiva. Esse fenômeno ocorreu, sobretudo, nos níveis intermediários do teste.

\section{Gráfico 27 - Verbo prendere}

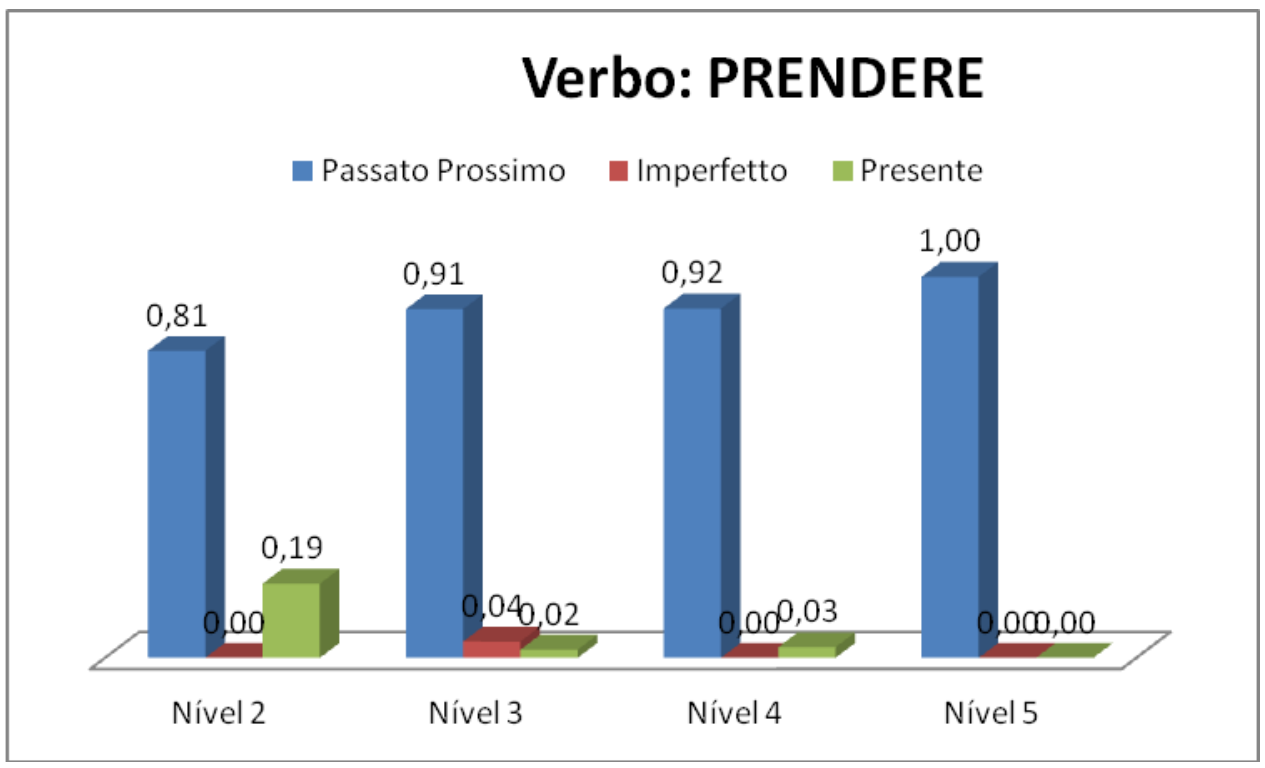

Tabela 18 - Desvio padrão do verbo prendere

\begin{tabular}{|c|c|c|c|c|c|c|c|c|c|c|c|}
\hline \multicolumn{12}{|c|}{ DESVIO PADRÃO } \\
\hline \multicolumn{3}{|c|}{ Nível 2} & \multicolumn{3}{|c|}{ Nível 3} & \multicolumn{3}{|c|}{ Nível 4} & \multicolumn{3}{|c|}{ Nível 5} \\
\hline P.P. & IMP. & PRES. & P.P. & IMP. & PRES. & P.P. & IMP. & PRES. & P.P. & IMP. & PRES. \\
\hline 0,40 & 0 & 0,40 & 0,28 & 0,20 & 0,15 & 0,28 & 0 & 0,17 & 0 & 0 & 0 \\
\hline
\end{tabular}

As características do verbo prendere [pegar] são - duração, + dinamicidade, + telicidade. A sua utilização no passato prossimo, tempo também adotado no texto 
original, foi crescente e notavelmente superior ao uso do tempo presente, fato ocorrido com maior expressividade no nível II, ainda que não ultrapassasse a utilização da marca perfectiva. Assim, como os verbos partire e arrivare, já no segundo nível do curso de italiano, os alunos associaram o verbo ao tempo que haviam recém aprendido, o passato prossimo.

\section{Gráfico 28 - Verbo mettermi}

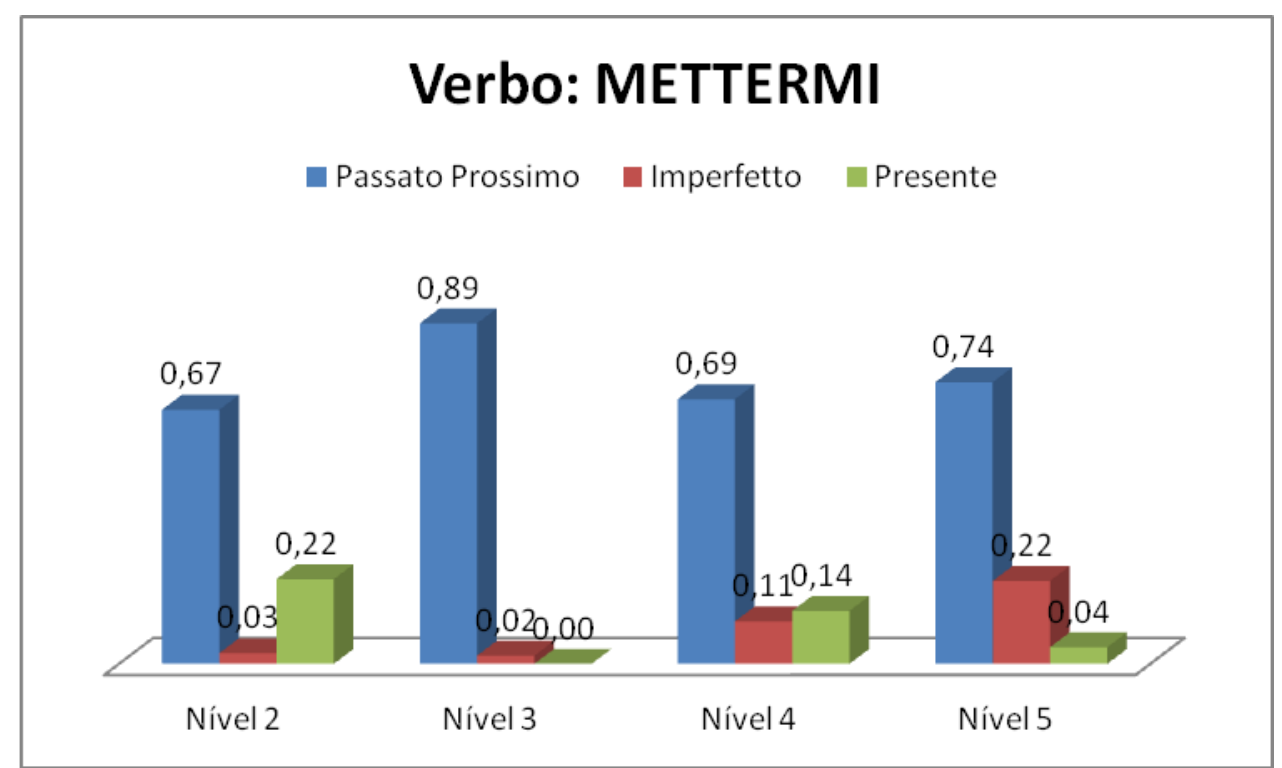

Tabela 19 - Desvio padrão do verbo mettermi

\begin{tabular}{|c|c|c|c|c|c|c|c|c|c|c|c|}
\hline \multicolumn{12}{|c|}{ DESVIO PADRÃO } \\
\hline \multicolumn{3}{|c|}{ Nível 2} & \multicolumn{3}{|c|}{ Nível 3} & \multicolumn{3}{|c|}{ Nível 4} & \multicolumn{3}{|c|}{ Nível 5} \\
\hline P.P. & IMP. & PRES. & P.P. & IMP. & PRES. & P.P. & IMP. & PRES. & P.P. & IMP. & PRES. \\
\hline 0,48 & 0,17 & 0,42 & 0,31 & 0,15 & 0 & 0,47 & 0,32 & 0,35 & 0,45 & 0,42 & 0,21 \\
\hline
\end{tabular}

O verbo mettermi [colocar-me], caracterizado pelos traços de - duração, + dinamicidade e + telicidade, apresentou a utilização semelhante ao verbo riuscire, no que se refere ao uso do passato prossimo e do presente. As semelhanças se relacionam ao alto uso desse verbo por aluno no passato prossimo no nível II, número que cresceu no nível seguinte, diminuiu no nível IV e apresentou um aumento no último nível do teste. O tempo presente, por sua vez, apresentou maior utilização pelos aprendizes no 
nível II do que nos níveis seguintes. É interessante considerar que o aumento do número de uso do verbo mettermi no imperfetto provocou a queda do uso do passato prossimo no nível IV e, no nível $\mathrm{V}$, os gráficos apresentam a queda do uso do presente e o aumento das duas marcas, a perfectiva e a imperfectiva.

\section{Gráfico 29 - Verbo capirsi}

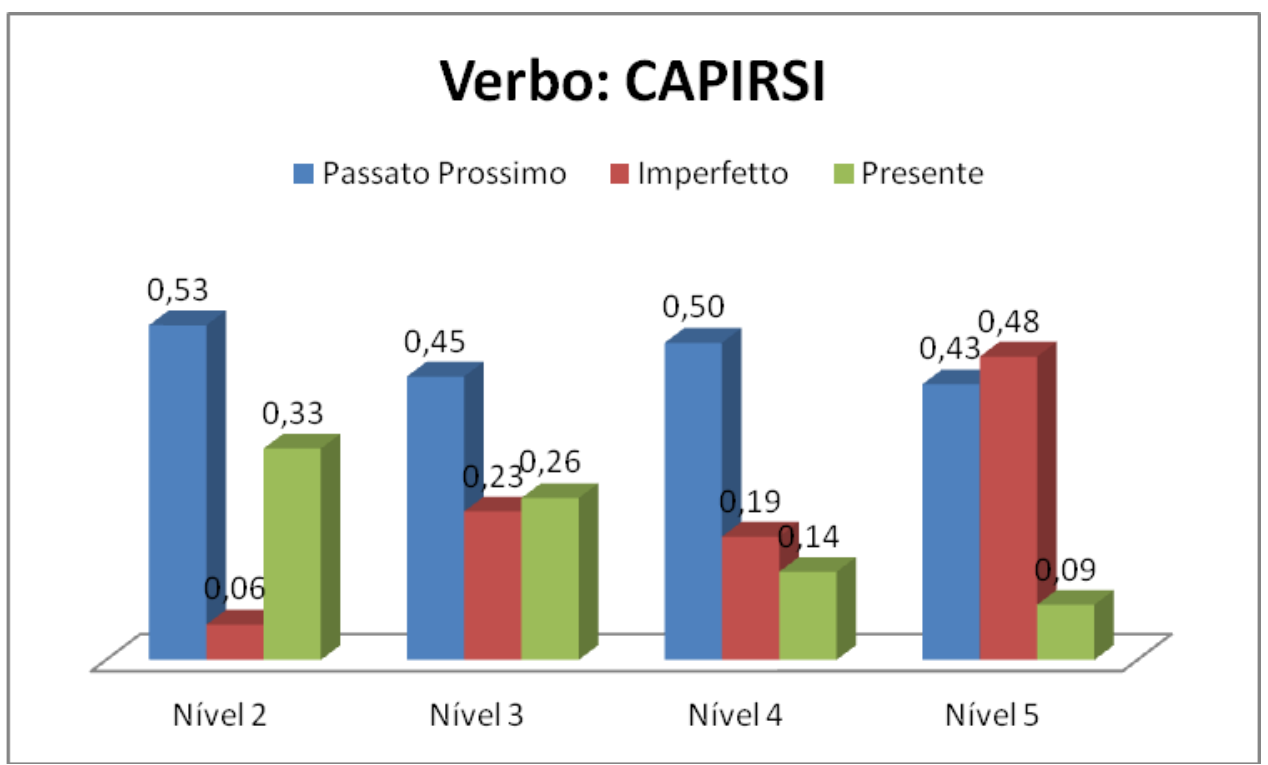

Tabela 20 - Desvio padrão do verbo capirsi

\begin{tabular}{|c|c|c|c|c|c|c|c|c|c|c|c|}
\hline \multicolumn{12}{|c|}{ DESVIO PADRÃO } \\
\hline \multicolumn{3}{|c|}{ Nível 2} & \multicolumn{3}{|c|}{ Nível 3} & \multicolumn{3}{|c|}{ Nível 4} & \multicolumn{3}{|c|}{ Nível 5} \\
\hline P.P. & IMP. & PRES. & P.P. & IMP. & PRES. & P.P. & IMP. & PRES. & P.P. & IMP. & PRES. \\
\hline 0,51 & 0,23 & 0,48 & 0,50 & 0,43 & 0,44 & 0,51 & 0,40 & 0,35 & 0,51 & 0,51 & 0,29 \\
\hline
\end{tabular}

O verbo capirsi [entender-se] possui os traços de - duração, + dinamicidade, + telicidade. No texto original, ele foi utilizado no tempo imperfetto “...io parlavo in spagnolo e lui in portoghese e ci capivamo, non so come..." [...eu falava em espanhol e ele em português e nos entendíamos, não sei como...].

Por meio dos gráficos podemos observar que o uso do tempo presente, embora tenha sido mais recorrente no nível II, ainda apareceu nos níveis seguintes. Apesar 
disso, o uso desse verbo por aluno no passato prossimo superou todos os outros usos nos níveis II, III e IV.

No nível V, porém, a marca imperfectiva superou a marca perfectiva, apesar de não observarmos índices muito distantes. A associação desse verbo ao tempo imperfetto é verificada nos gráficos com poucas ocorrências no nível II, o crescimento delas no nível seguinte, índice que diminuiu no nível IV e aumentou, conforme já vimos, no nível V.

\section{Gráfico 30 - Verbo trovare}

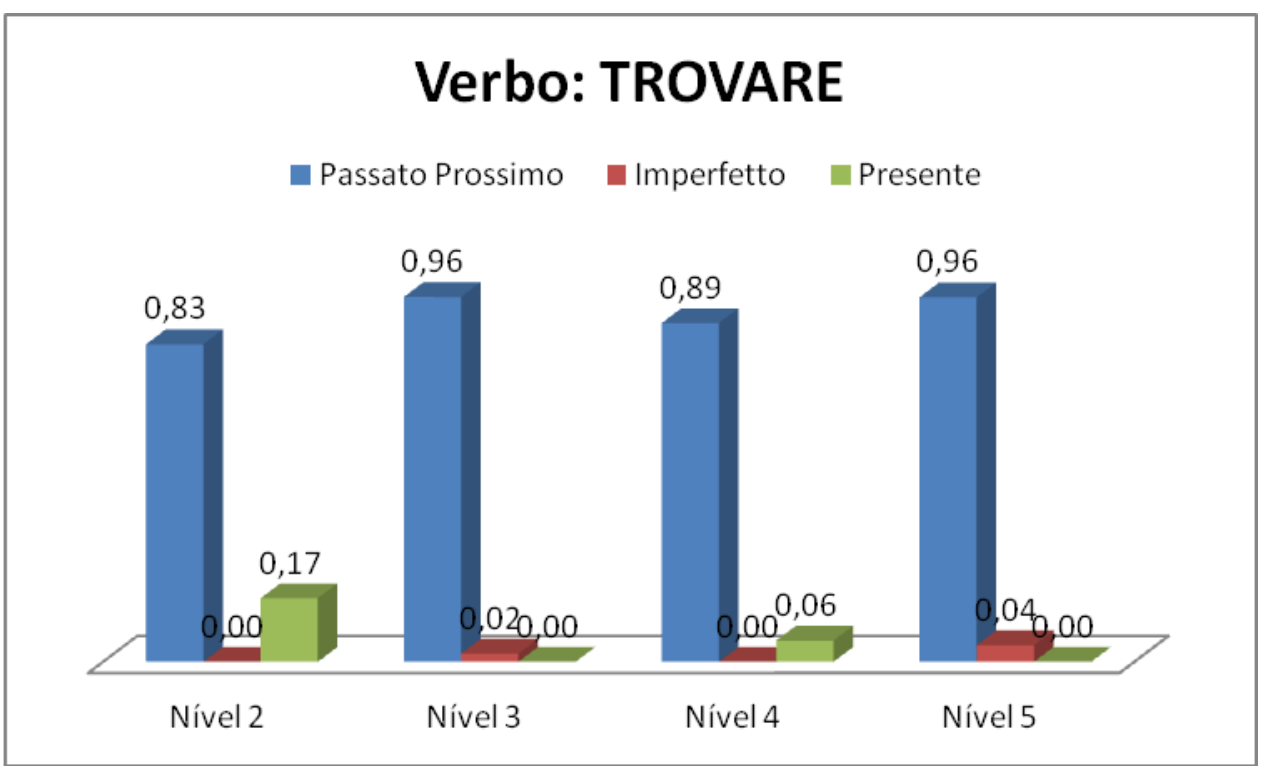

Tabela 21 - Desvio padrão do verbo trovare

\begin{tabular}{|c|c|c|c|c|c|c|c|c|c|c|c|}
\hline \multicolumn{12}{|c|}{ DESVIO PADRÃO } \\
\hline \multicolumn{3}{|c|}{ Nível 2} & \multicolumn{3}{|c|}{ Nível 3} & \multicolumn{3}{|c|}{ Nível 4} & \multicolumn{3}{|c|}{ Nível 5} \\
\hline P.P. & IMP. & PRES. & P.P. & IMP. & PRES. & P.P. & IMP. & PRES. & P.P. & IMP. & PRES. \\
\hline 0,38 & 0 & 0,38 & 0,20 & 0,15 & 0 & 0,32 & 0 & 0,23 & 0,21 & 0,21 & 0 \\
\hline
\end{tabular}

O verbo trovare [encontrar] é marcado pelos traços de - duração, + dinamicidade, + telicidade e o seu uso foi, na maior parte, realizado no passato prossimo. Semelhante ao observado nos verbos anteriores, a maior frequência de uso no 
tempo presente ocorreu no nível II do curso de língua, o que não se observou nos níveis III e V, mas apareceu em baixo índice no nível IV.

Cabe lembrar que o verbo trovare também compareceu nas produções escritas espontâneas dos aprendizes. Entretanto, apesar da sua grande recorrência no passato prossimo já no nível II da língua $(0,53)$, o uso nesse tempo superou o presente apenas no nível III em que obtivemos 0,45 de uso por aluno contra 0,13 desse uso no presente. Nos outros níveis, porém, os gráficos demonstram sempre o maior índice de usos no tempo presente, ainda que o uso no passato prossimo também tenha sido relevante.

Gráfico 31- Verbo visitare

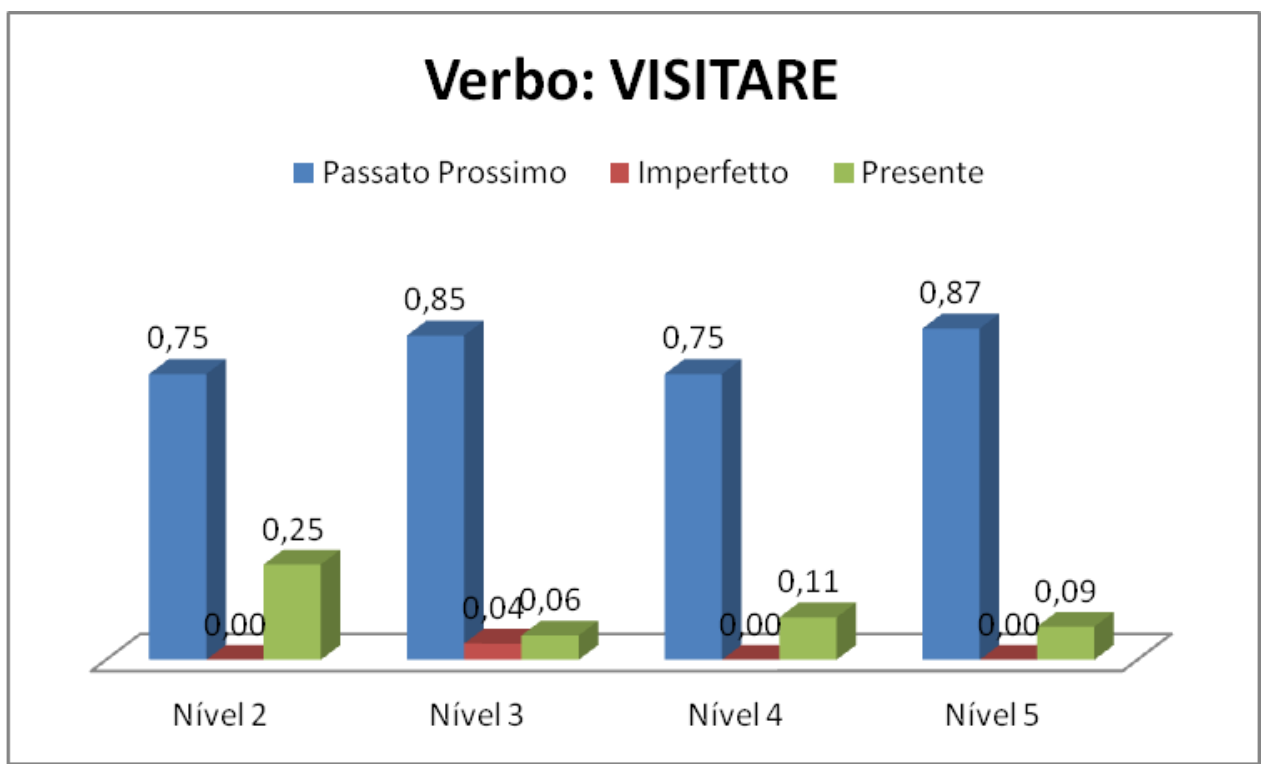

Tabela 22 - Desvio padrão do verbo visitare

\begin{tabular}{|c|c|c|c|c|c|c|c|c|c|c|c|}
\hline \multicolumn{12}{|c|}{ DESVIO PADRÃO } \\
\hline \multicolumn{3}{|c|}{ Nível 2} & \multicolumn{3}{|c|}{ Nível 3} & \multicolumn{3}{|c|}{ Nível 4} & \multicolumn{3}{|c|}{ Nível 5} \\
\hline P.P. & IMP. & PRES. & P.P. & IMP. & PRES. & P.P. & IMP. & PRES. & P.P. & IMP. & PRES. \\
\hline 0,44 & 0 & 0,44 & 0,36 & 0,20 & 0,25 & 0,44 & 0 & 0,32 & 0,34 & 0 & 0,29 \\
\hline
\end{tabular}

O verbo visitare [visitar] também é um verbo télico, entretanto, apresenta os traços de - duração, + dinamicidade e + telicidade. Por meio dos gráficos podemos notar a utilização do imperfetto apenas no nível III do curso, apesar de ser pouco 
relevante se comparado ao uso do passato prossimo, tempo que superou os outros usos em todos os níveis. O tempo presente, seguindo a tendência que observamos até o momento, apresentou maior índice no nível II, seguido pela queda no nível III, pelo aumento do seu uso no nível IV e a sua diminuição no nível V.

\section{Gráfico 32- Verbo essere}

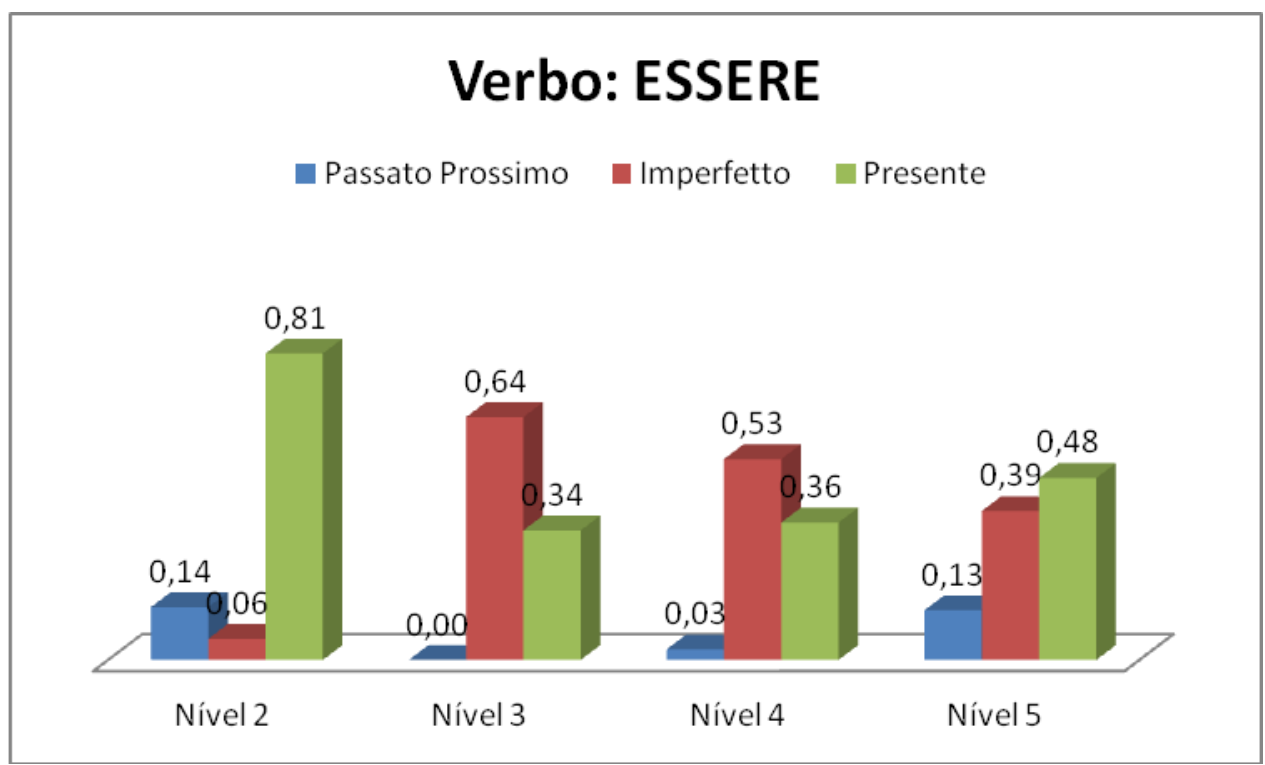

Tabela 23 - Desvio padrão do verbo essere

\begin{tabular}{|c|c|c|c|c|c|c|c|c|c|c|c|}
\hline \multicolumn{12}{|c|}{ DESVIO PADRÃO } \\
\hline \multicolumn{3}{|c|}{ Nível 2} & \multicolumn{3}{|c|}{ Nível 3} & \multicolumn{3}{|c|}{ Nível 4} & \multicolumn{3}{|c|}{ Nível 5} \\
\hline P.P. & IMP. & PRES. & P.P. & IMP. & PRES. & P.P. & IMP. & PRES. & P.P. & IMP. & PRES. \\
\hline 0,35 & 0,23 & 0,40 & 0 & 0,49 & 0,48 & 0,17 & 0,51 & 0,49 & 0,34 & 0,50 & 0,51 \\
\hline
\end{tabular}

O verbo essere [ser] apresenta os traços de + duração, - dinamicidade e telicidade. No texto original foi utilizado da seguinte maneira "La vita notturna a Copacabana era un po' dispersiva" [A vida noturna em Copacabana era um pouco dispersiva].

Sabemos que o verbo, a partir do ponto de referência estabelecido, nesse caso, o passado “nell'estate del 2004" [no verão de 2004], deveria ser conjugado no passado e, mais especificamente, em se tratando de uma descrição, utilizando-se do imperfetto. 
Entretanto, como nos mostram os gráficos, houve maior recorrência de uso no tempo presente tanto no primeiro quanto no último teste. $\mathrm{O}$ uso da marca imperfectiva cresceu no nível III, momento posterior ao aprendizado explícito de tal forma verbal, mas diminuiu nos níveis IV e $\mathrm{V}$ em detrimento do crescimento do uso do tempo presente. Houve algumas associações do verbo atélico à marca perfectiva, ainda que, no texto, não fosse o uso mais adequado.

É interessante relacionar o uso desse verbo na atividade proposta ao mesmo verbo na primeira atividade, aquela de produção escrita livre. Houve maior índice de uso do verbo essere no imperfetto nos níveis III e IV, semelhante ao que ocorreu nos gráficos acima, mas no último nível o uso desse tempo também ultrapassou a utilização do presente, fato não observado na segunda atividade.

\section{Gráfico 33- Verbo preferire}

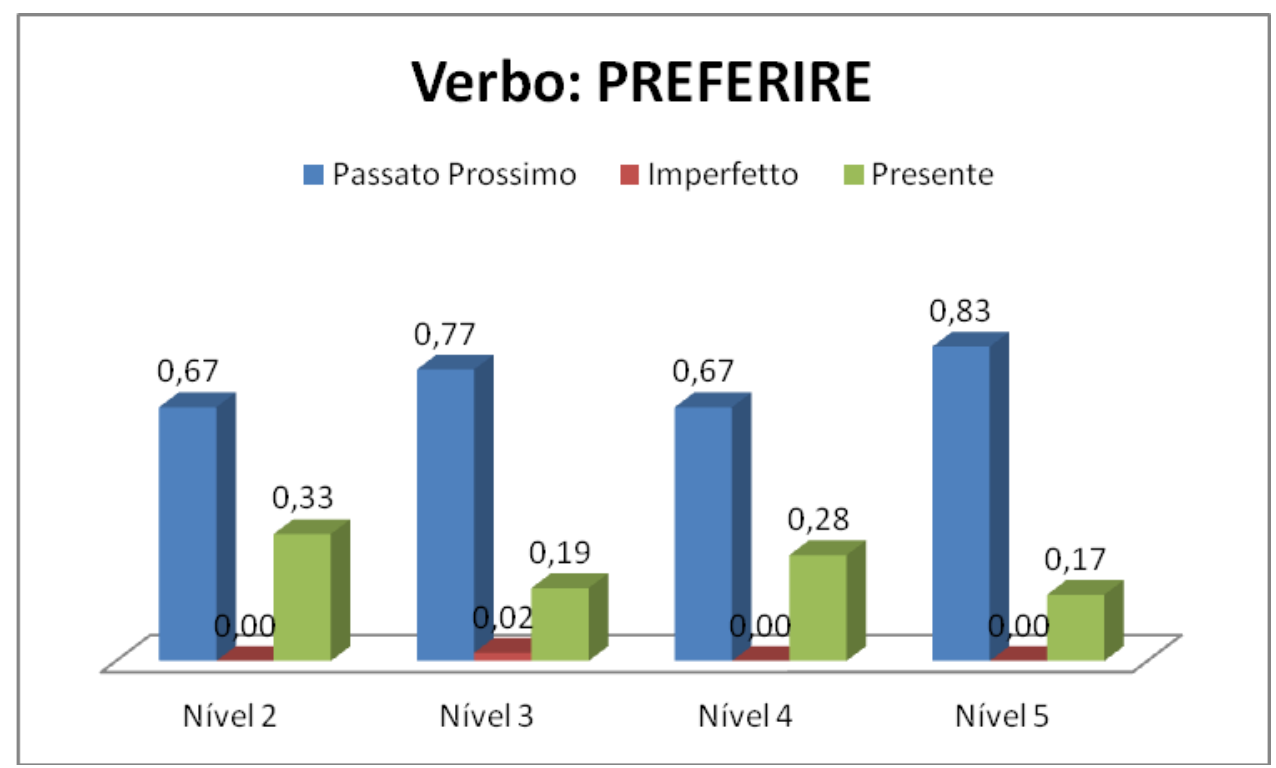

Tabela 24 - Desvio padrão do verbo preferire

\begin{tabular}{|c|c|c|c|c|c|c|c|c|c|c|c|}
\hline \multicolumn{12}{|c|}{ DESVIO PADRÃO } \\
\hline \multicolumn{3}{|c|}{ Nível 2} & \multicolumn{3}{|c|}{ Nível 3} & \multicolumn{3}{|c|}{ Nível 4} & \multicolumn{3}{|c|}{ Nível 5} \\
\hline P.P. & IMP. & PRES. & P.P. & IMP. & PRES. & P.P. & IMP. & PRES. & P.P. & IMP. & PRES. \\
\hline 0,48 & 0 & 0,48 & 0,43 & 0,15 & 0,40 & 0,48 & 0 & 0,45 & 0,39 & 0 & 0,39 \\
\hline
\end{tabular}


O verbo preferire [preferir] assume os traços de + duração, - dinamicidade e telicidade. Conforme podemos observar nos gráficos, houve grande escolha pelo tempo passato prossimo, que ultrapassou as outras conjugações no que concerne ao seu uso. Entretanto, vale considerar que se em alguns verbos como partire, arrivare, prendere e trovare, o uso do presente quase não existiu nos níveis III, IV e V, houve ocorrências do tempo presente com o verbo preferire em todos os níveis. Já no imperfetto, o único índice encontrado ocorreu no nível III e foi muito baixo.

\section{Gráfico 34 - Verbo durare}

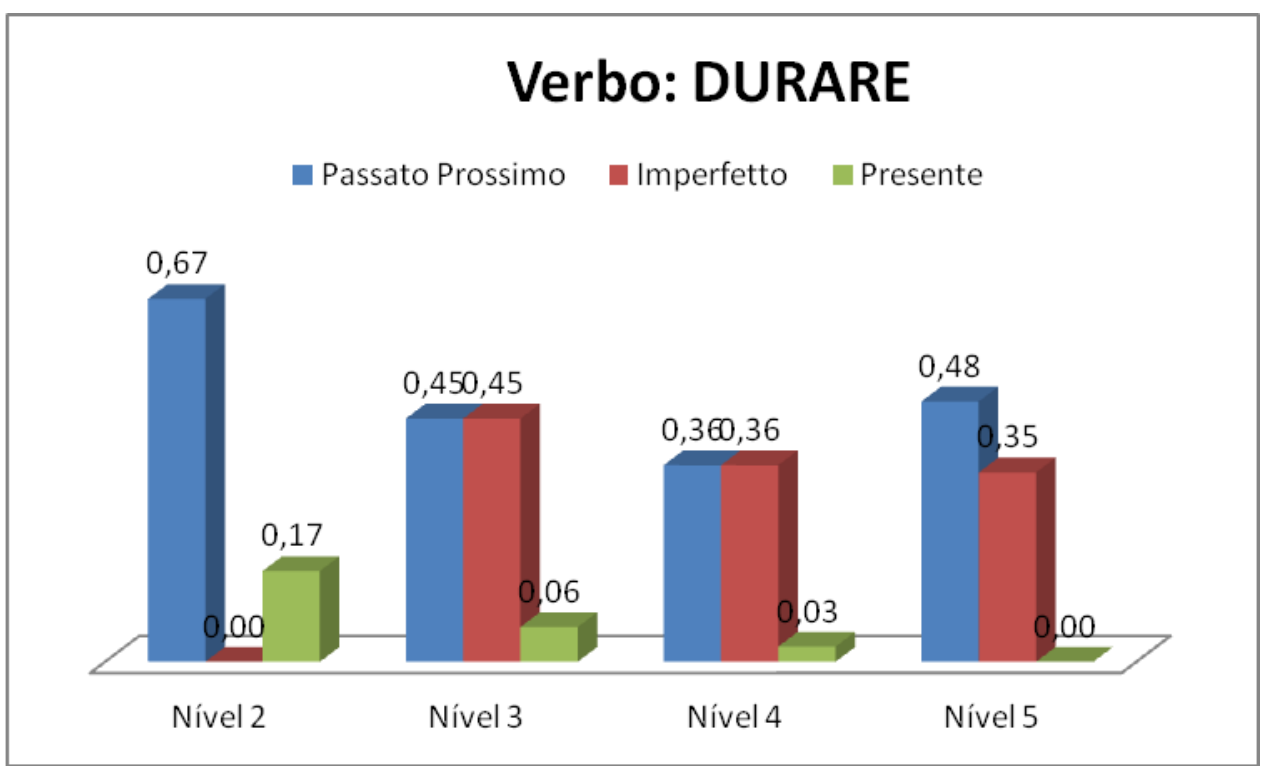

Tabela 25 - Desvio padrão do verbo durare

\begin{tabular}{|c|c|c|c|c|c|c|c|c|c|c|c|}
\hline \multicolumn{12}{|c|}{ DESVIO PADRÃO } \\
\hline \multicolumn{3}{|c|}{ Nível 2} & \multicolumn{3}{|c|}{ Nível 3} & \multicolumn{3}{|c|}{ Nível 4} & \multicolumn{3}{|c|}{ Nível 5} \\
\hline P.P. & IMP. & PRES. & P.P. & IMP. & PRES. & P.P. & IMP. & PRES. & P.P. & IMP. & PRES. \\
\hline 0,48 & 0 & 0,38 & 0,50 & 0,50 & 0,25 & 0,49 & 0,49 & 0,17 & 0,51 & 0,49 & 0 \\
\hline
\end{tabular}

O verbo durare [durar] possui os traços de + duração, - dinamicidade e telicidade. No texto original, foi conjugado no imperfetto "La seconda serata abbiamo preferito restare in piazza dato che la festa durava tre giorni!" [Na segunda noite preferimos ficar na praça já que a festa durava três dias]. 
Se no nível II, não houve nenhuma ocorrência desse verbo no imperfetto, mas sim no passato prossimo e no presente, nos níveis seguintes o índice nos mostra que não houve muitas utilizações do verbo por aluno no tempo presente, mas, ao contrário, a escolha se deu, sobretudo, entre os tempos passato prossimo e imperfetto que apresentaram os mesmos índices nos níveis III e IV. No último nível do teste, houve associação do verbo à marca perfectiva.

\section{Gráfico 35 - Verbo sentirsi}

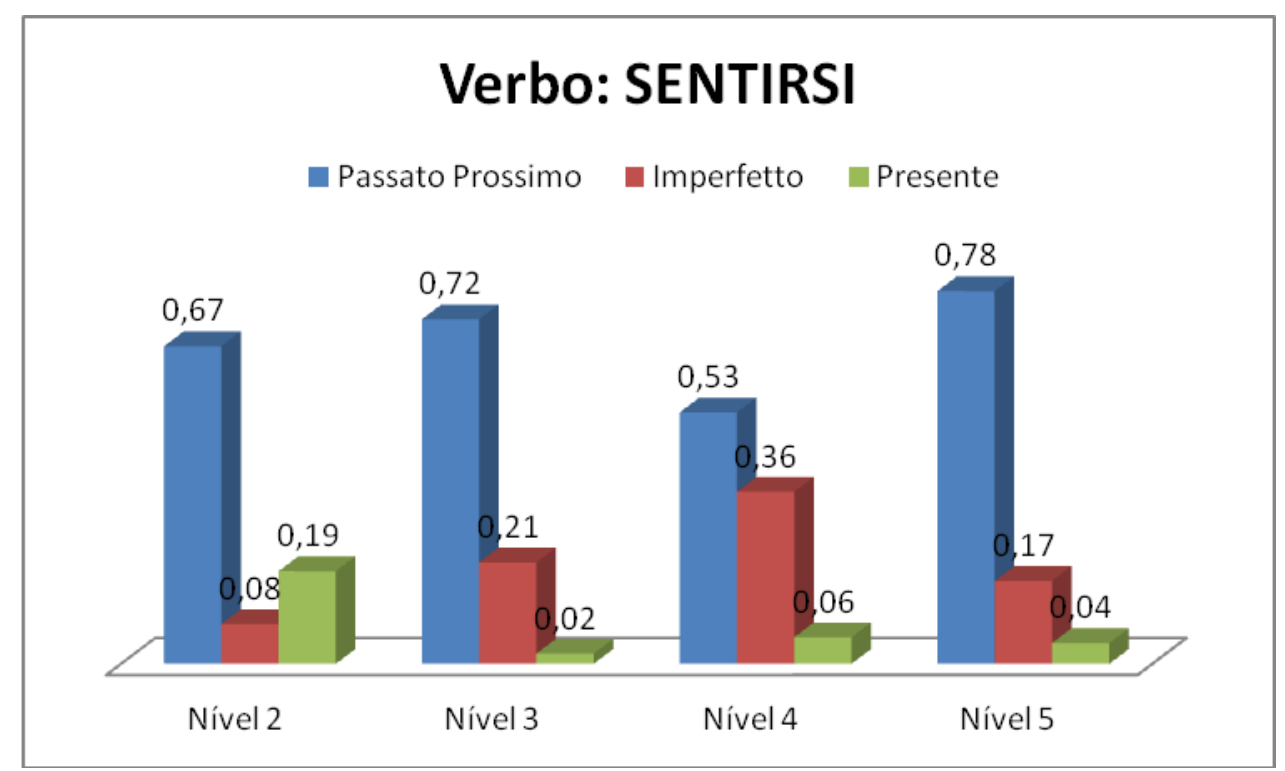

Tabela 26 - Desvio padrão do verbo sentirsi

\begin{tabular}{|c|c|c|c|c|c|c|c|c|c|c|c|}
\hline \multicolumn{12}{|c|}{ DESVIO PADRÃO } \\
\hline \multicolumn{3}{|c|}{ Nível 2} & \multicolumn{3}{|c|}{ Nível 3} & \multicolumn{3}{|c|}{ Nível 4} & \multicolumn{3}{|c|}{ Nível 5} \\
\hline P.P. & IMP. & PRES. & P.P. & IMP. & \begin{tabular}{|l} 
PRES. \\
\end{tabular} & P.P. & IMP. & PRES. & P.P. & IMP. & PRES. \\
\hline 0,48 & 0,28 & 0,40 & 0,45 & 0,41 & 0,15 & 0,51 & 0,49 & 0,23 & 0,42 & 0,39 & 0,21 \\
\hline
\end{tabular}

Os traços do verbo sentirsi [sentir-se] são de + duração, - dinamicidade, telicidade. Houve alto índice de utilização desse verbo no passato prossimo já no nível 2, ou seja, em seguida à sua instrução formal, fato que permaneceu em todos os níveis seguintes. Cabe considerar que no texto original o verbo também foi associado à marca perfectiva "Mentre l'aereo sorvolava la città, mi sono sentita molto piccola" [Enquanto 
o avião sobrevoava a cidade, senti-me muito pequena]. Observemos que a construção da primeira oração com o advérbio mentre [enquanto] poderia levar ao uso da segunda no passato prossimo, conforme os exemplos encontrados no material didático adotado pelo curso, sobretudo, no Linea diretta 1B na lição 4, estudada somente no final do nível III e, ainda no Linea diretta 2 lição 1, abordada no início do quinto semestre. Verificamos o crescimento do uso do imperfetto no nível seguinte a essa retomada de usos do tempo imperfetto pelo material didático. Ainda assim, o uso do passato prossimo, conforme já dissemos, se sobrepôs à marca imperfectiva.

\section{Gráfico 36 - Verbo esserci}

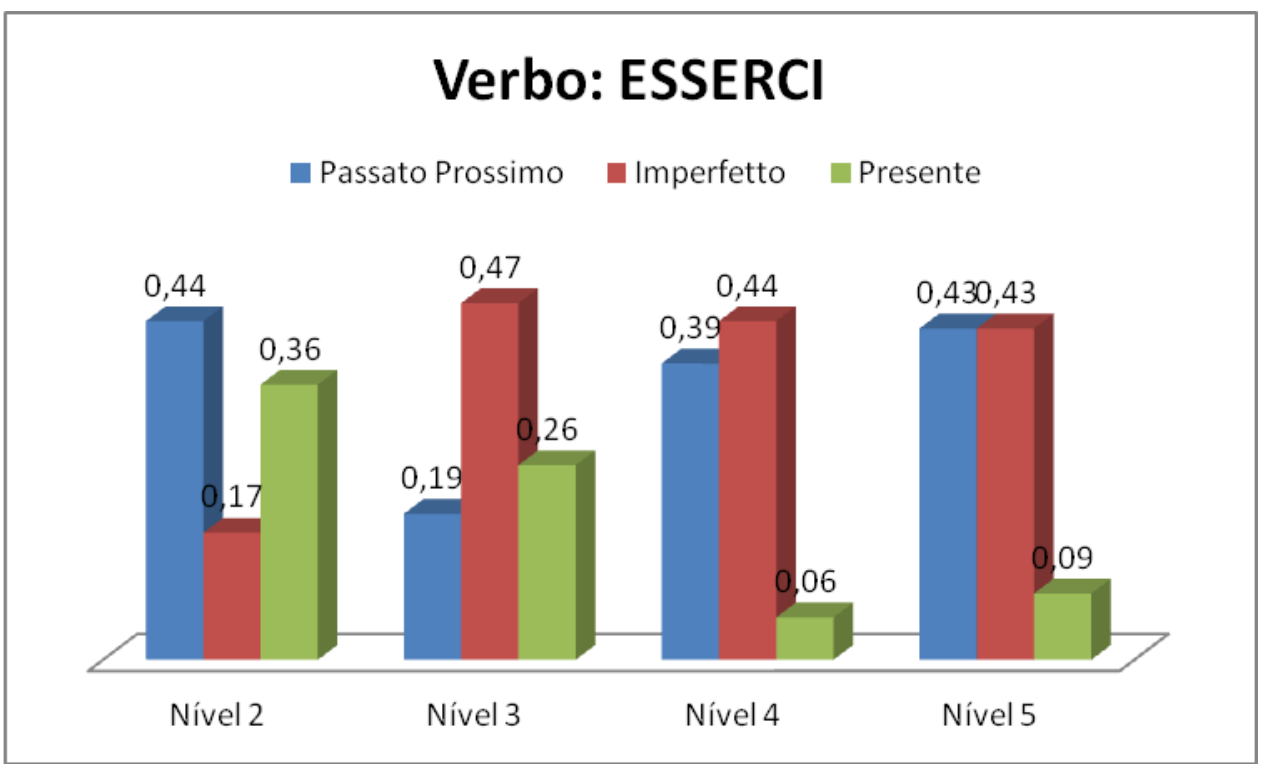

Tabela 27 - Desvio padrão do verbo esserci

\begin{tabular}{|c|c|c|c|c|c|c|c|c|c|c|c|}
\hline \multicolumn{12}{|c|}{ DESVIO PADRÃO } \\
\hline \multicolumn{3}{|c|}{ Nível 2} & \multicolumn{3}{|c|}{ Nível 3} & \multicolumn{3}{|c|}{ Nível 4} & \multicolumn{3}{|c|}{ Nível 5} \\
\hline P.P. & IMP. & PRES. & P.P. & IMP. & PRES. & P.P. & IMP. & PRES. & P.P. & IMP. & PRES. \\
\hline 0,50 & 0,38 & 0,49 & 0,40 & 0,50 & 0,44 & 0,49 & 0,50 & 0,23 & 0,51 & 0,51 & 0,29 \\
\hline
\end{tabular}

Na produção textual original, o verbo esserci (haver), que assume os traços de + duração, - dinamicidade e - telicidade, foi utilizado no passato prossimo "Avevo prenotato un ostello a Copacabana e c'è stato um piccolo problema" [Tinha reservado 
um albergue em Copacabana e houve um pequeno problema]. Podemos observar nos gráficos que, no nível II, houve ocorrência do verbo no imperfetto, ainda que os alunos não tivessem sido expostos à instrução explícita dessa forma, porém o maior uso por aluno se deu no passato prossimo e no presente. No nível III, diminuíram os usos do presente e do passato prossimo e cresceu a média de uso por aluno desse verbo no imperfetto. No nível IV, apesar de não ter superado o uso do imperfetto, a marca perfectiva cresceu consideravelmente até que, no nível $\mathrm{V}$, encontramos os mesmos índices para as marcas pefectiva e imperfectiva. Pode ser que em seguida ao momento do aprendizado formal do passato prossimo, os aprendizes tenham sido levados a utilizá-la na composição escrita, entretanto, posterior a esse momento, seguido também pelo ensino explícito do imperfetto, esse último tempo tenha sido escolhido pelos alunos, considerando também os traços já citados anteriormente, ou seja, que os aprendizes tenham associado o verbo atélico de traço + duração ao uso de um tempo que também expressasse duratividade. Podemos notar que nos níveis seguintes, IV e V, muitos dos usos do mesmo verbo foram associados à marca perfectiva, mostrando que os aprendizes começam a ser capazes de associar o verbo não às marcas de perfectividade e imperfectividade seguindo não as características do próprio verbo, mas observando os efeitos que desejam produzir no discurso. 


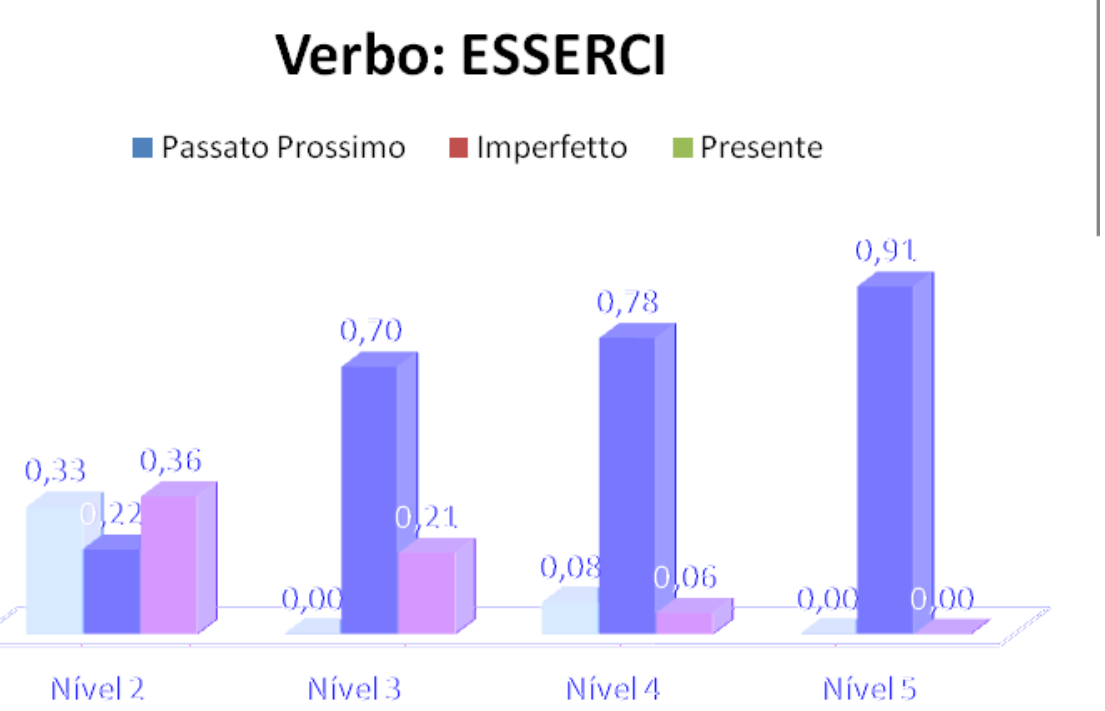

Tabela 28 - Desvio padrão do verbo esserci II

\begin{tabular}{|c|c|c|c|c|c|c|c|c|c|c|c|}
\hline \multicolumn{12}{|c|}{ DESVIO PADRÃO } \\
\hline \multicolumn{3}{|c|}{ Nível 2} & \multicolumn{3}{|c|}{ Nível 3} & \multicolumn{3}{|c|}{ Nível 4} & \multicolumn{3}{|c|}{ Nível 5} \\
\hline P.P. & IMP. & PRES. & P.P. & IMP. & PRES. & P.P. & IMP. & PRES. & P.P. & IMP. & PRES. \\
\hline 0,48 & 0,42 & 0,49 & 0 & 0,46 & 0,41 & 0,28 & 0,42 & 0,23 & 0 & 0,29 & 0 \\
\hline
\end{tabular}

Conforme já vimos anteriormente, o verbo esserci [haver] apresenta os traços de + duração, - dinamicidade e - telicidade. Na produção original o verbo foi escrito no imperfetto "c'era una festa in piazza proprio davanti l'ostello" [havia uma festa na praça exatamente em frente ao albergue].

No nível 2, podemos observar que os índices de usos no presente, no passato prossimo e no imperfetto são próximos, um fator que poderia ter levado a essas ocorrências é que os aprendizes foram submetidos durante 1 semestre ao aprendizado de verbos no tempo presente e no momento da realização do teste haviam sido expostos explicitamente ao uso do passato prossimo, porém, devido à necessidade de exprimirem uma ação de duração no passado, houve algumas tentativas de utilização do imperfetto. 
Porém, nos níveis seguintes, o uso do imperfetto cresceu, ao ponto de ser o único a ser usado no nível V. Cabe observar que o presente também apareceu nas produções do nível III e diminuiu consideravelmente no nível IV, semestres que se distanciavam do ensino explícito do tempo presente.

É interessante considerar que na atividade de escrita do filme a que haviam assistido, o verbo esserci não apareceu no passato prossimo no nível II e uso do presente se sobrepôs notavelmente ao uso do imperfetto. No nível III, o uso do imperfetto superou a utilização do presente, mas a distância não foi tão grande. No nível seguinte, o uso do presente voltou a superar o uso do imperfetto e, no último nível, as recorrências nos dois tempos foram igualadas.

\section{Gráfico 38 - Verbo provare}

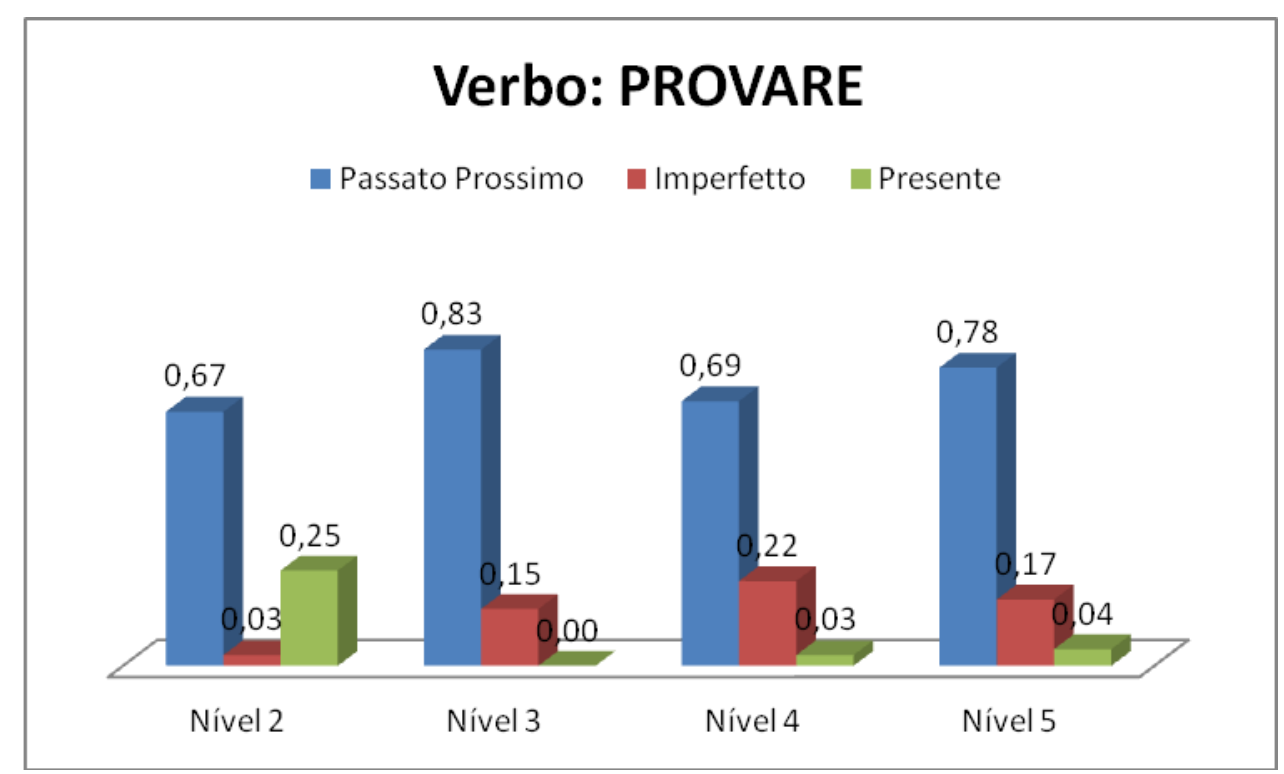

Tabela 29 - Desvio padrão do verbo trovare

\begin{tabular}{|c|c|c|c|c|c|c|c|c|c|c|c|}
\hline \multicolumn{12}{|c|}{ DESVIO PADRÃO } \\
\hline \multicolumn{3}{|c|}{ Nível 2} & \multicolumn{3}{|c|}{ Nível 3} & \multicolumn{3}{|c|}{ Nível 4} & \multicolumn{3}{|c|}{ Nível 5} \\
\hline P.P. & IMP. & PRES. & P.P. & IMP. & PRES. & P.P. & IMP. & PRES. & P.P. & IMP. & PRES. \\
\hline 0,48 & 0,17 & 0,44 & 0,38 & 0,36 & 0 & 0,46 & 0,42 & 0,16 & 0,39 & 0,39 & 0 \\
\hline
\end{tabular}


O verbo provare [vivenciar] possui os seguintes traços: + duração, + dinamicidade e - telicidade. “Ho provato un po' di inquietudine” [vivenciei um pouco de inquietude]. As maiores ocorrências desses tempos foram no passato prossimo em todos os níveis. Como já notamos anteriormente, o presente apareceu, principalmente, no nível II do curso de língua. É interessante também considerar que houve um pequeno crescimento do uso desse verbo no tempo imperfetto dos níveis II até o IV, mas ainda que fosse um verbo atélico foi associado à marca perfectiva.

Gráfico 39 - Verbo parlare

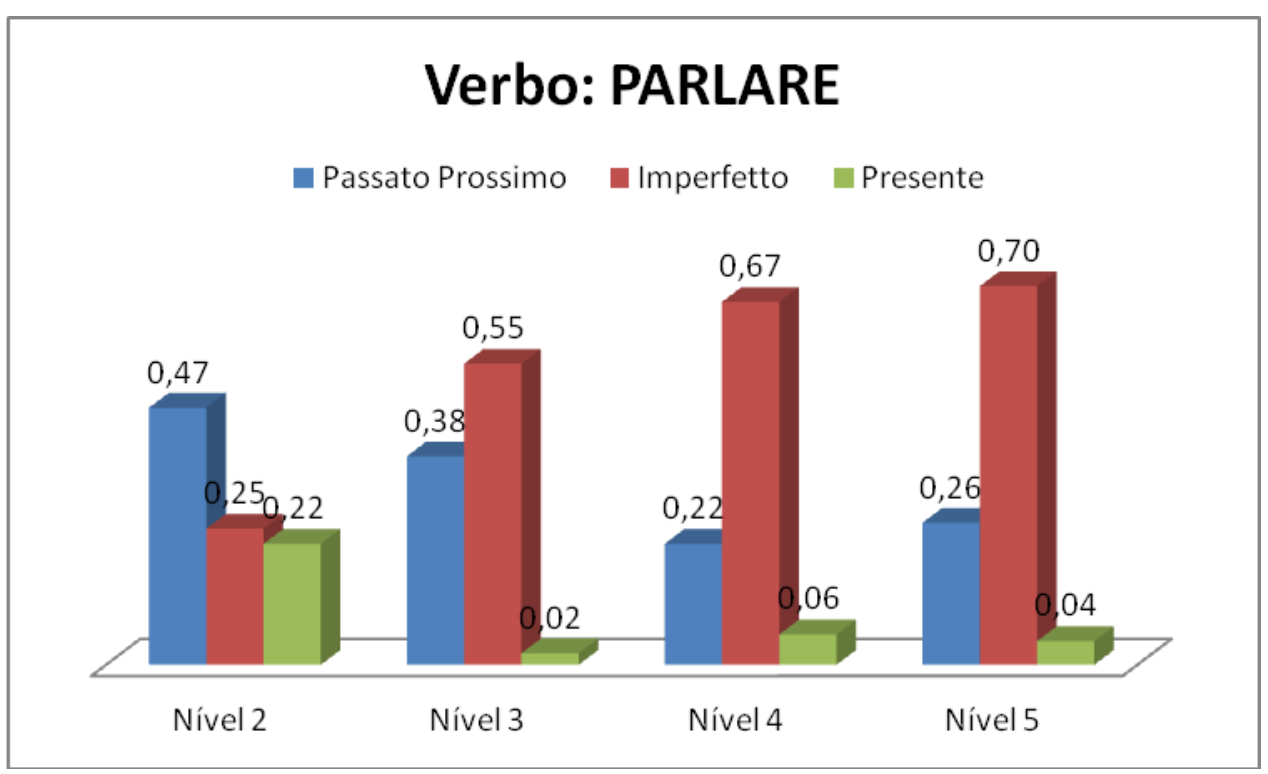

Tabela 30 - Desvio padrão do verbo parlare

\begin{tabular}{|c|c|c|c|c|c|c|c|c|c|c|c|}
\hline \multicolumn{12}{|c|}{ DESVIO PADRÃO } \\
\hline \multicolumn{3}{|c|}{ Nível 2} & \multicolumn{3}{|c|}{ Nível 3} & \multicolumn{3}{|c|}{ Nível 4} & \multicolumn{3}{|c|}{ Nível 5} \\
\hline P.P. & IMP. & PRES. & P.P. & IMP. & PRES. & P.P. & IMP. & PRES. & P.P. & IMP. & PRES. \\
\hline 0,51 & 0,44 & 0,42 & 0,49 & 0,50 & 0,15 & 0,42 & 0,48 & 0,23 & 0,45 & 0,47 & 0,21 \\
\hline
\end{tabular}

O verbo parlare [falar] apresenta os traços de + duração, + dinamicidade e telicidade. Na produção escrita original a autora utilizou o imperfetto "...parlavo in spagnolo e lui in portoghese" [...falava em espanhol e ele em português]. 
No primeiro nível do teste, observamos um alto índice do passato prossimo, tempo recentemente abordado explicitamente, mas também notamos que o uso do imperfetto superou o uso do presente, ainda que a estrutura não tivesse sido abordada no curso. A partir do nível III, o uso do imperfetto cresceu. É necessário considerar que ainda nesse nível, houve um alto índice de utilização por parte dos alunos da marca perfectiva, índice que se reduziu no nível IV e aumentou um pouco no nível $\mathrm{V}$. Na verdade, conforme podemos observar, as diferenças mais consideráveis de utilização dos dois tempos do passado, ocorreram, sobretudo, nos níveis IV e V.

Gráfico 40 - Verbo sorvolare

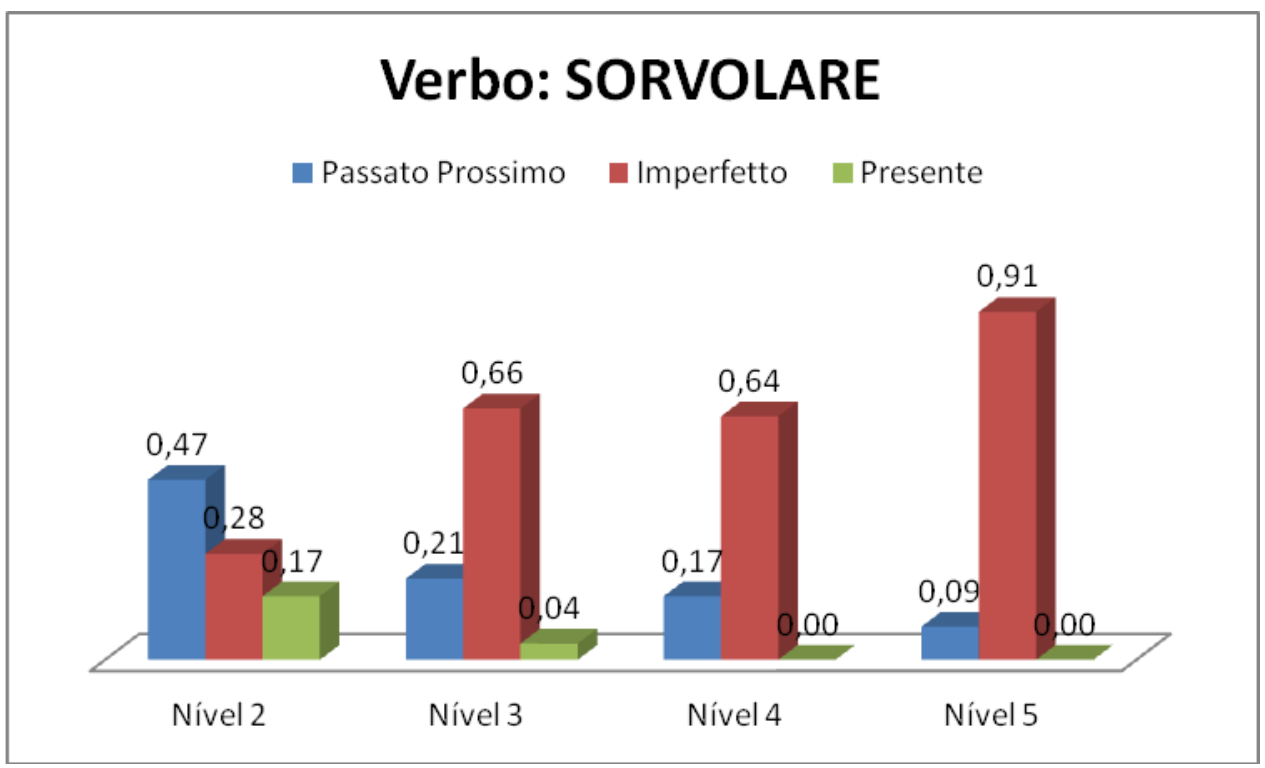

Tabela 31 - Desvio padrão do verbo sorvolare

\begin{tabular}{|c|c|c|c|c|c|c|c|c|c|c|c|}
\hline \multicolumn{12}{|c|}{ DESVIO PADRÃO } \\
\hline \multicolumn{3}{|c|}{ Nível 2} & \multicolumn{3}{|c|}{ Nível 3} & \multicolumn{3}{|c|}{ Nível 4} & \multicolumn{3}{|c|}{ Nível 5} \\
\hline P.P. & IMP. & PRES. & P.P. & IMP. & PRES. & P.P. & IMP. & PRES. & P.P. & IMP. & PRES. \\
\hline 0,51 & 0,45 & 0,38 & 0,41 & 0,48 & 0,20 & 0,38 & 0,49 & 0 & 0,29 & 0,29 & 0 \\
\hline
\end{tabular}

Apresentando os traços de + duração, + dinamicidade e - telicidade, o verbo sorvolare [sobrevoar] utilizado a partir do advérbio mentre [enquanto] poderia estimular os alunos a utilizarem o imperfetto, fato ocorrido ainda no nível II, apesar do maior 
índice ter sido o do tempo passato prossimo. A partir do nível III, o uso do imperfetto se sobrepôs notavelmente à marca perfectiva e o tempo presente desapareceu nas composições dos níveis IV e V. A ação, que indicava duratividade no passado, correspondia aos traços do próprio verbo e talvez tenha despertado nos aprendizes a necessidade de utilizar a marca imperfectiva já no primeiro nível do teste, ainda que não tivessem aprendido a estrutura em questão.

\subsubsection{Os resultados do cloze}

O teste, retomando os pressupostos já mencionados, consistia na realização de duas atividades diferentes, cujas explicações já foram dadas; entretanto, cabe retomar que a primeira se baseava na produção escrita livre e, a segunda, era um texto em que os espaços deveriam ser preenchidos com os verbos indicados entre parênteses no tempo considerado adequado pelo aprendiz e os resultados foram um pouco distintos. Discutiremos agora, os dados obtidos na atividade de cloze.

No nível II, conforme pudemos observar nos gráficos, verificou-se o aparecimento frequente da estrutura verbal passato prossimo caracterizando uma situação completamente distinta da primeira atividade. No geral, o uso do tempo presente foi restrito aos verbos atélicos esserci [haver], provare [vivenciar], parlare [falar] e sorvolare [sobrevoar] em que também foram constatadas ocorrências do imperfetto.

Consideramos que dos verbos que estavam conjugados no texto original na forma imperfectiva, somente o esserci [haver], o sorvolare [sobrevoar] e o parlare [falar] apresentaram índices de ocorrência nesse tempo já no nível II, característica que permaneceu também nos outros testes realizados posteriormente. 
No nível seguinte, as flexões na marca imperfectiva aumentaram em todos os espaços que, de fato, apresentavam ações durativas, inacabadas, ilimitadas e estáticas, ainda que tenham aparecido também flexões no passato prossimo. Verificamos que tanto na atividade de produção quanto na de cloze, as marcas perfectivas e imperfectivas foram usadas com mais frequência no terceiro nível do curso.

Os predicados télicos se mantiveram associados, sobretudo, à marca perfectiva, ainda que no contexto se referissem a ações durativas como, por exemplo, o verbo riuscire [conseguir] que obteve um crescimento principalmente nos níveis III e IV, mas não superou o passato prossimo.

O verbo télico capirsi [entender-se] que começou a ser flexionado na marca imperfectiva só superou o uso do perfectivo no último nível, mas ainda assim, não foi um uso exclusivo.

\subsection{Relações entre os resultados obtidos}

Podemos estabelecer algumas relações entre os dois tipos de atividades no formato longitudinal da pesquisa:

- foi verificado o uso do verbo essere [ser], sobretudo, no imperfetto, na produção escrita, apesar de não termos observado grandes diferenças entre ele e o presente no nível V. Todavia, na atividade caracterizada como cloze, o uso do tempo presente é recorrente chegando a suplantar o imperfetto no último nível;

- a atividade de produção provocou maior oscilação entre os tempos verbais durante o processo em que os alunos foram submetidos aos testes, mas no cloze não houve tantas diferenças nesse sentido; 
- todos os verbos de cloze foram conjugados no passato prossimo no nível II, ultrapassando a ocorrência do presente, com exceção do segundo verbo esserci;

- na atividade de produção textual, os alunos do nível II na grande maioria flexionaram o verbo no presente;

- no cloze, os predicados télicos apresentaram a tendência de serem associados à marca perfectiva, ainda que apresentassem no contexto característica durativa;

- o verbo esserci [haver], na primeira atividade apresentou variação no uso entre presente e imperfetto. $\mathrm{Na}$ atividade de preencher espaços, havia a possibilidade de conjugar o verbo duas vezes, conforme dissemos, mas o primeiro que apresentava no contexto uma ação pontual também foi associado, no nível III, ao imperfetto e ao presente. O segundo verbo, porém, que descrevia uma ação durativa e inacabada foi ligado à marca imperfectiva nos níveis III, IV e V;

- não obstante no português brasileiro haja o tempo pretérito imperfeito que apresenta as mesmas situações de uso do imperfetto da língua italiana, não podemos assegurar por meio dos dados obtidos que tal tempo seja utilizado de maneira intensa pelos aprendizes antes da instrução formal;

- no nível IV da língua, a atividade de produção provocou uma grande retomada da flexão dos verbos no presente, mas esse resultado não foi verificado na atividade de cloze em que os aprendizes mantiveram o uso das marcas do passado; 
- na produção do texto, notamos um índice reduzido de verbos télicos associados à marca imperfectiva. $\mathrm{Na}$ verdade, os únicos a serem associados a ela foram os atélicos essere e esserci.

Após fazermos esse elenco dos itens observados, gostaríamos de levantar algumas hipóteses sobre os diferentes resultados encontrados nas duas atividades realizadas pelos alunos que, apesar de consistirem em tarefas distintas, tinham por objetivo checar os mesmo dados. Talvez, no nível II do curso de Italiano no campus, o uso do passato prossimo não tenha sido tão frequente porque as atividades propostas pelo material didático não consistiam no desenvolvimento da habilidade escrita. Apesar de terem sido submetidos à exposição de tal forma verbal, a quantidade maior de usos por aluno foi verificada no teste de preencher lacunas que tem lugar especialmente no caderno de exercícios do aluno. O conhecimento explícito, no caso desta pesquisa, não garantiu que, de fato, o aprendiz utilizasse as estruturas da língua na produção escrita, o que nos leva a pensar que talvez faltem atividades de produção textual que permitam essa prática visto que quando a tarefa foi semelhante às propostas pelo livro didático, $\mathrm{o}$ falante foi capaz de realizá-la. Somente no nível III, as flexões nas marcas do passado cresceram, inclusive, a do imperfetto. No que concerne à distinção entre os predicados télicos e atélicos, pudemos observar que, de fato, os primeiros são associados, principalmente, à marca perfectiva, mas os resultados não são suficientes para concluirmos que os atélicos são relacionados primeiro à marca imperfectiva, pois na atividade de cloze foram verificadas muitas flexões desses verbos no passato prossimo, ainda que já conhecessem os dois tempos ditos do passado.

Os efeitos da instrução explícita a curto prazo são verificados de acordo com o tipo de atividade. No cloze, os efeitos permaneceram ao longo dos três semestres, porém 
na produção livre os efeitos demoraram, em grande parte, um semestre para se estabilizarem e aparecem no texto. A longo prazo, isto é, durante o processo de aquisição, percebemos oscilações no uso dos tempos verbais. Cabe considerar que, nessa atividade, alguns dados nos levaram a notar que o tempo presente volta a fazer parte das produções no nível IV do curso, quando não aparecem atividades que reforcem as estruturas do passado. 


\section{Considerações finais}

Retomando as conclusões parciais feitas durante a análise de dados, apresentada no capítulo anterior, pretendemos relacioná-las agora aos objetivos que direcionaram o nosso trabalho, ou seja, verificar se é evidente o efeito da aprendizagem explícita das estruturas ditas do passado da língua italiana, o passato prossimo e o imperfetto, e observar se existe a tendência de associar as marcas aspectuais à telicidade dos verbos.

Para atingir tais objetivos, o estudo se fundamentou na Hipótese do Aspecto (Aspect Hypothesis) que prevê que no processo de aquisição da L2 o falante, nos estágios iniciais, tenha a tendência de associar os predicados télicos, tanto transformativos quanto resultativos, ao aspecto perfectivo, enquanto os atélicos ao aspecto imperfectivo.

Em se tratando do processo de aquisição, também nos apoiamos nas definições expostas sobre a aprendizagem explícita e implícita cujo traço distintivo se caracteriza, sobretudo, no processamento do input com intenção ou não de encontrar regularidades na língua.

Assim, foram estabelecidas algumas perguntas de pesquisa que nortearam o nosso trabalho: (1) se é possível verificar a introdução de uma estrutura na produção do aprendiz em seguida às instruções explícitas; (2) se podem ser observados usos do tempo imperfetto ainda que a estrutura não tenha sido abordada explicitamente; (3) se o efeito dessas instruções pode ser observado a longo prazo; (4) se as marcas perfectivas e imperfectivas são associadas a predicados télicos e atélicos, respectivamente, nos estágios iniciais. 
Em relação aos efeitos produzidos pela instrução explícita do passato prossimo, observamos que o conhecimento consciente de uma estrutura provocou impacto considerável no seu aparecimento em todos os níveis testados (II, III, IV, V) apenas na atividade de tipo cloze, o que nos levou a formular a hipótese de que, por conta das atividades propostas pelo material didático abordado no curso, que se baseiam frequentemente em preenchimento de espaços com verbos adequados ou ainda tarefas de repetição de diálogos cuja mudança se realiza apenas no verbo, os aprendizes, apesar de possuírem conhecimento explícito, não recorrem a ele quando o tipo de atividade desempenhada é diferente da que estão habituados a realizar. A produção livre exige do aluno de maneira evidente a capacidade de construção total de um texto e, talvez, nesse contexto, as referências temporais fornecidas na introdução não tenham sido suficientes para que o aluno utilizasse a instrução explícita recebida e continuasse a produção textual estabelecendo coerência com o tempo verbal que havia sido estipulado como referência. Nessa tarefa, talvez porque o aprendizado explícito do passato prossimo ainda fosse recente, os alunos recorreram principalmente ao uso da estrutura com a qual haviam trabalhado por mais tempo - o presente - e que era suficiente para que eles estabelecessem a comunicação. Cabe considerar que foram encontradas ocorrências de passato prossimo, mas elas não foram tão expressivas quanto o uso do tempo presente, com exceção do verbo cadere [cair]. Esse resultado pode nos levar a perguntar se é, de fato, necessário permanecer durante um semestre, isto é, 45 horas de curso, promovendo a sistematização de um único tempo verbal, o presente.

$\mathrm{Na}$ atividade de tipo cloze, que iniciava com uma data como momento de referência pretérito, a estrutura do passado emergiu com maior amplitude, levando-nos a pensar o seguinte: 
1. os alunos se concentraram apenas no verbo e não na construção de uma produção textual completa;

2. o tema tratado no texto (a viagem) favoreceu o uso do passato prossimo, talvez por já ter sido abordado no livro didático com o objetivo específico de incentivar o uso desse tempo, causando também uma maior familiaridade com o assunto e com a estrutura adequada para expressá-lo.

Através dos dados obtidos e submetidos à análise, não conseguimos responder à pergunta sobre o uso do imperfetto antes da aprendizagem explícita. Pudemos notar nos gráficos que o uso dessa forma verbal observado em cada aluno, apesar de ter aparecido nas produções, não foi tão saliente quanto o de outras estruturas, impossibilitando-nos de elaborar hipóteses.

No que se refere ao efeito da aprendizagem explícita a longo prazo, os dados nos fizeram concluir que na produção escrita há uma oscilação entre o uso dos tempos verbais, pois eles demonstraram que, de maneira geral, o passato prossimo aparece nos textos dos aprendizes principalmente, nos estágio III e V do curso. No primeiro teste, foi muito frequente o uso do tempo presente, característica também observada no quarto nível da língua. Lembramos que no material didático do estágio $\mathrm{V}$, em que são abordadas as quatro últimas unidade do Linea Diretta $1 B$, não foram propostos nem exercícios de sistematização, produções orais ou escritas que favorecessem o uso do passato prossimo. Porém, os resultados encontrados nos dados referentes à atividade de cloze mostrou que os aprendizes tendem a continuar usando as marcas do passado um ano depois do seu aprendizado explícito.

E por fim, nas questões relativas à telicidade e ao aspecto verbal, verificamos que dos seis verbos télicos, fornecidos para a realização da produção escrita, cinco 
foram usados no nível III da língua, sobretudo, no passato prossimo. No mesmo nível, os verbos atélicos, com exceção do vedere [ver], foram relacionados ou ao presente ou ao imperfetto. Na atividade de preencher os espaços, no segundo nível da língua, todos os aprendizes usaram principalmente o passato prossimo independente da telicidade verbal, com exceção da segunda ocorrência do verbo esserci [haver] apontada com maior uso no presente. Mas, cabe considerar que apesar desse fenômeno, no grupo dos verbos atélicos, ainda que tenha prevalecido o uso do passato prossimo, pudemos notar um maior número de ocorrências do imperfetto do que em relação aos verbos télicos. $\mathrm{O}$ verbo riuscire [conseguir], caracterizado por traços de telicidade, foi utilizado principalmente com a marca perfectiva, apesar de, como mencionados anteriormente, ter sido conjugado no texto original na forma imperfectiva. Percebemos o mesmo fenômeno também com o verbo capirsi [entender-se].

Podemos afirmar que, no contexto da nossa pesquisa, foi observada a tendência de os verbos télicos serem associados à marca perfectiva, mas os resultados alcançados não nos permitem estabelecer que, nos primeiros estágios da aquisição, os verbos atélicos sejam relacionados às marcas imperfectivas, pois somente o verbo essere [ser] apresentou tal característica, já que suas ocorrências no imperfetto foram salientes.

Consideramos que ainda há muitos estudos a serem realizados nesse campo, e esperamos que o nosso trabalho, embora restrito ao aprendizado do passato prossimo e do imperfetto em contexto de instrução formal, possa motivar a continuidade de pesquisas que busquem entender como se dá a aquisição da temporalidade do italiano como L2. 


\section{Referências bibliográficas}

ALANEN, Riikka (1995). Input enhancement and rule presentation in second language acquisition. In: SCHIMIDT, R. W. (ed.). Attention and Awareness in Foreign Language Learning. University of Hawai'i Press, Honolulu, 259-302.

ALMEIDA Filho, José Paes (2005). Linguística aplicada ensino de línguas e comunicação. Pontes editores e ArteLingua, Campinas.

ANDERSEN, Roger e SHIRAI, Yasuhiro (1996). Primacy and aspect in first and second language acquisition: the pidgin/creole connection. In: BHATIA, T.K. e RITCHIE, W. Handbook of second language acquisition, vol. 2, CA: Academic Press, San Diego.

BALBONI, Paolo E. (1994) Didattica dell'italiano a stranieri. Bonacci, Roma. . (2002). Le sfide di Babele.UTET Università, Torino.

BANFI, Emanuele e BERNINI, Giuliano (2003). "Il Verbo". In: GIACALONE RAMAT, Anna (org.) Verso l'italiano. Carocci, Roma.

BENVENISTE, Emile (1976). Problemas de linguística geral. Companhia Editora nacional/EDUSP, São Paulo.

BERNINI, Giuliano e RAMAT, Anna Giacalone (org.) (1990). La temporalità nell'acquisizione di lingue seconde. Franco Angelo, Milão.

BERTINETTO, Pier Marco (1986). Tempo, aspetto, e azione nel verbo italiano. Il sistema dell'indicativo. Accademia della Crusca, Firenze.

BIALYSTOK, Ellen (1979). Explicit and implicit judgements on L2 grammaticality. Language Learning, 29, 81-103.

CHINI, Marina (2005). Che cos'è la linguistica acquisizionale. Carocci, Roma.

CONFORTI, Corrado e CUSIMANO, Linda (1998). Linea Diretta nuovo corso di italiano per principianti 1A. Guerra Edizioni, Perugia.

(1998). Linea Diretta nuovo corso di italiano

per principianti 1B. Guerra Edizioni, Perugia.

(1997). Linea Diretta nuovo corso di italiano

per principianti 2. Guerra Edizioni, Perugia. 
(2005). Linea Diretta nuovo corso di italiano

per principianti Guida per l'insegnante 1B. Guerra Edizioni, Perugia.

DANESI, Marcel (1994). Manuale di tecniche per la didattica delle lingue moderne. Armando Editore, Roma.

DEKEYSER, Robert (2003). Implicit and Explicit Learning. In: DOUGHTY, Catherine J. e LONG, Michael H. (orgs.) The Handbook of Second Language Acquisition. Blackwell, Oxford, p. 313-348.

DIAS, Reinildes (2009). "Critérios de avaliação do livro didático (LD) de língua estrangeira (LE)". In: DIAS, Reinildes e CRISTOVÃO, Vera Lúcia Lopes (org) O livro didático de língua estrangeira: múltiplas perspectivas. Mercado das letras, Campinas, p. 199-234.

DOUGHTY, Catherine (1991). Second Language instruction does make a difference: evidence from an empirical study of SL relativization. Studies in Second Language Acquisition, 13, 431-69.

DOUGHTY, Catherine e WILLIAMS, Jessica (orgs.) (1998). Focus on Form in Classroom Second Language Acquisition. Cambridge University Press, New York.

ELLIS, Rod (1997). The Study of Second Language Acquisition. Oxford University Press, Oxford.

FIORIN, José Luiz (2003) "Pragmática". In: FIORIN, José Luiz (org) Introdução à Linguística II. Contexto, São Paulo.

(1996). As astúcias da enunciação. Ática, São Paulo.

GASS, Susan (1997). Input, interaction, and the second language learner. Lawrence Erlbaum Associates, Mahwah.

HARLIG, Kathleen Bardovi (2000). Tense and aspect in second language acquisition: form, meaning and use. Blackweel, Michigan.

KRASHEN, Stephen (1982). "Second Language acquisition Theory". In: Principles and Practice in Second Language Acquisition. Pergamon Press, Oxford, p. 9-56.

(1985). The Input Hypothesis. Longman, London. 
LONG, Michael $\mathrm{H}$. "The role of the linguistic environment in second language acquisition". In: RITCHIE e BHATIA (eds) (1996). Handbook of second langiage acquisition. NY: Academic Press.

"The role of linguistic environment in second language acquisition". In: LUISE, Maria Cecilia (2006). Italiano come lingua seconda. Utet, Novara.

MACKEY, Alison e GASS, Susan (2005). Second Language Research. Methodology and Design. Lawrence Erlbaum, New Jersey.

MEZZADRI, Marco (2003). I ferri del mestiere. Guerra Edizioni, Perugia.

MORETTI, Battista G. \& ORVIETTO, Giorgio R. (1984). Il verbo Grammatica italiana. Bernucci, Perugia, vol I.

NUNAN David (1992). Research Methods in Language Learning. Cambridge University Press, New York.

PALLOTTI, Gabriele (1998). La seconda lingua. Bompiani, Milão.

RAMAT, Anna Giacalone (a cura di) (2003). Verso l'italiano. Carocci, Roma.

RASTELLI, Stefano (2009). Che cos'è la didattica acquisizionale. Carocci, Roma.

RICHARDS, Jack C. e RODGERS, Theodore S. (2001). Approaches and Methods in Language Teaching. 2nd ed. Cambridge University Press, New York.

ROBINSON, Peter (1996). Learning simple and complex second language rules under implicit, incidental, rule-search, and instructed conditions. Studies in Second Language Acquisition, 18, 27-67.

(1997). Generalizability and automaticity of second language learning under implicit, incidental, enhanced, and instructed conditions. Studies in Second Language Acquisition, 19, 223-47.

ROSI, Fabiana (2008). Le categorie tempo-aspettuali dell'italiano in prospettiva acquisizionale. In: COSTAMAGNA, Lidia e SCAGLIONE, Stefania. Italiano acquisizione e perdita. Francoangeli, Milano, p. 53-85.

SWAIN, Merrill (1985). "Communicative competence: Some Roles of Comprehensible Input and Comprehensible Output in its Development". In GASS, Susan \& MADDEN, Carolyn (orgs). Input in Second Language Acquisition. Newbury House, Rowley, p. 235-253. 
(2005). "The Output Hypothesis: Theory and Research". In: Hinkel, Eli (org.) Handbook of Research in Second Language Teaching and Learning. NJ: Lawrence Erlbaum Associates, Mahwah, p. 471-483.

SEMPLICI, Stefania (2010). Modelli operativi di anlisi di materilai didattici. In: DIADORI, Pierangela (org) Insegnare italiano a stranieri. Mondadori, Milano, p. 201231.

SANTORO, Elisabetta (2007). Da indissociabilidade entre o ensino de língua e de literatura: uma proposta para o ensino do italiano como língua estrangeira em cursos de Letras. Tese de doutorado defendida junto ao DL (FFLCH/USP). Disponível em: http://www.teses.usp.br/teses/disponiveis/8/8139/tde-26022008-141241.

(2006). Il tempo e la lingua: raccontare in italiano. Civiltà italiana. Pubblicazioni dell'Associazione Internazionale dei Professori di Italiano (Atti de XVII Congresso AIPI, Ascoli Piceno 22-26 agosto 2006). Tempo e memoria nella lingua e letteratura italiana. Vol. I, numero fuori serie. Disponível em: http://www.infoaipi.org/attion/ascoli_vol_1.pdf.

SERIANNI, Luca (1997). Italiano. Grammatica, sintassi, dubbi. Garzanti, Milano.

Milano.

(2001). La grammatica della lingua italiana. Mondadori,

TARONE Elaine E.; GASS, Susan M. e COHEN, Andrew D. (1994). Research Methodology in Second Language Acquisition. Lawrence Erlbaum, New Jersey.

VENDLER, Zeno (1967). Linguistics in Philosophy. Cornell University Press, New York. 
Anexos - Anexo 1

\section{Atividade utilizada para a pesquisa}

\section{1ª parte: FILME E PRODUÇÃO ESCRITA}

IO NON HO PAURA (Gabriele Salvatores, Italia, 2003)

Era un'estate molto calda del 1978 e i ragazzini di un piccolo paesino erano in vacanza. Si aggiravano fra le case e la campagna. Durante una di queste gite il piccolo Michele, nove anni, fa una scoperta sconvolgente: gli adulti del paesino avevano sequestrato un bambino e l'avevano nascosto nel pozzo di una casa abbandonata. Michele non comprende quella situazione e cerca di capirla nei dettagli. Piano piano attraverso la TV, le visite al bambino sequestrato e l'osservazione che fa della famiglia, si rende conto che anche i suoi genitori fanno parte del rapimento.

Dopo aver visto due volte lo spezzone del film, prova a raccontare cosa è successo. Possono aiutarti le parole indicate del riquadro qui sotto.

Verbi: vedere, guardare, camminare, sentire, scoprire, cercare, esserci, lanciare, continuare, trovare, comparire, cadere, pedalare, camminare, aprire, arrivare.

Altre parole utili: campo di grano, bicicletta, buco, uccelli, pietre, formiche, occhi, maiali.

Comincia così...

Era estate. Faceva molto caldo. Michele andava in bicicletta quando 


\section{2ª parte: CLOZE}

Dopo aver fatto un viaggio in Brasile nel 2004, Cristina Fenu ha scritto un diario in cui prova a raccontarlo.

Completa il testo utilizzando i verbi tra parentesi.

Nell'estate del 2004 (partire - io) da Roma e dopo uno scalo a Parigi, (arrivare - io) a Rio de Janeiro di sera, da sola, mio cugino sarebbe arrivato il giorno dopo da New York. Mentre l'aereo (sorvolare) la città, (sentirsi - io) molto piccola e (provare - io) un po' di inquietudine, non (riuscire - io) a vedere la fine delle migliaia di luci

della città...

In molti mi avevano spaventato sulla pericolosità di questo viaggio e sui rischi che avrei corso arrivando in una metropoli del genere per la prima volta da sola e senza conoscere la lingua. (prendere - io) un taxi e subito (mettermi - io) a parlare con il conducente, un uomo di mezza età, molto simpatico, io (parlare) in spagnolo e lui in portoghese e (capirsi - noi), non so come...

Avevo prenotato un ostello a Copacabana e (esserci) un piccolo imprevisto.... (esserci) una festa in piazza proprio davanti l'ostello, ottimo benvenuto. (trovare - io) la città sensazionale, (visitare - noi) il Pao Azucar, il Cristo Redentor,

Copacabana, Ipanema, il quartiere di Santa Teresa, questi sono stati i primi 2 giorni.

La vita notturna a Copacabana (essere) un po' dispersiva. (...)

La seconda serata (preferire - noi) restare in piazza dato che la festa (durare) 3 giorni !

http://www.viaggiareliberi.it/brasile 2004 cristina.htm, accesso: 25/04/2010. 
Anexo 2

\section{PARA A PESQUISA PRECISAMOS DE ALGUNS DADOS... AGRADECEMOS SUA COLABORAÇÃO!}

Idade:

Profissão:

Grau de escolaridade:

Idiomas que fala:

Há quanto tempo estuda Italiano no Italiano no Campus:

Já estudou Italiano em outra época e parou? Se sim, quando e onde? Por quanto tempo?

É de origem italiana?

Já foi para a Itália? Se sim, quando e por quanto tempo ficou?

Por que estuda a língua?

Tem contato com a língua fora do período de aula? Se sim, onde?

Lê jornais, livros, escuta músicas fora do período de aula? 